\title{
PRODUCTION AND INDIFFERENCE PRICING OF TRANSURANIUM ISOTOPES
}

D. E. DEONICI

E. A. ESCHBACH

MARCH, 1966

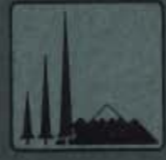

\section{BattelleN NoRthWEst}

BATTELLE MEMORIAL INSTITUTE / PACIFIC NORTHWEST LABORATORY 


\section{LEGAL NOTICE}

This report was prepared as an account of Government sponsored work. Neither the United States, nor the Commission, nor any person acting on behalf of the Commission:

A. Makes any warranty or representation, expressed or implied, with respect to the accuracy, completeness, or usefulness of the information contained in this report, or that the use of any information, apparatus, method, or process disclosed in this report may not infringe privately owned rights; or

B. Assumes any liabilities with respect to the use of, or for damages resulting from the use of any information, apparatus, method, or process disclosed in this report.

As used in the above, "person acting on behalf of the Commission" includes any employee or contractor of the Commission, or employee of such contractor, to the extent that such employee or contractor of the Commission, or employee of such contractor prepares, disseminates, or provides access to, any information pursuant to his employment or contract with the Commission, or his employment with such contractor.

\section{PACIFIC NORTHWEST LABORATORY}

RICHLAND, WASHINGTON

operated by

BATTELLE MEMORIAL INSTITUTE

for the

UNITED STATES ATOMIC ENERGY COMMISSION UNDER CONTRACT AT(45-1)-1830 
BNWL -223

UC-80, Reactor Technology

\author{
PRODUCTION AND INDIFFERENCE PRICING \\ OF TRANSURANIUM ISOTOPES
}

By

D. E. Deonigi

E. A. Eschbach

Advanced Concepts and Analys is Section

Mathematics Department

\author{
March, 1966
}

mistribution made JUN 2966

PACIFIC NORTHWEST LABORATORY

RICHLAND, WASH INGTON 
Printed In USA. Price $\$ 3.00$. Available from the Clearinghouse for Federal Scientific and Technical Information Nationa1 Bureau of Standards

U.S. Department of Commerce Springfield, Virginia 
BNWL -223

\section{ABSTRAC'T}

This report indicates the computed rates at which $\mathrm{Np}^{237}$, $\mathrm{Pu}^{238}, \mathrm{Am}^{241}, \mathrm{Cm}^{242}$ and $\mathrm{Cm}^{244}$ are incidentally produced by simulated power reactors. Also shown is the extent to which some power reactor fueling methods can be altered to increase the production and purity of $\mathrm{Pu}^{238}$ and $\mathrm{Cm}^{244}$. An explanation of the indifference price concept is introduced in order to assess the effect of various $\mathrm{Pu} 238$ and $\mathrm{Cm}^{244}$ credits on the equitable price of the precursor, or target, isotopes. Other calculations in this study show how various credits for transuranium isotopes would affect fuel-cycle costs both for normal fueling methods: and for some altered fueling methods in power reactors. 
. 


\section{TABLE OF CONTENTS}

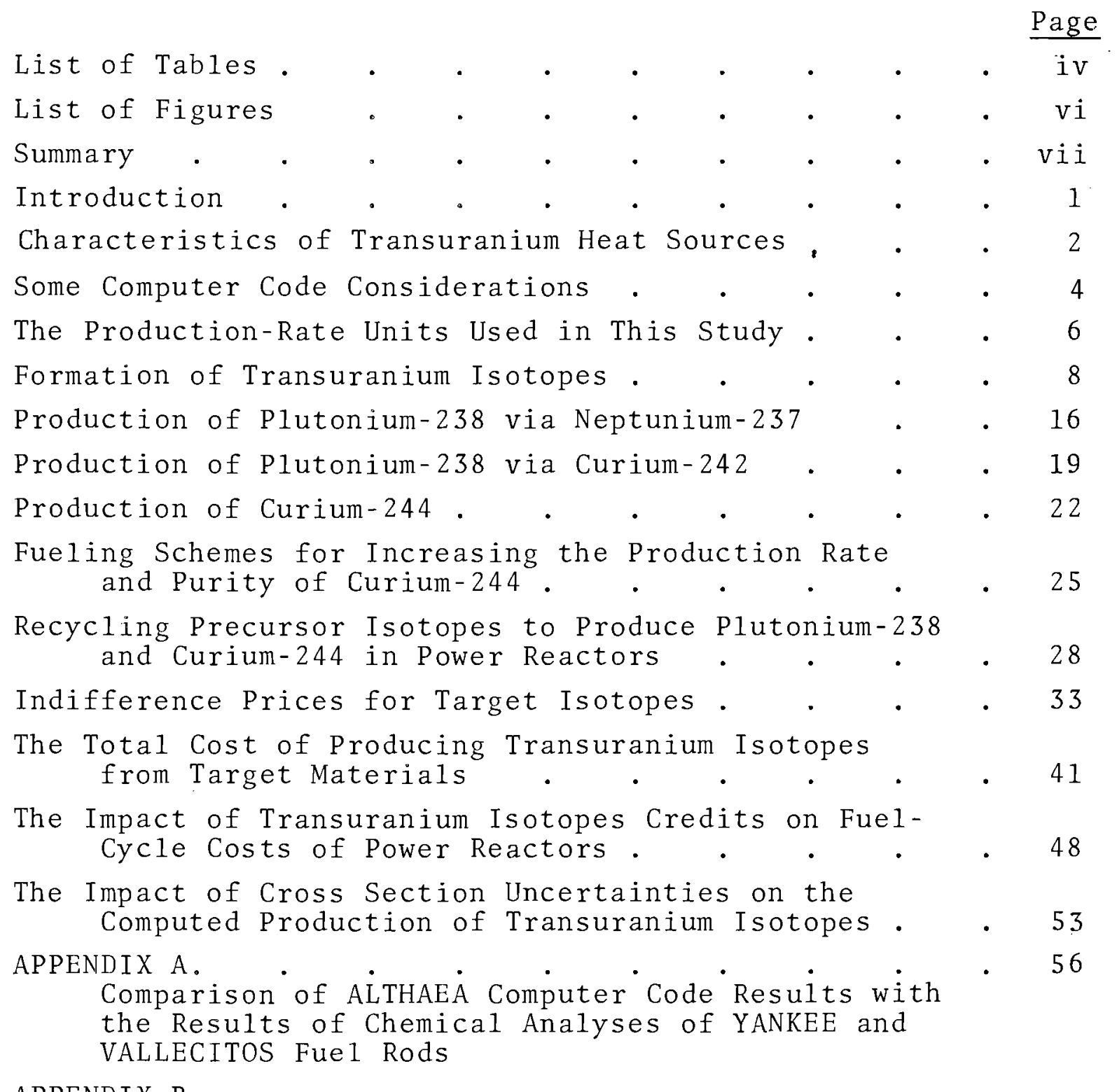

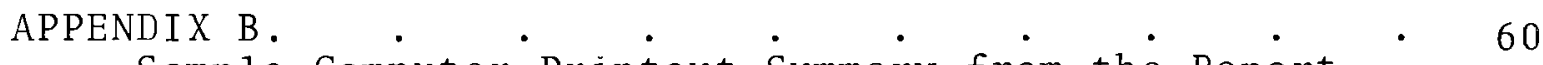
Sample Computer Printout Summary from the Report Entitled Formation of Transuranium Isotopes in Power Reactors, BNWL-140 REVI

References. 


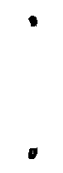




\section{LIST OF TABLES}

$\underline{\text { Table }}$

$\underline{\text { Page }}$

Summary The Effect of Transuranium Isotope Credits

Table I on the Fuel-Cycle Cost for Normal Power Reactor Fueling Methods

viii

Summary Production of Transuranium Isotopes in Table I P Power Reactors

$\mathrm{X}$

Characteristics of Attractive Radioisotopic Heat Sources

I The Computed Production and Purity of $\mathrm{Cm}^{244}$ From Plutonium Enriched Natural Uranium Fue 1 at Constant Power or at Constant Flux

II Some Isotope Properties

IV Relative Power (W/MWe-yr) Successively Generated by a Curium Mixture Initially Containing 86 wt: $\mathrm{Cm}^{244}$.

$\mathrm{V} \quad$ Recycle of Plutonium and Americium to Form $\mathrm{Cm}^{2} 42, \mathrm{Cm} 244$, and $\mathrm{Pu} 238$ in a PWR Using Slightly Enriched Uranium as Supplemental Enrichment

VI Recycle of $\mathrm{U}^{236}$ and $\mathrm{Np}^{237}$ to Form $\mathrm{Pu}^{238}$ in a PWR Using Slightly Enriched Uranium

VII Recycle of $\mathrm{U}^{236}$ and $\mathrm{Np}^{237}$ to Form $\mathrm{Pu}^{238}$ in a PWR Using Ful1y Enriched Uranium

VII Targets and Target Concentrations Used for Determining the Indifference Prices of Isotopes Leading to $\mathrm{Cm}^{24} 4$

IX Heat Generated by $\mathrm{Cm}^{242}$ Produced during the Irradiation of a Target Containing Am241

$X \quad$ The Effect of Transuranium Isotope Credits on the Fue1-Cycle Cost for Normal Power Reactor Fueling Methods

XI The Effect of Transuranium Isotope Credits on Power Reactor Fue1-Cycle Costs When Normal Fueling Methods Have Been Altered to Increase the Production of Transuranium Isotopes

XII The Effect of Varied Nuclear Properties on Isotopic Concentrations at Discharge 


\section{LIST OF TABLES (Contd.)}

Table

$\underline{\text { Page }}$

A-I ALTHAEA Burnup Results Compared with Chemical Analysis of Yankee Fuel Rods 57

A-II ALTHAEA Burnup Results Compared with Chemical Analysis of Vallecitos Fuel Rods 


\section{LIST OF FIGURES}

Figure

$\underline{\text { Page }}$

1

Heat Production of Four Transuranium Isotopes

2 Principal Nuclear Reactions for Higher Isotopes Produced at Typical Power-Reactor Flux Levels

3 Isotope Production as a Function of Fue1

Exposure in a Simulated Pressurized Water

Reactor

$\mathrm{Np}^{237}$ Production for Various F1ux Ratios

$\mathrm{Np}^{237}$ Production for Various $\mathrm{U}^{238}$ Densities

in a Simulated Water Reactor

$\mathrm{Cm}^{244}$ Production for Various F1ux Ratios and Neutron Temperatures

$\mathrm{Cm}^{244}$ Production (in a PWR) for Various Plutonium Compositions in Natural Uranium

$\mathrm{Cm}^{244}$ Production From Various Fueling Schemes

in a Simulated Water Reactor

$\mathrm{Cm}^{244}$ Purities Obtained From Various Fueling

Schemes in a Simulated Water Reactor

Indifference Price of $\mathrm{Np}^{237}$ for a Given $\mathrm{Pu}^{238}$

Price

11 Target Indifference Prices as a Function of $\mathrm{Cm}^{24} 4$ Credit

12 Target Indifference Prices as a Function of $\mathrm{Pu} 238$ Credit

Indifference Price of $\mathrm{Am}^{241}$ as a Function of $\mathrm{Pu}^{238}$ Credit

14 The Effect of Processing Costs on the Indifference Price of $\mathrm{Np} 237$ Produced in a Simulated Water Reactor

15 The $\mathrm{Np}^{237}$ Target Depletion and the $\mathrm{Pu}^{238}$ Product Formation in a Simulated Water Reactor at a F1ux Level of $2 \times 10^{13}$ neutrons $\mathrm{cm}^{-2} \mathrm{sec}^{-1}$ 


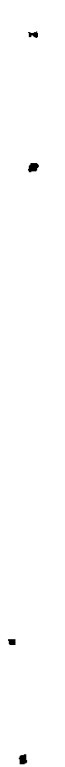

. 


\section{$\underline{\text { SUMMARY }}$}

Today power reactors incidentally produce separable quantities of the transuranium isotopes $\mathrm{Np}^{237}$, americium, and curium during fuel burnups. These by-products are not being recovered because their value is not enough to reduce fuel-cycle costs. But if a market is created for transuranium heat-source isotopes, such as $\mathrm{Pu}^{238}$ or $\mathrm{Cm}^{244}$, recovery of these by-products for sale or for use as target materials would reduce fuel-cycle costs.

The fuel-cycle costs when transuranium isotopes are not recovered are given in Case No. 1 of Summary Table I for four, "normal" power-reactor fueling methods. Some idea of the fuelcycle cost reductions when transuranium isotopes are recovered can be obtained from the other cases in Summary Table I. In Case No. 3, for example, one can see that if $\mathrm{Np}^{237}$, and it alone, is worth $\$ 100 / \mathrm{g}$ net, the fuel-cycle cost reduction both of a Boiling Water Reactor (BWR)*burning slightly enriched uranium and of a Pressurized Water Reactor (PWR) *burning plutonium-enriched natural uranium would be about $0.1 \mathrm{mill} / \mathrm{kWhe}$. For a 1000 MWe power reactor, this 0.1 mill reduction would amount to an annual saving of about $\$ 750,000$. Case No. 3 also shows that a PWR burning slightly enriched uranium and a PWR recycling the plutonium formed in a previous uranium cycle would have fuel-cycle cost reductions of 0.141 and $0.161 \mathrm{mills} / \mathrm{kWhe}$ respectively, if $\mathrm{Np}^{237}$, and it alone, has a net worth of $\$ 100 / \mathrm{g}$.

Case No. 9 in Summary Table I shows that a PWR burning slightly enriched uranium would have a $0.1 \mathrm{mill} / \mathrm{kWh}$ reduction if $\mathrm{Am}^{243}$ is worth $\$ 100 / \mathrm{g}$ and $\mathrm{Cm}^{244}$ is worth $\$ 500 / \mathrm{g}$. However, if plutonium is recycled, only a $\mathrm{Cm}^{244}$ credit of $\$ 250$ would be required to obtain a $0.1 \mathrm{mi} 11 / \mathrm{kWhe}$ reduction. (See Case No. 10 in the PWR-Pu column of Summary Table I.)

*Although this report presents data for PWR and BWR designs, it should be noted that these designs are continually changing. Consequently, the data in this report apply to a particular stage in the evolution of power reactors (the 1000 MWe reference designs of the year 1963). 
SUMMARY TABLE I

THE EFFECT OF TRANSURANTUM ISOTOPE CREDITS ON THE FUEL-CYCLE COST FOR NORMAI POWER REACTOR FUELING METHODS

\begin{tabular}{|c|c|c|c|c|c|c|c|c|c|c|c|c|c|}
\hline \multirow[b]{2}{*}{$\begin{array}{l}\text { Case } \\
\text { No. }\end{array}$} & \multicolumn{9}{|c|}{ Isotope Credit, $\$ / \mathrm{g}^{(\mathrm{a})}$} & \multicolumn{4}{|c|}{ Fuel Cycle Cost Reduction, (b) Mills $/ \mathrm{kWh}$} \\
\hline & $\underline{\mathrm{Np}}^{237}$ & $\mathrm{Pu}^{239}$ & $\mathrm{Pu}^{240}$ & $\mathrm{Pu}^{241}$ & $\mathrm{Pu}^{242}$ & $\mathrm{Am}^{241}$ & $\mathrm{Am}^{243}$ & $\mathrm{Cm}^{242}$ & $\mathrm{Cm}^{244}$ & $\mathrm{BWR}^{(\mathrm{c})}$ & $\mathrm{PWR}^{(\mathrm{c})}$ & $\begin{array}{l}\text { PWR } \\
\text { Plutonium } \\
\text { Pluto }\end{array}$ & $\begin{array}{l}\text { PWR (e) } \\
\text { Pu-Nat. }\end{array}$ \\
\hline & & & & & & & & & & $2.165^{(g)}$ & $1.885(\mathrm{~g})$ & $1.885(\mathrm{~g})$ & $1.885^{(\mathrm{g})}$ \\
\hline 1 & 0 & $10^{(f)}$ & 0 & $10^{(f)}$ & 0 & 0 & 0 & 0 & 0 & -0.000 & -0.000 & -0.000 & -0.000 \\
\hline 2 & 150 & 10 & 0 & 10 & O & 0 & O & 0 & 0 & -0.147 & -0.212 & -0.187 & -0.144 \\
\hline 3 & 100 & 10 & 0 & 10 & 0 & 0 & 0 & 0 & 0 & -0.098 & -0.141 & -0.161 & -0.095 \\
\hline 4 & 50 & 10 & 0 & 10 & 0 & 0 & 0 & 0 & 0 & -0.049 & -0.070 & -0.081 & -0.047 \\
\hline 5 & 0 & 10 & 0 & 10 & 0 & 150 & 0 & 400 & 0 & -0.042 & -0.046 & -0.094 & -0.300 \\
\hline 6 & 0 & 10 & 0 & 10 & 0 & 50 & 0 & 200 & 0 & -0.016 & -0.019 & -0.038 & -0.124 \\
\hline 7 & 0 & 10 & 0 & 10 & 0 & 0 & 0 & 100 & 0 & -0.004 & -0.005 & -0.011 & -0.038 \\
\hline 8 & 0 & 10 & 0 & 10 & 0 & 0 & 300 & 0 & 1000 & -0.110 & -0.217 & -0.656 & -1.497 \\
\hline 9 & 0 & 10 & 0 & 10 & 0 & 0 & 100 & 0 & 500 & -0.243 & -0.105 & -0.285 & -0.687 \\
\hline 10 & 0 & 10 & 0 & 10 & 0 & 0 & 0 & 0 & 250 & -0.011 & -0.025 & -0.100 & -0.290 \\
\hline 11 & 150 & 10 & 0 & 10 & 0 & 150 & 300 & 400 & 1000 & -0.295 & -0.468 & -0.980 & -1.886 \\
\hline 12 & 50 & 10 & 0 & 10 & 0 & 50 & 100 & 200 & 500 & -0.108 & -0.174 & -0.400 & -0.845 \\
\hline 13 & 0 & 10 & 0 & 10 & 0 & 0 & 0 & 100 & 250 & -0.015 & -0.030 & -0.110 & -0.327 \\
\hline 14 & 150 & 10 & 0 & 20 & 100 & 150 & 300 & 400 & 1000 & -0.428 & -0.658 & -1.197 & -1.777 \\
\hline 15 & 50 & 10 & 0 & 15 & 50 & 50 & 100 & 200 & 500 & -0.172 & -0.251 & -0.505 & -0.793 \\
\hline
\end{tabular}

(a) All credits given for the preceding isotopes of a transuranium heat source are target indifference prices. (See Page 33.)

b) The fuel exposure has been optimized for each set of isotope credits, with a fabrication cost of $\$ 100 / \mathrm{kg}$ uranium, a reprocessing cost of $\$ 24 / \mathrm{kg}$ uranium, a shipping cost of $\$ 6.50 / \mathrm{kg}$, a thermal-to-electrical conversion of $31 \%$, and a working capital interest rate of $10 \% / y x$ (private ownership assumed).

(c) Pressurized water reactor fueled with slightly enriched uranium.

(d) Pressurized water reactor recycling the plutonium formed in a previous uranium cycle. Initial composition is $63 \%$ $\mathrm{Pu}-239,23 \% \mathrm{Pu}-2+0,11 \% \mathrm{Pu}-241$, and $3 \% \mathrm{Pu}-2+2$.

(e) Pressurized vater reactor fueled with plutonium enriched natural uranium.

(f) Value of $\mathrm{Pu}-239$ and $\mathrm{Pu}-2^{4} \mathrm{I}$ as heat producers in thermal reactors.

(g) This value is in mills/kWhe and represents the fuel-cycle cost for Case No. 1. 
Transuranium isotope production rates-measured in grams per installed MWe capacity per year (g/MWe-yr)* - are given in Summary Table I for seven different fueling schemes. Of these seven, the first three are "normal" fueling schemes; the other four are special fueling methods that would greatly increase the production of transuranium isotopes. But unless transuranium isotopes are worth between $\$ 500$ and $\$ 1000$ per gram, the fuel-cycle costs of these four fueling schemes will not be competitive with those of the first three.

of the "norma1" fueling schemes, Case 2 has less $\mathrm{Np}^{237}$ production than Case 1 because some of the $U^{235}$ enrichment is replaced with plutonium $\left(\mathrm{Pu}^{239}, \mathrm{Pu}^{240}, \mathrm{Pu}^{241}\right.$, and $\left.\mathrm{Pu}^{242}\right)$ recycled from Case 1 . This plutonium enrichment also accounts for the increased production of $\mathrm{Pu}^{238}, \mathrm{Am}^{243}$, and $\mathrm{Cm}^{244}$. Case 3 has a still lower $\mathrm{Np}^{237}$ production because the $\mathrm{U}^{235}$ is reduced to on $1 \mathrm{y}$ that contained in natural uranium. It should be noted that the $\mathrm{Np}^{237}$ formed in Case 3 is mostly due to the $\mathrm{n}-2 \mathrm{n}$ reaction of $\mathrm{U} 238$. And as in Case 2, so in Case 3, the higher plutonium enrichment accounts for the higher production of $\mathrm{Pu}^{238}, \mathrm{Am}^{243}$, and $\mathrm{Cm}^{244}$.

of the special fueling schemes, Case 7 would produce the most $\mathrm{Np}^{237}$ and $\mathrm{Pu}^{238}$, and Case 5 would produce the most $\mathrm{Am}^{243}$ and $\mathrm{Cm}^{244}$.

The estimated kilograms of transuranium isotopes to be produced in 1970 and 1975 by each of the seven fueling schemes are also indicated in Summary Table II. These estimated production amounts are based on the AEC revised estimate of a total installed capacity of 6500 Mwe for 1970 and 29,000 Mwe for 1975.** It should be noted that the estimated amounts to be produced in 1970 and 1975 wi11 not be available until 1 to 3 years later.

* If applied to a 1000 MWe reactor, a production rate of g/MWe-yr would equal $\mathrm{kg} / \mathrm{yr}$.

* * USAEC Analysis of Advanced Converters and Self-Sustaining Breeders, Washington D.C., March 1965. 
SUMMARY TABLE II

THE PRODUCTION OF TRANSURANIUM ISOTOPES IN POWER REACTORS

$$
\text { (Fuel Exposure is } 24 \mathrm{Mwd} / \mathrm{kg} \text { ) }
$$

\begin{tabular}{|c|c|c|c|c|c|c|c|c|c|c|c|c|c|}
\hline \multirow[b]{2}{*}{$\begin{array}{l}\text { Case } \\
\text { No. }\end{array}$} & & \multicolumn{4}{|c|}{ Production Rates, g/MWe-yr ${ }^{(1)}$} & \multicolumn{4}{|c|}{$\begin{array}{l}\text { Estimated Annuel Production } \\
\text { in 1970, Kilograms }(2)\end{array}$} & \multicolumn{4}{|c|}{$\begin{array}{l}\text { Estimated Annual Production in } \\
1975 \text {, Kilograms }\end{array}$} \\
\hline & Fueling Scheme & $\mathrm{Np}^{237}$ & $\mathrm{Pu}^{238^{(4)}}$ & $\mathrm{An}^{243}$ & $\mathrm{Cm}^{244}$ & $\mathrm{~Np}^{237}$ & $\mathrm{Pu} \mathrm{u}^{238^{(4)}}$ & $\mathrm{Am}^{243}$ & $\mathrm{Cm}^{244}$ & $\mathrm{~Np}^{237}$ & $\mathrm{Pu}^{238^{(4)}}$ & $\mathrm{Am}^{243}$ & $\mathrm{Cm}^{244}$ \\
\hline$\frac{1}{2}$ & $\begin{array}{l}\text { Slightly Enriched Uranium } \\
\text { Slightly Enriched Uranium, w }\end{array}$ & 27.2 & 0.18 & 2.25 & 0.44 & 111.8 & 1.2 & 14.6 & 2.9 & 498.8 & 5.2 & 70.5 & \\
\hline & $\operatorname{Rec}$ & 24.5 & 0.55 & 11.40 & 3.90 & 94.2 & 3.6 & 74.1 & 25.3 & 420 & 15 & 330.6 & 113.1 \\
\hline 3 & $\begin{array}{l}\text { Plutonium in Natural Uranium (6) } \\
\text { Slightly Enriched Uranium, with, Pfutonium, }\end{array}$ & 5.6 & 1.23 & 24.70 & 7.59 & 36.4 & 8 & 160.5 & 49.3 & 162 & 35.7 & 716.3 & \\
\hline & Americiu & 27.2 & 0.6 & 12.20 & 4.8 & 176.8 & 4.2 & 79.3 & 31 & 778.8 & 18.6 & 353.8 & \\
\hline 5 & Plutonium in Zirconium & 0.4 & $2.00(9$ & 65.90 & 51.73 & 2.6 & 13.0 & 428.3 & 336.2 & 11.06 & 58.0 & 1911.1 & 150 \\
\hline 5 & Fully Enriched U-235 in Zirconium & $\begin{array}{l}48.8 \\
68.7\end{array}$ & $\begin{array}{l}24.07(10) \\
32.07(10)\end{array}$ & 1.70 & $\begin{array}{l}2.30 \\
1.98\end{array}$ & $\begin{array}{r}317.2 \\
446.5\end{array}$ & $\begin{array}{l}156.5 \\
214.3\end{array}$ & 11.1 & 14.9 & $\begin{array}{r}1415.2 \\
1992.3\end{array}$ & $\begin{array}{l}698.0 \\
956.2\end{array}$ & $\begin{array}{l}43.3 \\
50.2\end{array}$ & $\begin{array}{l}66.7 \\
57.4\end{array}$ \\
\hline
\end{tabular}

(1) The load factor is $80 \%$, the thermal-to-electrical efficiency is 0.33 , the time perlod is one year after fuel discharge, and the amount lost

(2) Eased on the AEC revised estimate of a total installed capacity of 6500 MWe (USAEC ANALYSIS OF ADVANCED CONVERTERS AND SELF-SUSTAINING BREEDERS, Washington, D. C., March 1906).

(3) Based on the AEC revised estimate of a total installed capacity of 29,000 MW (USAEC ANALYSIS OF ADVANCED CONVERTERS AND SELF-SUSTAINING

(4) The Pu-238 1 s produced by alpha decay of $\mathrm{Cm}-242$, and normally has a purity $[\mathrm{Pu}-238 /(\mathrm{Pu}-238+\mathrm{Pu}-240)]$ greater than $80 \%$.

(5) The plutonium recycled comes from Case No. 1

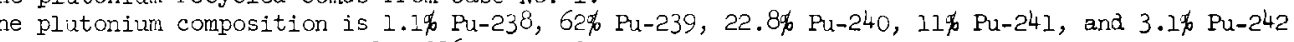

The plutonium, americium, and U-236 recycled come from Case No. 1.

(8) The U-236 recycled cones

(10) The the 
At the present time, the design and fueling of power reactors tend to minimize the alpha $\left(\sigma_{\mathrm{c}} / \sigma_{f}\right)$ of $\mathrm{U}^{235}, \mathrm{Pu}^{239}$, and $\mathrm{Pu}^{241}$. The reason for minimizing these alphas is to maximize the generation of heat and to minimize the production of the two parasites $\mathrm{U}^{236}$ and $\mathrm{Pu}^{242}$ per gram of $\mathrm{U}^{235}$ or fissile plutonium destroyed. However, if there were a market for $\mathrm{U}^{236}$ and $\mathrm{Pu}^{242}$ as precursors to $\mathrm{Pu}^{238}$ and $\mathrm{Cm}^{244}$, respectively, it might be economical to alter the reactor fueling system so as to obtain a higher value of alpha for $\mathrm{U}^{235}, \mathrm{Pu}^{239}$, and $\mathrm{Pu}^{241}$. Furthermore, if there were a sudden market for transuranium heat-source isotopes, a short term windfall situation would be created for those holding $\mathrm{U}^{236}$ and $\mathrm{Pu}^{242}$, which at present have no market price.

Although a market for a transuranium heat-source isotope would necessarily create a market price for its precursor isotopes, or target material, this price must be known before there can be an incentive to deliberately irradiate target material in power reactors. This report explains how such a price, which is the equitable price of target material, can be adequately determined (as a first approximation). Briefly, this equitable price is defined as the target indifference price-that is, the amount of money that a reactor operator pays for a target whose product yields an income sufficient to make the fuel-cycle cost of slightly enriched uranium with the target equal to the fuel-cycle cost of the same fuel without the target. The target indifference price is also called the target break-even price, because with either type of fueling method a reactor operator breaks even on his fuel-cycle costs.

This report then shows how various market prices for $\mathrm{Pu}^{238}$ and $\mathrm{Cm}^{244}$ products would change target indifference prices. The effect of processing costs on the indifference price of a special target 1ike $\mathrm{Np}^{237}$ is a1so shown. 
All calculations in this report used the zero-dimensional burnup mode of the ALTHAEA computer code.* Appendix A indicates how well the previous results of ALTHAEA agree with the chemical analyses of Yankee and Vallecitos fuel rods. Since transuranium isotopes are produced in amounts that vary with the alpha of $\mathrm{Pu}^{239}$ and $\mathrm{Pu}{ }^{241}$, and at rates that vary with the resonance integral of americium, curium, $\mathrm{U}^{236}$, and $\mathrm{Np}^{237}$, an error analysis of these alpha and effective cross section values are included in this report.

This report complements the Battelle Northwest Report BNWL-140 REV1,** which consists mostly of computer printout summaries that indicate the yields of transuranium isotopes from 24 different fueling schemes. Appendix B contains a selection from the Battelle Report BNWL-140 REV1. For data on power reactor fission product yields, see the Battelle Northwest report BNWL-244. + For an interesting americium management scheme to increase the power reactor yield of decay isotopes, see Lang's report.tt (See also page 21 below.) In his study, Lang used the ALTHAEA code much the same way as it was used in this study.

* E. T. Merril1, ALTHAEA (to be published), BNWL, Richland, Washington

* D. E. Deonigi. Formation of Transuranium Isotopes in Power Reactors, BNWL-1 40 REV1, January 1966.

+ C. A. Rohrmann, E. T. Merrill, Formation of Selected Fission Products in Power Reactors, BNWL-244, March 1966.

++ L. W. Lang. Management of Americium in Power Reactor Fuels to Optimize production of Alpha-Emitting Isotopes, BNWL-SA-472, January 1966 . 
BNWL -223

\section{INTRODUCTION}

Irradiating reactor fuel produces a wide variety of isotopes besides the classical fuel isotopes (plutonium from $\mathrm{U}^{238}$ and $\mathrm{U}^{233}$ from $\mathrm{Th}^{232}$ ). However, after capturing a neutron, on $1 y \mathrm{Pu}^{239}, \mathrm{Pu}^{241}, \mathrm{U}^{233}$, and $\mathrm{U}^{235}$ can readily fission, producing, in turn, a wide variety of fission products, all of which are well known-because of their parasitic neutron absorption in a reactor and because of their radioactivity (mostly $\beta$ and $\gamma$ )-but only a few of which have the half-life, specific power, and radioactivity suitable for a practical heat device. On the other hand, $\mathrm{Pu}^{239}, \mathrm{Pu}^{241}, \mathrm{U}^{233}$, and $\mathrm{U}^{235}$ do not necessarily fission after capturing a neutron: they sometimes form a new isotope which, after capturing a neutron, can also form a new isotope. Thus some successively heavier atoms are incidentally produced during the irradiation of reactor fuel, and these progeny with an atomic number greater than that of uranium are known as transuranium isotopes.

Some transuranium isotopes have the appropriate combination of half-life, specific power and radioactivity (predominately active alpha particles) to serve as good heat sources. But securing these isotopes from irradiated fuel and, more particularly, arranging fuel cycles in order to increase their production are still very undeveloped technologies.(1) For this reason, the production costs of transuranium heat-source isotopes are high, and only relatively exotic applications (such as in space) can currently justify their use.

In this report no effort has been made to estimate the cost of the special fuel-element encapsulation or separations processes required to produce and recover transuranium heat-source isotopes, the reason being that the future scale of the industry and the likely technology are unknown. In fact, there is still no industrywide agreement on the fabrication costs of normal power-reactor fuel 
elements. It is believed, however, that the associated reactor burnup costs can be computed with some relevance, and this is the task to which the present paper is mainly addressed.

More specifically, this study was undertaken (1) to compute the rate at which $\mathrm{Pu}^{238}$ and $\mathrm{Cm}^{244}$ (as we11 as their preceding isotopes $\mathrm{Np}^{237}, \mathrm{Cm}^{242}, \mathrm{Am}^{241}$, and $\mathrm{Am}^{243}$ ) are incidentally produced by simulated power reactors, (2) to compute the increase in the production rate and purity of $\mathrm{Pu}^{238}$ and $\mathrm{Cm}^{244}$ when normal power reactor fueling methods have been altered, (3) to establish equitable price relationships between the product isotopes $\mathrm{Pu}^{238}$ and $\mathrm{Cm}^{244}$ and their preceding isotopes, or targets, (4) to compute the effect of various transuranium isotope credits on the fuel-cycle costs for normal fueling methods, and (5) to compute the effect of various transuranium isotope credits on the fuel-cycle costs for special fueling methods that increase the power reactor production of transuranium heat sources.

Curium ${ }^{242}$ and $\mathrm{Am}^{241}$ are not the primary isotopes of interest in this study. They enter into the investigation because they are intermediate isotopes to $\mathrm{Pu}^{238}$ and, to a less extent, $\mathrm{Cm}^{244}$. Figure 1 illustrates the reason for the special interest in $\mathrm{Pu}^{238}$ and $\mathrm{Cm}^{244}$ : during the first 5 -year period, the heat generated by $\mathrm{Pu}^{238}$ drops on $1 \mathrm{y} 3 \%$, as against $16 \%$ for $\mathrm{Cm}^{244}$ and $99 \%$ for $\mathrm{Cm}^{242}$; and although the heat produced by $\mathrm{Am}^{241}$ remains nearly constant, this constant level is low. It is interesting to note, however, that the high initial heat output of $\mathrm{Cm}^{242}$ (see Table I) makes it easily comparable to Po 210 in short-period applications (6 months to a year).

\section{CHARACTERISTICS OF TRANSURANIUM HEAT SOURCES}

In common with other isotopic heat sources, the four transuranium isotopes $\mathrm{Pu}^{238}, \mathrm{Cm}^{244}, \mathrm{Cm}^{242}$, and $\mathrm{Am}^{241}$ generate valuable amounts of heat for useful periods of time. Also, their reliability 
Figure 1. HEAT PRODUCTION OF FOUR TRANSURANIUM ISOTOPES

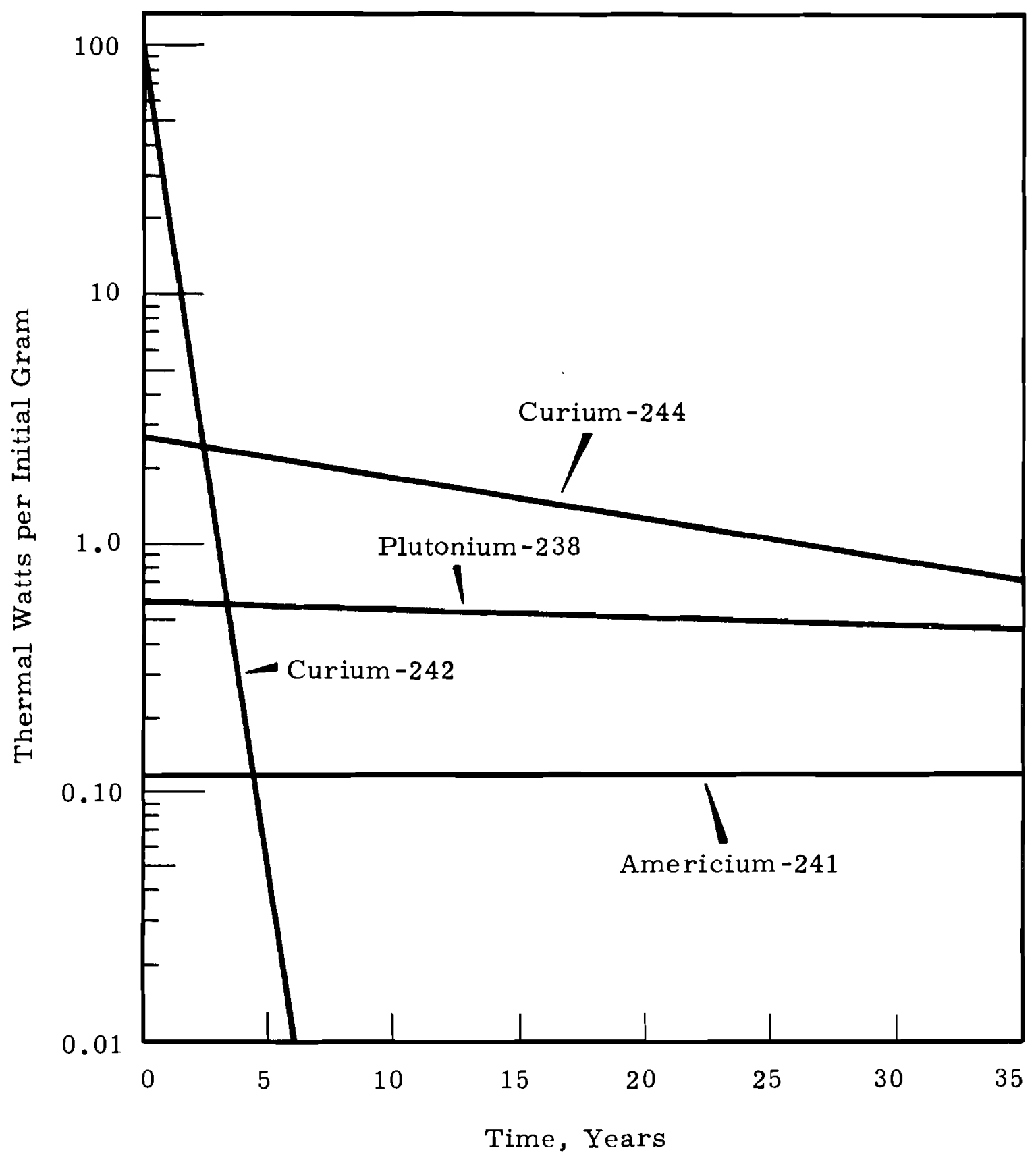


as a power source is unique. Table I indicates the major properties of these four transuranium isotopes and of five other isotopic heat sources.

Plutonium 238 and $\mathrm{Cm}^{244}$ are particularly suitable for use in space or, in other types of remote operation: they both have half-lives that are more than several months but less than a 100 years, their specific heat is not less than 0.1 watt per gram, and the chemical separation of the product and target is economically feasible. (2) As for radiation, $\mathrm{Cm}^{244}$ spontaneously emits 50 times as many neutrons as $\mathrm{Pu}^{238}$, and this may detract from the usefulness of $\mathrm{Cm}^{244}$ as a power source near operating personne1; pure $\mathrm{Pu}^{238^{*}}$ does not have this possible drawback because its radiation is limited mainly to alpha emission, which is easily shielded. But as regards toxicity, $\mathrm{Cm}^{244}$ ranks $20 \mathrm{th}$, whereas $\mathrm{Pu}^{238}$ ranks 6th. (3) Also, $\mathrm{Pu}{ }^{238}$ has a greater critical mass problem than $\mathrm{Cm}^{244}$ : at a density of $10 \mathrm{~g} / \mathrm{cm}^{3}$ the critical mass of $\mathrm{Pu}^{238}$ as an unreflected sphere is about $32 \mathrm{~kg}$, or $18 \mathrm{~kW}$; that of $\mathrm{Cm}^{244}$ is about $58 \mathrm{~kg}$, or $162 \mathrm{~kW}$. (4)

\section{SOME COMPUTER CODE CONSIDERATIONS}

The computer used in this study was an IBM 7090; the computer burnup code was ALTHAEA. (5) The zero-dimensional mode of this code is based on a modified four-group cross section model (employing cross shielding of epithermal resonances) that has been calibrated against many critical and burnup experiments. Appendix A discusses how well the results from ALTHAEA agree with the results of chemical analyses of Yankee and Vallecitos fuels.

Most of the burnup calculations in this study relate to power reactor spectra (water reactors) and to slight deviations from these.

* Pu 238 contaminated with $\mathrm{Pu}^{236}$, which eventually forms Thallium208, can lead to a gamma radiation problem. 
TABLE I ${ }^{(2)}$

CHARACTFRISTICS OF ATLIRACTIVE RADIOISOTOPIC HEAT SOURCES

\begin{tabular}{|c|c|c|c|c|c|c|c|c|c|}
\hline & Cobalt & Strontium $^{90}$ & $\underline{\text { Cesiumin }^{137}}$ & Promethium ${ }^{147}$ & $\underline{\text { Polonium }}^{210}$ & Plutonium $^{238}$ & Americium $^{241}$ & Curium $^{242}$ & Curium $^{244}$ \\
\hline $\begin{array}{l}\text { Specific Power, } \\
\text { watt/g }\end{array}$ & 17.4 & 0.95 & 0.42 & 0.33 & 141 & 0.56 & 0.11 & 120 & 2.8 \\
\hline Half-Life, Yrs. & 5.3 & 28 & $\begin{array}{l}30 \\
35\end{array}$ & 2.7 & 0.38 & 89 & 458 & 0.45 & 18 \\
\hline Isotopic Purity, $\%$ & 10 & 50 & 35 & 95 & 95 & 80 & 90 & 90 & 90 \\
\hline $\begin{array}{l}\text { Compound Form } \\
\text { Density of Compound, }\end{array}$ & ${ }^{\text {Metal }} 8.9$ & $\mathrm{SrTiO}_{4.6}$ & $\begin{array}{l}\text { Glass } \\
3.2\end{array}$ & $\mathrm{Pm}_{6} \mathrm{O}_{3} 6.6$ & Metal 9.3 & $\mathrm{PuO}_{10}$ & $\begin{array}{l}\text { Metal } \\
\quad 11.7\end{array}$ & $\mathrm{Cm}_{2} \mathrm{O}_{31.75}$ & $\begin{array}{l}\mathrm{CmeO}_{3} \\
\quad 11.75\end{array}$ \\
\hline $\begin{array}{l}\mathrm{g} / \mathrm{cm}^{3} \\
\text { Active Isotope in Com- } \\
\text { pound, }{ }^{\prime}\end{array}$ & 10 & 24 & 16 & 82 & 95 & 70 & 90 & 82 & 82 \\
\hline $\begin{array}{l}\text { Specific Power of Com- } \\
\text { pound, Watt/g }\end{array}$ & 1.7 & 0.23 & 0.067 & 0.27 & 134 & 0.39 & 0.1 & 98 & 2.3 \\
\hline $\begin{array}{l}\text { Power Density, Watt } / \mathrm{cm}^{3} \\
\text { of Compound }\end{array}$ & 15.5 & 1.15 & 0.215 & 2.22 & 1210 & 3.9 & 1.17 & 1150 & 27 \\
\hline $\begin{array}{l}\text { Volume for } 2 \mathrm{~kW} \text { Heat, } \\
\mathrm{cm}^{3}\end{array}$ & 129 & 1840 & 9300 & 1120 & 1.65 & 513 & 1710 & $1.7^{4}$ & 74 \\
\hline $\begin{array}{l}\text { Availability } \\
\left.\text { Annual kw-(1967- }{ }^{(a)}\right)\end{array}$ & Available & $\begin{array}{r}\text { Available } \\
(67 \mathrm{~kW})\end{array}$ & $\begin{array}{r}\text { Available } \\
(48 \mathrm{~kW})\end{array}$ & $\begin{array}{r}\text { Available } \\
(11 \mathrm{~kW})\end{array}$ & Available & $\begin{array}{l}\text { Limited } \\
\text { Available }\end{array}$ & $\begin{array}{l}\text { Limited } \\
\text { Production }\end{array}$ & $\begin{array}{l}\text { Potentially } \\
\text { Available }\end{array}$ & $\begin{array}{l}\text { Potentially } \\
\text { Available }\end{array}$ \\
\hline $\begin{array}{l}\text { Shielding Requirernent } \\
\text { Biological Hazard }\end{array}$ & $\begin{array}{l}\text { Heavy } \\
3 \times 10^{-9}\end{array}$ & $3 \times 10^{-10}$ & $\begin{array}{l}\text { Keavy } \\
5 \times 10^{-9}\end{array}$ & $\begin{array}{l}\text { Minor } \\
2 \times 10^{-8}\end{array}$ & $\begin{array}{l}\text { Minor } \\
2 \times 10^{-9}\end{array}$ & $\begin{array}{l}\text { Minor } \\
7 \times 10^{-13}\end{array}$ & $\begin{array}{l}\text { Minor } \\
2 \times 10^{-12}\end{array}$ & $\begin{array}{l}\text { Minor }(b) \\
4 \times 10^{-11}\end{array}$ & $3 \times 10^{-12}$ \\
\hline $\begin{array}{l}\text { Estimateq Gost, } \\
\$ / \text { watt }\end{array}$ & 33 & $19(a)$ & $21(a)$ & $91(a)$ & $26,500(c)$ & 894 & 200 & 17 & 357 \\
\hline Estimated Cost, $\$ / E$ & 570 & $18^{(a)}$ & $9^{(a)}$ & $30^{(a)}$ & 188 & $500^{(c)}$ & 1820 & 2000 & $1000^{(c)}$ \\
\hline $\begin{array}{l}\text { Curies/g } \\
\text { Curies/watt }\end{array}$ & 1130 & 142 & 87 & 914 & 4500 & 17 & 3.25 & 3310 & 84 \\
\hline $\begin{array}{l}\text { Curies/watt } \\
\text { Spontaneous Fission } \\
\text { Half-Life, Yrs. }\end{array}$ & 65 & 150 & 207 & 2770 & 32 & $4.9 \times 10^{10}$ & $1.4 \times 10^{13}$ & $7.2 \times 10^{6}$ & $1.4^{30} \times 10^{7}$ \\
\hline
\end{tabular}

(a) From proposed Hanford Isotope Plant, HW-77770 ( $\mathrm{kW}_{\mathrm{t}}=$ thermal kilowatts).

(b) Except for shielding against neutrons. 
As regards fueling schemes, the zero-dimensional mode of the ALTHAEA code simulated graded fuel management at constant power (per kilogram of fuel) throughout the burnup. Since, however, a constant power burnup does not necessarily apply to a graded scheme, where the flux level would be nearly constant, the validity of the ALTHAEA approximation was checked by calculating the production of $\mathrm{Cm}^{244}$ from several graded fueling schemes at constant power and at constant flux. Table II shows that for plutonium enriched natural uranium fuel there is almost no discrepancy in the production of $\mathrm{Cm}^{244}$, and only a s1ight difference in purity $\left[\mathrm{Cm}^{244} /\left(\mathrm{Cm}^{244}+\mathrm{Cm}^{242}\right)\right.$ at discharge $]$. Because of this verification of the ALTHAEA approximation and because ALTHAEA performs burnup calculations much faster for constant power than for constant flux, the data in this paper are based on constant power burnups for graded fueling schemes.

\section{THE PRODUCTION-RATE UNITS USED IN THIS STUDY}

The isotopic production rates in this study are given in grams per megawatt electrical per year ( $g / \mathrm{MW}_{\mathrm{e}}-\mathrm{yr}$, the capacity factor being $80 \%$ ) as a function of reactivity limited fuel exposure measured in thermal megawatt days per kilogram ( $\left.\mathrm{MWd}_{\mathrm{t}} / \mathrm{kg}\right)$, with the thermal-to-electrical efficiency set at $33 \%$. These units are chosen because they seem to be the most generally used and because they can be easily converted into grams or dollars per year for a given reactor or for a total installed water reactor capacity. The unit g/MWe-yr equals kg/yr for a $1000 \mathrm{MW}$ reactor. To obtain grams per metric ton ( $\mathrm{g} / \mathrm{MT}$ ) or parts per million from a

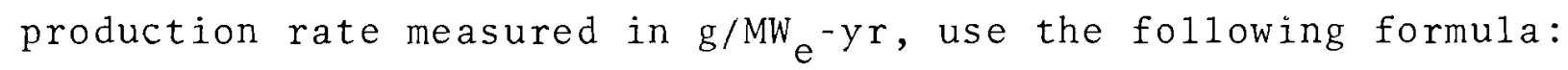

$$
\begin{aligned}
\mathrm{g} / \mathrm{MT}= & \frac{\left(\mathrm{g} / \mathrm{MW}_{\mathrm{e}}-\mathrm{yr}\right)\left(\mathrm{MWd}_{\mathrm{t}} / \mathrm{kg}\right)(1000 \mathrm{~kg} / \mathrm{MT})\left(0.333 \mathrm{MW}_{\mathrm{e}} / \mathrm{MW}_{\mathrm{t}}\right)}{365 \mathrm{days} / \mathrm{yr}} \\
= & \left(\mathrm{g} / \mathrm{MW}_{\mathrm{e}}-\mathrm{yr}, \text { isotopic production rate }\right)\left(\mathrm{MWd}_{\mathrm{t}} / \mathrm{kg},\right. \\
& \text { fue1 exposure })(0.91) .
\end{aligned}
$$




\section{TABLE II}

THE COMPUIED PRODUCTION AND PURLTY OF CURIUM 244 FROM PLUTONIUM ENRICHED NATURAL URANTUM FUEL AT CONSTANT POWER OR AT CONSTANT FLUX

\begin{tabular}{|c|c|c|c|c|}
\hline \multirow{2}{*}{$\begin{array}{l}\text { React Ivity } \\
\text { Ifmited Fue } \\
\text { Exposure, } \\
\text { MWdt/lkg } \\
\end{array}$} & \multicolumn{2}{|c|}{ Constant Power } & \multicolumn{2}{|c|}{ Constant Flux } \\
\hline & $\begin{array}{l}\text { Product 1on, } \\
\mathrm{g} / \mathrm{MW}_{\mathrm{e}} \mathrm{yr}\end{array}$ & $\begin{array}{c}\text { Purity, } \\
\% \\
\end{array}$ & $\begin{array}{l}\text { Production, } \\
\mathrm{g} / \mathrm{MWe}-\mathrm{yr} \\
\end{array}$ & $\begin{array}{c}\text { Purity, } \\
\%\end{array}$ \\
\hline $\begin{array}{l}10.0 \\
18.2 \\
28.3\end{array}$ & $\begin{array}{l}1.37 \\
3.66 \\
7.32\end{array}$ & $\begin{array}{l}49.5 \\
66.1 \\
79.2\end{array}$ & $\begin{array}{l}1.38 \\
3.69 \\
7 \cdot 34\end{array}$ & $\begin{array}{l}50.5 \\
67.8 \\
80.9\end{array}$ \\
\hline
\end{tabular}




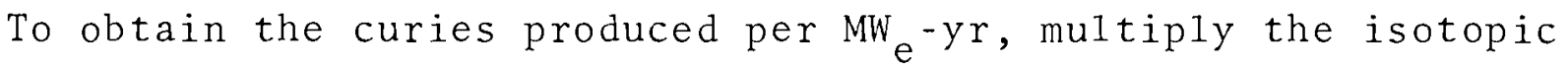
production rate in $\mathrm{g} / \mathrm{MW}$-yr by the number of curies per gram shown in Table $I$ on page 5 .

\section{FORMATION OF TRANSURANIUM ISOTOPES}

Plutonium $238, \mathrm{Cm}^{244}, \mathrm{Cm}^{242}$, and $\mathrm{Am}^{241}$ are formed by a combination of neutron captures, beta decays, and alpha decays. Figure 2 shows the major sequences used by the computer code ALTHAEA to simulate the production of these isotopes. Examination of Figure 2 will show that not all intermediate isotopes are included. The reason: their half-lives are not long enough to appreciably affect the power reactor production of transuranium heat-source isotopes. A typical example is that of $\mathrm{Np}^{238}$. Its elimination from the computer code reduces the power reactor production rate of $\mathrm{Pu}^{238}$ less than $1 \%$ at a normal power reactor flux of $1 \times 10^{13}$ neutrons $\mathrm{cm}^{-2} \mathrm{sec}^{-1}$. And this $1 \%$ error is much smaller than that undoubtedly being caused by the lack of information on the resonance integral of $\mathrm{Pu}^{238}$. Similarly, the errors due to the lack of information on specific parts of the total resonance data for almost all of the transuranium isotopes will far overshadow the small errors caused by the ALTHAEA code omitting some of the intermediate isotopes produced at power reactor flux levels.

Also omitted in the ALTHAEA computer code sequence are some reactions that significantly affect the production of impurities. The $\mathrm{Np}^{237} \mathrm{n}-2 \mathrm{n}$ reaction is one example. This reaction produces $\mathrm{Pu}^{236}$, which always accompanies chemically separated $\mathrm{Pu}{ }^{238}$; and $\mathrm{Pu}^{236}$ (2.85 year half-1ife) alpha-decays into $\mathrm{U}^{232}$ which, after several alpha decays, forms the hard gamma emitter Thallium 208 . Thus for long missions ( 10 years), the gamma activity of $\mathrm{Pu}^{238}$ would be increased from

* At a flux of $1 \times 10^{15}$ neutrons $\mathrm{cm}^{-2} \mathrm{sec}^{-1}$, the error would be $34 \%$. 

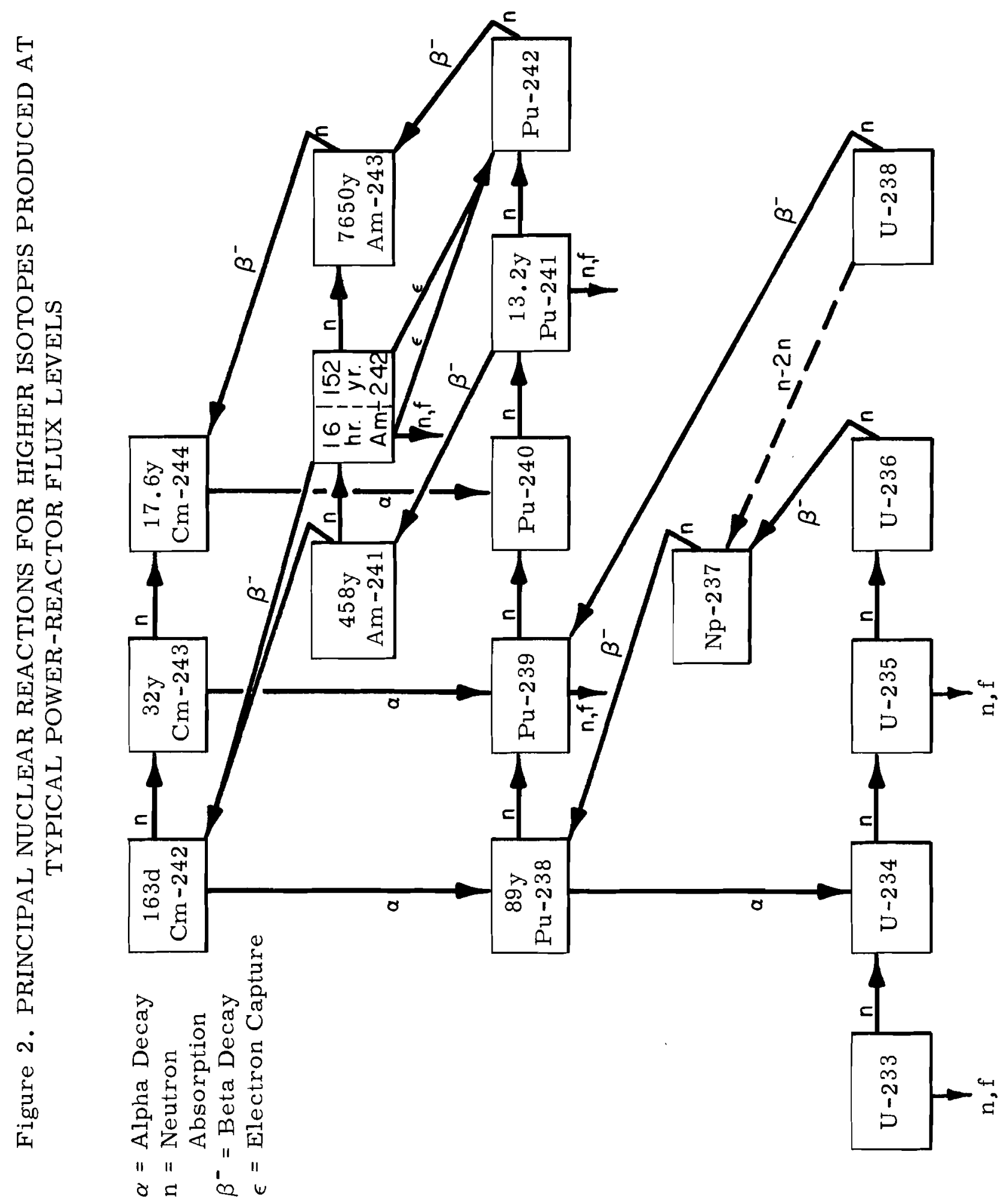
almost nothing to a significant amount. In theory, a computer code should include all those reactions-n-2n's, n-3n's, $\gamma-n^{\prime} s$, etc.,-that significantly affect product purity. But in practice, such computer code coverage can not always be provided, either because too much computer calendar time would be required to account for all the important reactions in the isotopic mishmash of each element under consideration or because the relevant cross section information is lacking. In some cases, therefore, the contamination levels of transuranium isotopes can not be accurately determined except by chemical analysis of discharged fuel.

Figure 2 shows that $\mathrm{Pu}^{238}$ can be formed in two ways- namely, via $\mathrm{Np}^{237}$ or $\mathrm{Am}^{241}$. In one sequence, there are three steps: $\mathrm{U}^{235}$ captures a neutron to form $\mathrm{U}^{236} ; \mathrm{U}^{236}$ captures a neutron to form $\mathrm{Np}^{237}$ ( $\mathrm{Np}^{237}$ is also formed by the $\mathrm{U}^{238} \mathrm{n}-2 \mathrm{n}$ reaction); and $\mathrm{Np}^{237}$ captures a neutron to form reasonably pure (85\%) $\mathrm{Pu}^{238}$, the contamination being due to the new $\mathrm{Pu}^{238}$ forming some $\mathrm{Pu}^{239}$ during the irradiation of the remaining $\mathrm{Np}^{237}$. In the above sequence, however, there is one assumption-namely, $\mathrm{Np}^{237}$ is irradiated only after it is chemically separated from the $\mathrm{U}^{238}$ in the slightly enriched uranium fuel; otherwise, the $\mathrm{U}^{238}$ will form so much $\mathrm{Pu}^{239}$ that the specific heat of the $\mathrm{Pu}^{238}-\mathrm{Pu}^{239}$ mixture will be tremendously reduced (about $99 \%$ ) from that of reasonably pure $\mathrm{Pu}^{238}$. The second way that $\mathrm{Pu}^{238}$ can be formed requires two steps (but only one neutron)-name1y, $\mathrm{Am}^{241}$ captures a neutron to form $\mathrm{Cm}^{242}$, and $\mathrm{Cm}^{242}$ alpha-decays into $\mathrm{Pu}^{238}$. To obtain $\mathrm{Am}^{241}$, one can allow $\mathrm{Pu}^{241}$ to decay either in or out of the reactor. Plutonium 241 that is separated and allowed to decay outside the reactor will form pure $\mathrm{Am}^{241}$, whereas $\mathrm{Pu}^{241}$ decay inside the reactor during irradiation will form a mixture of $\mathrm{Am}^{241}$ and $\mathrm{Am}^{243}$, and this mixture will contain 1 ess Am $^{241}$ because of the neutron captures by $\mathrm{Am}^{241}$. It should be noted that the rate at which $\mathrm{Pu}^{238}$ is formed 
from Am $^{241}$ will be 1 imited both by the availability of plutonium with a high content of $\mathrm{Pu}^{241}$ and by the $\mathrm{Pu}^{241}$ half-1ife of 13 years.

In contrast to $\mathrm{Pu}^{238}$, there is essentially only one way to form $\mathrm{Cm}^{244}$-namely, by neutron captures in $\mathrm{Am}^{243}$, which is formed by neutron captures in $\mathrm{Pu}^{242}$ and to a 1 ess extent, in $\mathrm{Am}^{242}$.

It should also be noted, in connection with Figure 2 , that the amounts of $\mathrm{Pu}^{238}$ and $\mathrm{Cm}^{244}$ produced depend on (1) the alpha $\left(\sigma_{\mathrm{c}} / \sigma_{\mathrm{f}}\right)$ of $\mathrm{U}^{235}, \mathrm{Pu}^{239}, \mathrm{Pu}^{241}$, and, to a less extent, $\mathrm{U}^{233}$, and (2), also to a less extent, the $n-2 n$ reaction of $\mathrm{U}^{238}$. Furthermore, the value of alpha, particularly in the case of $U^{235}$ and $\mathrm{Pu}^{239}$, is sensitive to the energy of the captured neutrons.

Because a higher alpha means less fissioning and more production of transuranium isotopes, there is a possible trade-off between the two, depending on the market prices for the heat from fission in the reactor and for the heat from decay out of the reactor. Formerly, when there seemed to be little possibility of a market price for transuranium isotopes, the value of plutonium as a heat producer via fission was calculated on the basis of the upper error limits of alpha so as to avoid overstating the worth of plutonium. Now, however, a more accurate alpha must be used so as to avoid overstating the production of transuranium isotopes. Recent chemical analyses of discharged power-reactor fuels has increased the trustworthiness of the alpha values used in this study. (See Appendix A)

Figure 3 shows the computed production rates of $\mathrm{Pu}^{238}$, $\mathrm{Cm}^{244}$, and their immediately preceding isotopes. The computations were based on a simulated pressurized water reactor patterned after that reported by WCAP.(7) The Pu 238 and $\mathrm{Np}^{237}$ curves represent the production rates from slightly enriched

*A1though this report presents data for PWR and BWR designs, it should be noted that these designs are continually changing. Consequently, the data in this report apply to a particular stage in the evolution of power reactors (the $1000 \mathrm{MW}$ reference designs of the year 1963). 
Figure 3. ISOTOPE PRODUCTION AS A FUNCTION OF FUEL EXPOSURE IN A SIMULATED PRESSURIZED WATER REACTOR

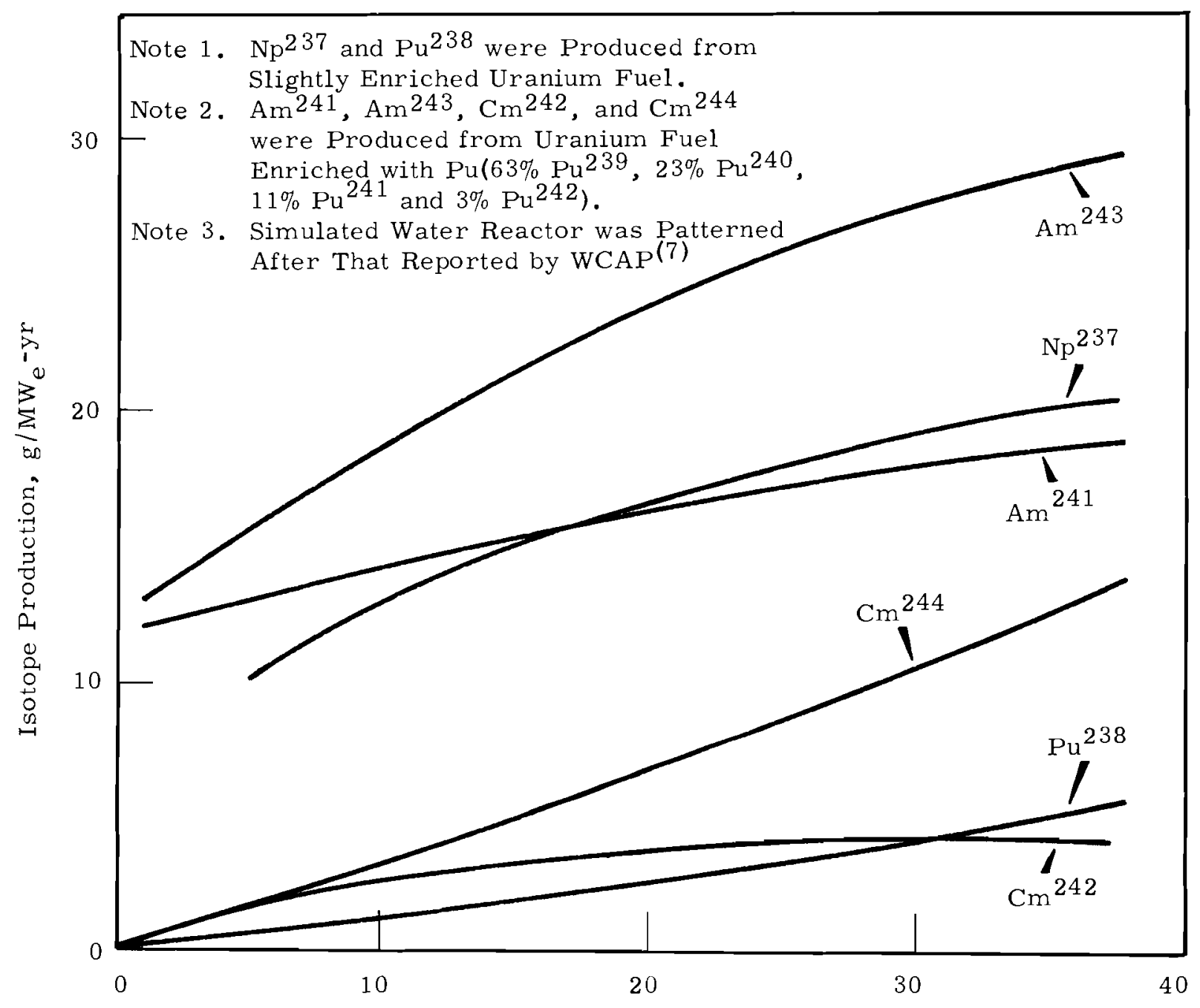

Fuel Exposure, MWd/kg 
uranium fuel, whereas those for americium and curium represent the production rates from fuel enriched with plutonium. Also, the $\mathrm{Pu}^{238}$ curve represents the production rate of $\mathrm{Pu}^{238}$ mixed with other plutonium isotopes, which, as already noted, greatly reduce the heat output of the mixture.

Curium 244 also has a purity problem. For when plutonium (a mixture of $\mathrm{Pu}^{239}, \mathrm{Pu}^{240}, \mathrm{Pu}^{241}$, and $\mathrm{Pu}^{242}$ ) is irradiated, $\mathrm{Cm}^{242}$ is always produced with the $\mathrm{Cm}^{244}$. And since $\mathrm{Cm}^{242}$ has an initial heat output 50 times greater than that of $\mathrm{Cm}^{244}$, the heat output of $\mathrm{Cm}^{244}$, which is relatively stable, will be temporarily masked if there is much $\mathrm{Cm}^{242}$ in the curium mixture. This purity problem, however, diminishes with time because the shorter half-life of $\mathrm{Cm}^{242}$ causes the percent of $\mathrm{Cm}^{244}$ in the. mixture to increase. And unless it is needed for an immediate application, $\mathrm{Cm}^{244}$ that is $98 \%$ pure is considered usable, even though the heat output of the mixture will drop about $35 \%$ in the first year. The rates at which $\mathrm{Cm}^{242}$ and $\mathrm{Cm}^{244}$ are produced depend on the cross section and half-life of their preceding isotopes $\left(\mathrm{Pu}^{242}, \mathrm{Am}^{241}\right.$, and $\left.\mathrm{Am}^{243}\right)$ during the production sequence. How much these cross sections change with a change in the epithermal flux/thermal flux ratio $\left(\phi_{1} / \phi_{2}\right)$ is indicated in Table III. (It should be noted that the cross sections in Table III include resonance data; if this study had used only the 2200 meter cross sections to calculate isotope production rates, the concentrations attained would have been grossly underestimated.) Table IV, on the other hand, shows the relative power successively generated by a curium mixture initially containing $86 \%$ wt. $\mathrm{Cm}^{244}$.

The Battelle report titled Formation of Transuranium Isotopes in Power Reactors (8) gives detailed calculations for the yields of transuranium isotopes from 24 different power 


\section{TABLE III}

SOME ISOTOPE PROPERTIES ${ }^{(a)}$

Effective Cross Sections (b)

Isotope

$\mathrm{Th}^{232}$

$0_{235}^{235}$

ठ०238

Npp 237

$\mathrm{Pu}^{238}$

$\mathrm{Pu}_{240}^{239}$

$\mathrm{Pu}^{240}$

$\mathrm{Pu}_{242}^{241}$

$\mathrm{Pu}^{242}$

$\operatorname{An}^{241}$

$\operatorname{An}_{242}^{242}$

$\mathrm{Am}^{243}$

Cif 242 $\phi_{1} / \phi_{2}=1^{(c)} \quad \phi_{1} / \phi_{2}=3 \quad \phi_{1} / \phi_{2}=6$

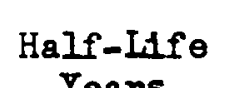

Alphe of Flssile Isotopes

Years
Potential Watts pera

Destroyed, $\phi_{1} / \phi_{2}=3$

$$
8.4
$$

9.6

11.5 Stable

602
23
5.0

180

453

1565

559

1602

88

$$
\begin{array}{r}
874 \\
7220 \\
146
\end{array}
$$

18

14
603

9.3

221

\section{5}

1759

1215

1601

276

1248

7201

340

18

14
597 Stablo

$\begin{array}{ll}11.8 & \text { Stable } \\ 14.4 & \text { Stable }\end{array}$

260 Stable

\section{7}

1914

1981

1573

497

1605

7140

553

18

13

$$
89
$$

Stable

Stable

13

Stable

458

152

7650

18.45
0.101

0.55

0.39

$\begin{array}{lll}0.50 & 0.53 & 0.55 \\ 0.37 & 0.38 & 0.39\end{array}$

\footnotetext{
(a) Includes resonance data.

(b) The effective cross sections include the effect of thermal flux depression which increases with an increasing flux ratio. The enrichment at each flux ratio was sufficient to attain a fuel exposure of $25 \mathrm{MWd} / \mathrm{kg}$.

(c) $\phi_{1} / \phi_{2}=$ epithermal flux/thermal flux $=$ flux ratio.
} 
TABIE IV

RELATIVE POWER (W/MWe-YEAR) SUCCESS IVELY GENERATED BY A CUR IUM MIXTURE INITIALUY CONTAINING $86 \%$ WEIGHT CUR IUM-244

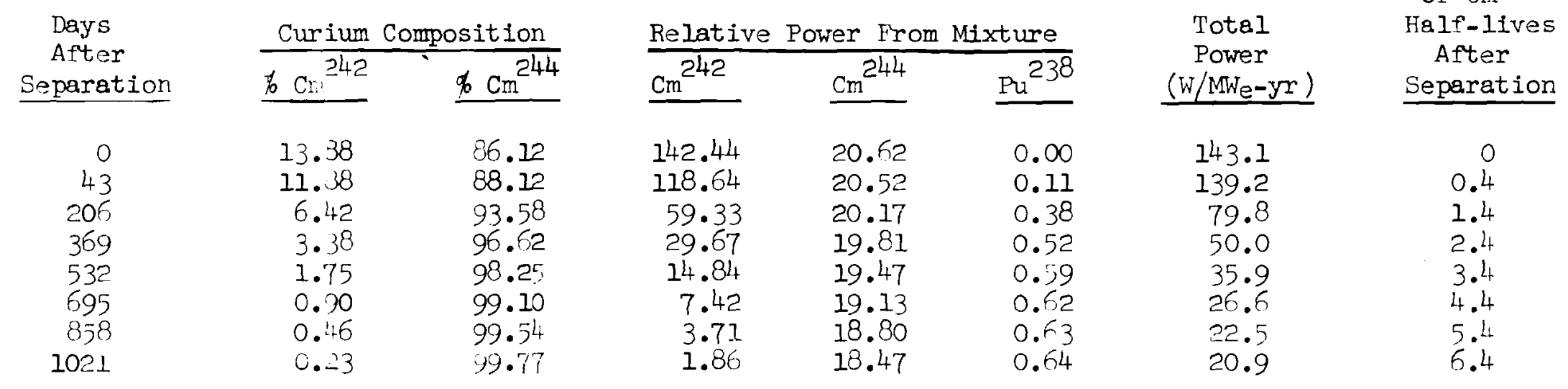


reactor fueling schemes. These include:

(1) Slightly enriched uranium, with plutonium recycled in simulated pressurized water reactors (PWR's) and simulated boiling water reactors (BWR's)

(2) Slightly enriched uranium, with plutonium, americium, and $\mathrm{U}^{236}$ recycled in a $\mathrm{PWR}$

(3) Plutonium in natural uranium for various neutron spectra

(4) Plutonium mixed with zirconium

(5) Fully enriched $U^{235}$, with $U^{236}$ recycled

(6) Plutonium and fully enriched $U^{235}$ in a variable neutron spectrum reactor

(7) $\mathrm{Am}^{241}$ and $\mathrm{Np}^{237}$ targets in a water reactor. PRODUCTION OF $\mathrm{Pu}^{238}$ VIA Np ${ }^{237}$

Neptunium 237 is formed directly from $U^{236}$, which, in turn, is formed directly from $U^{235}$. Because the alpha of $U^{235}$ and the cross section of $\mathrm{U}^{236}$ (see Table III) both become greater with an increase in epithermal flux, there are at least three ways to increase the production of $\mathrm{Np}^{237}$ per unit of heat generated: (1) increasing the energy of the neutron spectrum either by

* Resonance Doppler broadening affects almost al1 isotopes. In general, the higher the isotope temperature, the greater the effective resonance cross section, and the higher the alpha value of a fissile isotope. Since this paper is concerned with power reactor fuels, the effect of temperature increases beyond those normally occurring in power reactors is not considered. 
raising the neutron temperature or by tightening the lattice so as to increase the alpha of $\mathrm{U}^{235}$, (2) recycling $\mathrm{U}^{236}$, and (3) increasing the number of $\mathrm{U}^{235}$ fissions per megawatt of heat generated. Neptunium ${ }^{237}$ production via the $\mathrm{U}^{238} \mathrm{n}-2 \mathrm{n}$ reaction can also be increased by increasing the fast flux, which is proportional to the $U^{238}$ fast effect, or $\varepsilon$ in the classical four factor formula.

As the curves in Figure 4 show, the $\mathrm{Np}^{237}$ yield greatly increases as the energy of the neutron spectrum becomes more epithermal. The curve with a fixed initial $\phi_{1} / \phi_{2}$ ratio of 1.0 represents the spectrum of a well moderated reactor; the curve with a fixed initial $\phi_{1} / \phi_{2}$ ratio of 3.0 (slightly enriched uranium fuel) represents a soft spectrum power reactor; the curve with a fixed initial $\phi_{1} / \phi_{2}$ ratio equal to 6.0 represents the harder spectrum power reactor designs.

Figure 4 also shows the $\mathrm{Np}^{237}$ yield when $\mathrm{U}^{236}$ is recycled at concentrations of 0.5 and $1.0 \mathrm{~kg} / \mathrm{MT}$. This recycling, however, usually requires blending fully enriched $\mathrm{U}^{235}$ with depleted fuel-a costly technique which, to be worthwhile, must be offset by $\mathrm{Np}^{237}$ revenues.

Particular attention must be given to the PWR and BWR* curves in Figure 4. Unlike the other curves in the figure, these curves have a variable initial $\phi_{1} / \phi_{2}$ ratio and apply to specific reactor types. The reason the initial flux ratio varies is that the geometry (rod spacing) of these reactors is constant; and, as the initial fuel enrichment in such reactors increases in order to achieve a certain exposure, the resulting increase in thermal blackness increases the initial flux ratio when the exposure changes.

* This curve is based on data in the General Electric report GEAP-4476, entitled 1000 MWe Boiling Water Reactor Plant Feasibility Study ( 3 vols). 
Figure 4. Np237 PRODUCTION FOR VARIOUS FLUX RATIOS

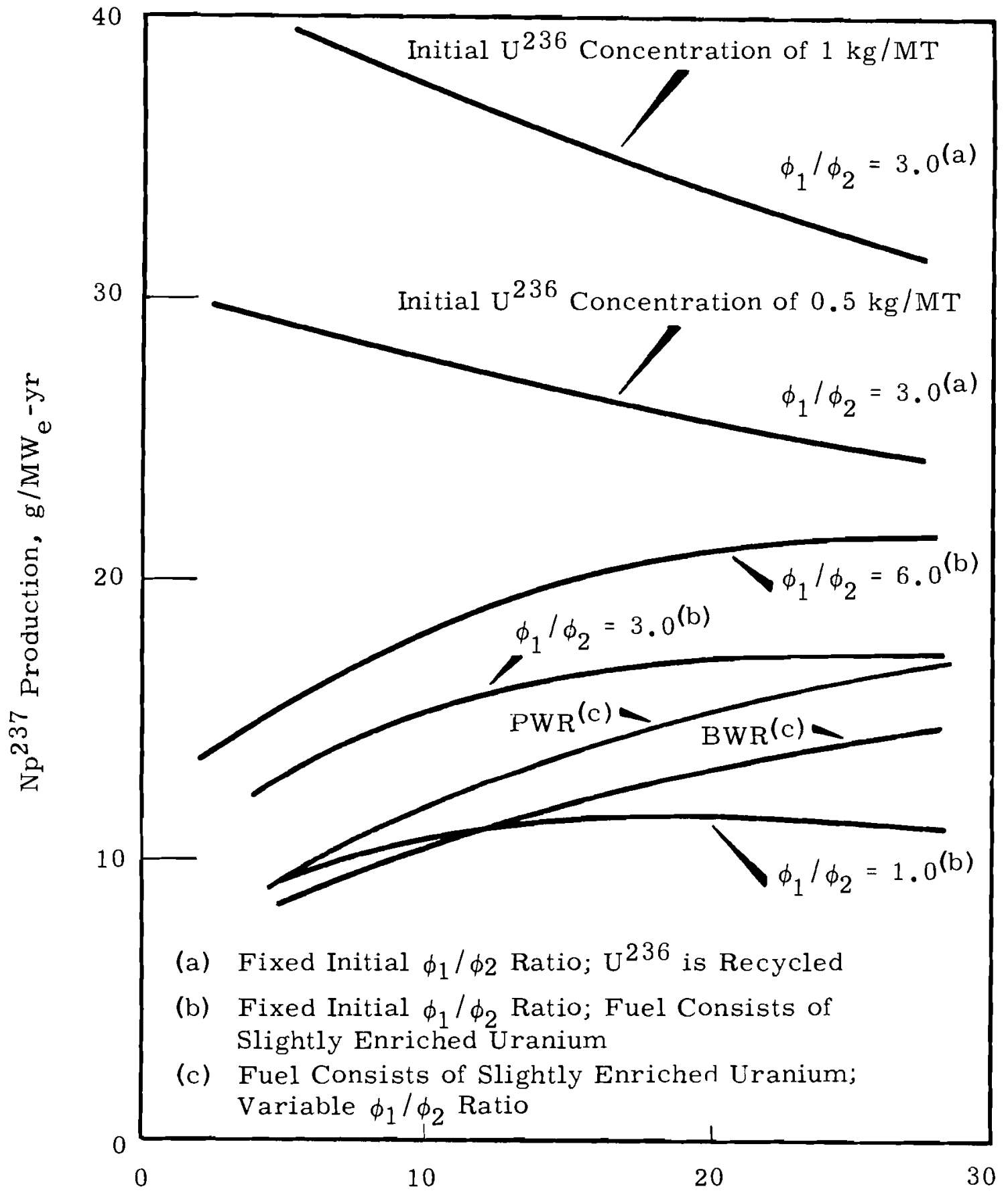

Fuel Exposure, MWd/kg 
The other curves in Figure 4 have fixed initial $\phi_{1} / \phi_{2}$ ratios because their purpose is to show how reactor types in general can increase the production rate of $\mathrm{Np}^{237}$. Consequently, care must be taken when applying those curves to an individual reactor: a correction must be made to include the increase in the initial $\phi_{1} / \phi_{2}$ ratio; for when the initial fuel enrichment is increased in order to achieve a higher exposure, there is a corresponding increase in thermal blackness, which in turn increases the initial epithermal flux/thermal flux ratio. It should be noted in Figure 4, however, that the flux ratio of each curve varies (from the initial value) when the fuel blackness changes during the burnup.

Because $\mathrm{U}^{238}$ always accompanies $\mathrm{U}^{235}$, some $\mathrm{Pu}^{239}$ will be produced when $\mathrm{U}^{235}$ is irradiated to form $\mathrm{U}^{236}$; and this $\mathrm{Pu}^{239}$ will account for a sizable portion of the fuel fissions. In fact, during the lifetime of a water reactor operating on slightly enriched uranium, $50 \%$ of the fissions will occur in plutonium. However, by using more highly enriched uranium, which reduces the amount of $\mathrm{U}^{238}$ and plutonium competing with $\mathrm{U}^{235}$ and $\mathrm{U}^{236}$ for neutrons, the production of $\mathrm{Np}^{237}$ can be further increased. (See Figure 5.)

Whether fully (93\%)* enriched uranium is an economically attractive fuel for directly producing $\mathrm{Pu}^{238}$ depends on the price of $\mathrm{Pu}^{238}$ and $\mathrm{Np}^{237}$, as will be explained later. If 65\% pure $\mathrm{Pu}^{238}$ is acceptable, producing $\mathrm{Pu}^{238}$ directly from fully enriched uranium would avoid the necessity of encapsulating and irradiating $\mathrm{Np}^{237}$ as a special target.

$$
\text { PRODUCTION OF } \mathrm{Pu}^{238} \text { VIA } \mathrm{Cm}^{242}
$$

If plutonium, preferably with a high $\mathrm{Pu}^{241}$ content, is separated and allowed to beta-decay outside the reactor, the * The remaining $7 \%$ is mostly $\mathrm{U}^{238}$, from which is formed $\mathrm{Pu}^{239}$
at a significant rate. 


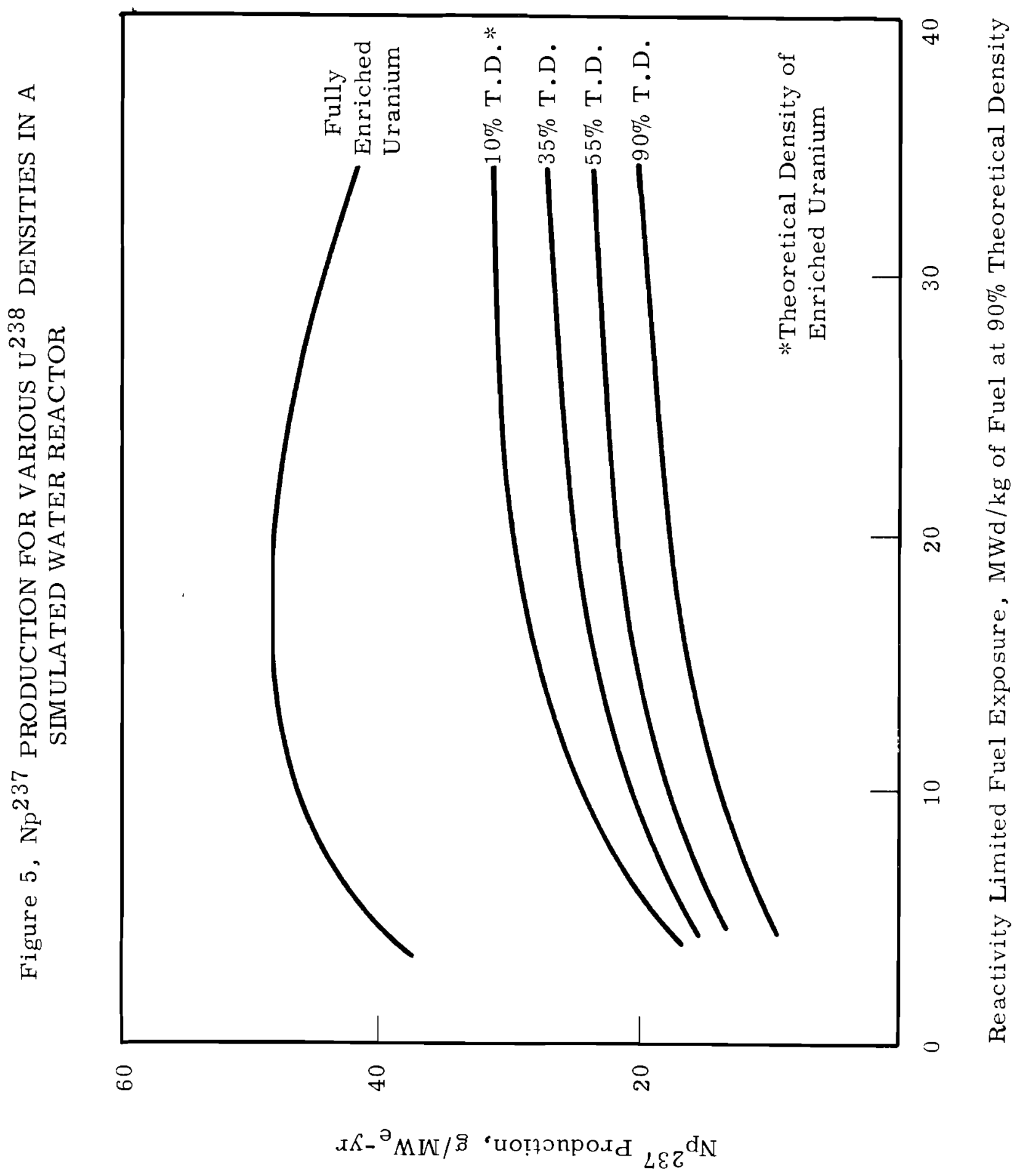


resulting $\mathrm{Am}^{241}$ can be chemically separated and irradiated as a target to form $\mathrm{Cm}^{242}$, which will then decay into pure $\mathrm{Pu}^{238}$. This two-decay process is inherently slow, but it may be economically attractive if the price of $\mathrm{Pu}^{238}$ is high enough to offset the interest charge on the out-of-reactor plutonium or if the storage of plutonium for sale to fast reactor operators is considered worthwhile. (Americium ${ }^{241}$ and $\mathrm{Cm}^{242}$ also have value: $\mathrm{Am}^{241}$ in applications where low specific power is required for a long period, and $\mathrm{Cm}^{242}$ where high specific power is required for a short period; renting the use of $\mathrm{Cm}^{242}$ as a heat source would be one way of defraying at least the inventory costs that $\mathrm{Cm}^{242}$ incurs while it decays into $\mathrm{Pu}^{238}$.)

Plutonium 238 will be contaminated if produced by a process that allows $\mathrm{Pu}^{241}$ to decay inside the reactor. For if the process produces $\mathrm{Pu}^{238}$ from a chemically separated mixture either of curium $\left(\mathrm{Cm}^{242}\right.$ and $\mathrm{Cm}^{244}$ ) or of americium $\left(\mathrm{Am}^{241}\right.$ and $\mathrm{AM}^{243}$ ), the alpha decay of $\mathrm{Cm}^{244}$ will cause the product to be about $40 \%$ contaminated with $\mathrm{Pu}^{240}$.

In his detailed analysis of the problems associated with $\mathrm{Pu}^{238}$ formation $\mathrm{via} \mathrm{Am}^{241}$ and $\mathrm{Cm}^{242}$, Lang(9) points out that the optimum $\mathrm{Am}^{241}$ irradiation time is shorter than the time between water-reactor discharge schedules, and that the production of $\mathrm{Pu}^{238}$ from $\mathrm{Am}^{241}$ targets would be better accomplished by using either reactors that have on-line charging or production reactors that have frequent discharge schedules. Lang also mentions that, because of losses incurred by $\mathrm{Am}^{242}$ fissions, the use of very high fluxes, which may be available in special production reactors, is not necessarily the best technique for irradiating $\mathrm{Am}^{241}$ targets.

It should be mentioned here that, unlike Lang's study ${ }^{(9)}$, the present study did not attempt to maximize $\mathrm{Cm}^{242}$ production, because the short half-life of $\mathrm{Cm}^{242}$ is incompatible with normal power-reactor discharge schedules. 
Production of $\mathrm{Cm}^{244}$ can be increased by hardening the spectrum - that is, by raising the $\phi_{1} / \phi_{2}$ ratio. In Figure 6 , the production rate of $\mathrm{Cm}^{244}$ is indicated for three $\phi_{1} / \phi_{2}$ ratios at neutron temperatures of $120{ }^{\circ} \mathrm{C}, 360^{\circ} \mathrm{C}$, and $600{ }^{\circ} \mathrm{C}$ when the fue 1 consists of natural uranium enriched with plutonium $\left(63 \% \mathrm{Pu}^{239}\right.$, $23 \% \mathrm{Pu}^{240}, \quad 11 \% \mathrm{Pu}^{241}$, and $\left.3 \% \mathrm{Pu}^{242}\right)$. The increased production rate is due to two effects. One effect is the cross section increase of $\mathrm{Pu}^{242}$ as the spectrum hardens. For example, Table III (page 14) shows that the effective neutron absorption cross section of $\mathrm{Pu}^{242}$ is 88 barns for a $\phi_{1} / \phi_{2}$ ratio of 1 , and 497 barns for a $\phi_{1} / \phi_{2}$ ratio of 6 . Notice also in Table III that there is a corresponding cross section increase in $\mathrm{Am}^{243}$ and $\mathrm{Pu}^{240}$, whereas the other cross sections in the $\mathrm{Cm}^{244}$ production sequence remain almost constant. The other effect accounting for an increased $\mathrm{Cm}^{244}$ production rate is the increase in the alpha of $\mathrm{Pu}^{239}$ throughout this same range $(1.0,3.0$, and 6.0$)$ of $\phi_{1} / \phi_{2}$ ratios. Because of this second effect, which is due to spectrum hardening and neutron temperature increases, more $\mathrm{Pu}^{239}$ atoms will escape fission, ultimately forming more $\mathrm{Cm}^{244}$ per gram of plutonium destroyed. Thus not only the production rate but also the amount of $\mathrm{Cm}^{244}$ produced per $\mathrm{Pu}^{239}$ atom destroyed will be increased.

Observe also in Figure 6 that the higher $\mathrm{Cm}^{244}$ production rates are due much more to higher $\phi_{1} / \phi_{2}$ ratios than to higher neutron temperatures. But note, too, that temperature changes at low $\phi_{1} / \phi_{2}$ ratios cause a greater percent of increase in the production rate than temperature changes at high $\phi_{1} / \phi_{2}$ ratios.

The production rate of $\mathrm{Cm}^{244}$ can also be increased by the obvious step of augmenting the initial concentration of $\mathrm{Pu}^{242}$. Figure 7 indicates that the initial plutonium concentration having the highest percent of $\mathrm{Pu}^{242}$ also has the greatest production rate. 


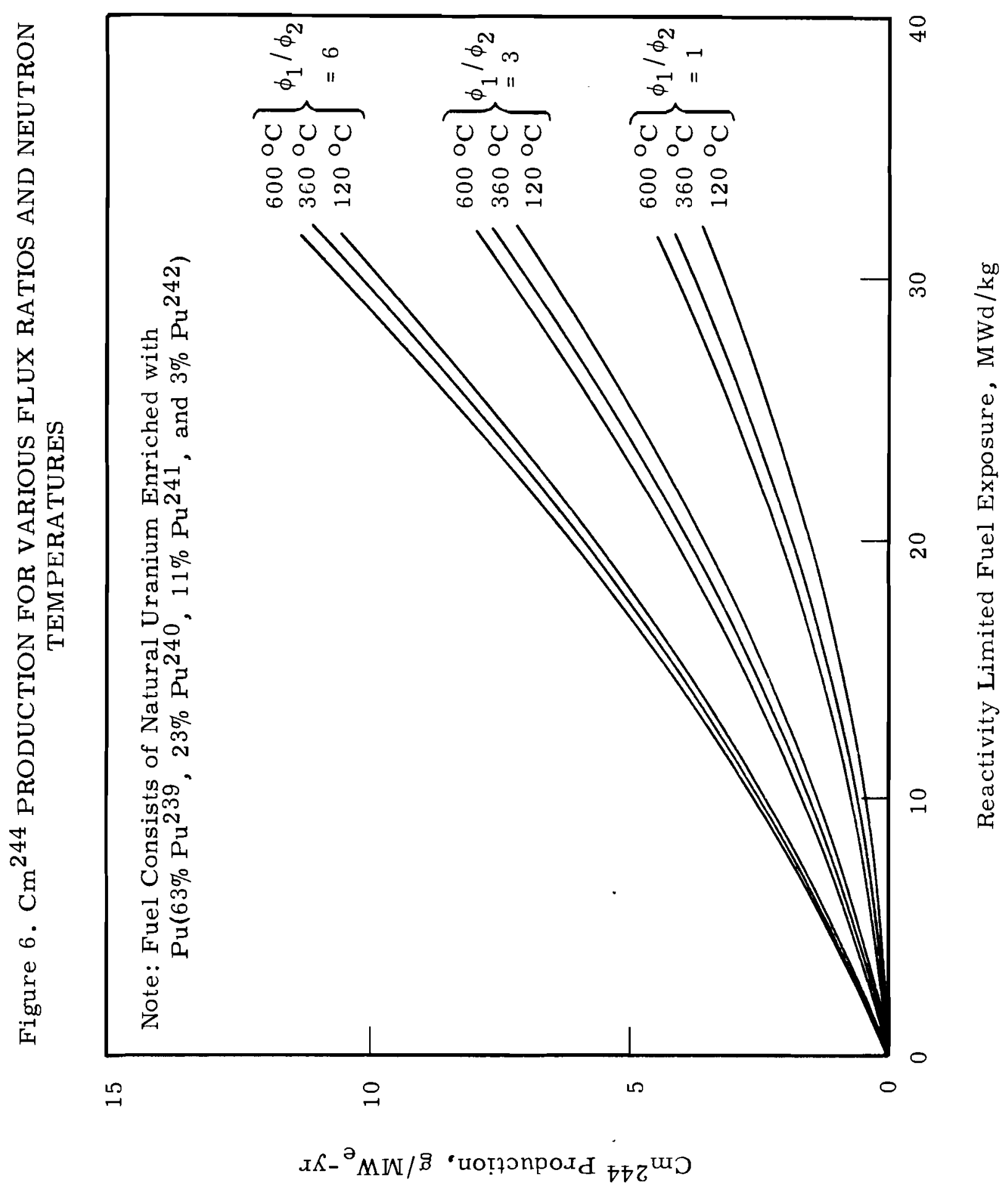




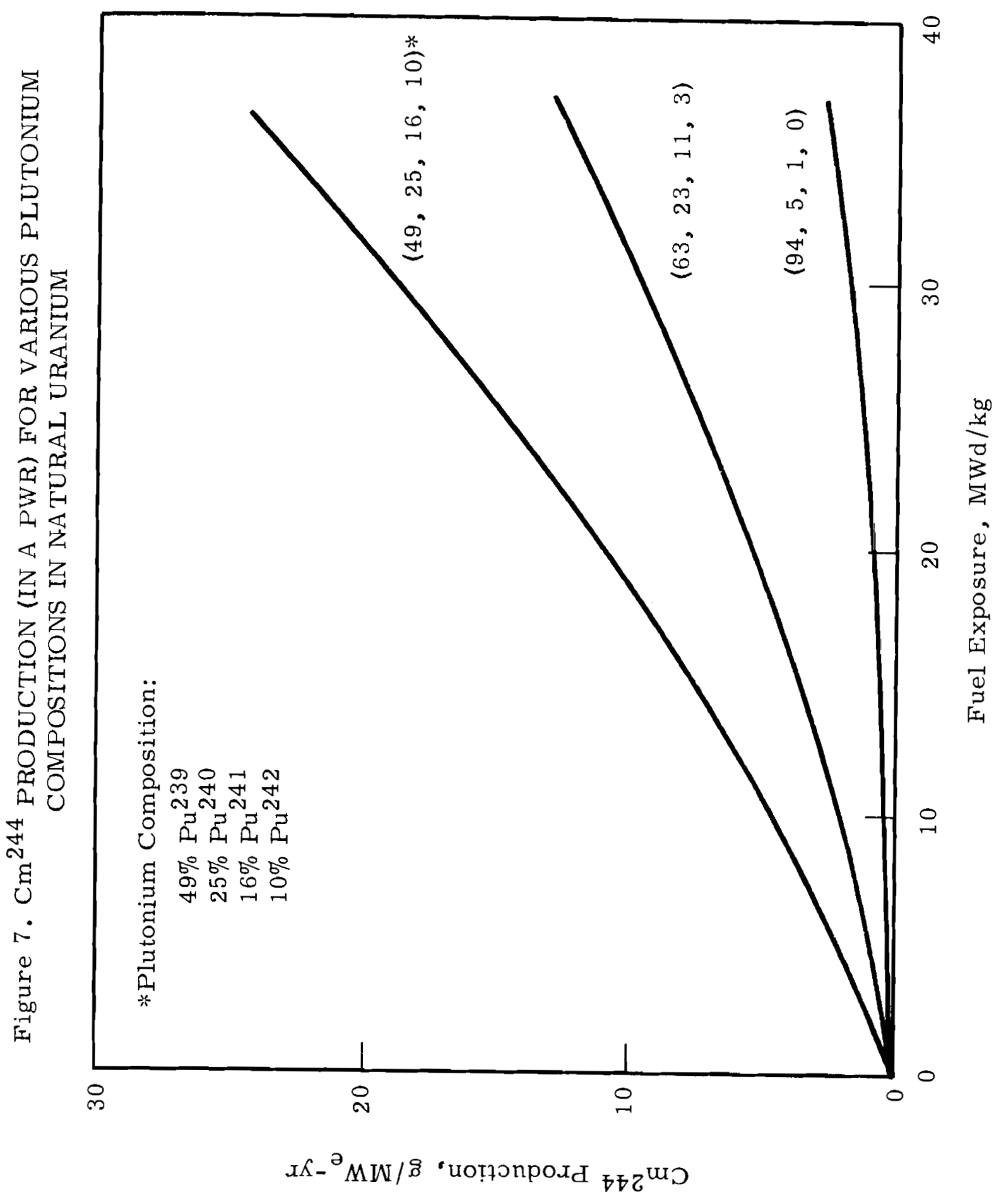


Each of the three curves in Figure 7 is based on a different plutonium enrichment of a natural uranium diluent in a power reactor. The plutonium enrichment with $0 \% \mathrm{Pu}^{242}$ represents the fuel discharge from a fast reactor blanket region; the enrichment with $3 \% \mathrm{Pu}^{242}$ represents the fuel discharge from a uranium enriched cycle in which the reactivity limited exposure is about $20 \mathrm{MWd} / \mathrm{kg}$; and the enrichment with $10 \% \mathrm{Pu}^{242}$ represents the fuel discharge after two or three recycles in slightly enriched uranium. If the two curves representing $\mathrm{Cm}^{244}$ production from initial $\mathrm{Pu}^{242}$ concentrations of $3 \%$ and $10 \%$ had included the americium from their previous cycle, their slopes would have been much steeper.

FUELING SCHEMES FOR INCREASING THE PRODUCTION RATE

$$
\text { AND PURITY OF CURIUM } 244
$$

Calculations were made to determine whether the $\mathrm{Cm}^{244}$ production rate and purity could be improved by using $\operatorname{Th}^{232}$ instead of $\mathrm{U}^{238}$ as a fertile fuel. Results show that using $\mathrm{U}^{238}$ has a distinct advantage, especial1y in wel1 moderated reactors, because the absorption cross section of $\mathrm{U}^{238}$ is about one-half that of $\mathrm{Th}^{232}$. $\mathrm{U}^{238}$, therefore, requires less enrichment than $\mathrm{Th}^{232}$, and hence the greater flux with $\mathrm{U}^{238}$ at the same power level causes a higher $\mathrm{Cm}^{244}$ production rate and purity. However, this advantage diminishes if the thorium density is reduced so as to make its soft spectrum cross section equal to that of $\mathrm{U}^{238}$. The advantage of $\mathrm{U}^{238}$ over $\mathrm{Th}^{232}$ also diminishes when the $\mathrm{U}^{238}$ cross section increases with a harder spectrum. But since $\mathrm{U}^{238}$ augments the initial plutonium enrichment, whereas $\mathrm{Th}^{232}$ does not, $\mathrm{U}^{238}$ will still maintain its production advantage in a harder spectrum.

Calculations were also made to determine the effect of different fueling schemes on $\mathrm{Cm}^{244}$ production in a simulated water 
moderated power reactor. The results are shown in Figure 8 . Cases 2 and 3 in the figure are based on the assumptions that plutonium is recycled and that the price of transuranium isotopes is such that there is no incentive to increase production. But if one assumes that the price of curium and americium is sufficiently high to encourage greater $\mathrm{Cm}^{244}$ production, Cases 4 , 5 , and 6 in Figure 8 would be attractive alternatives to consider, because a fuel mixture of plutonium and zirconium would not have any neutron losses to uranium in the plutonium natural-uranium fue1. Notice also in these cases that the production of $\mathrm{Cm}^{244}$ increases with an increase in the percent of initial $\mathrm{Pu}^{242}$. Lastly, Cases 7 and 8 in Figure 8 represent fueling schemes in which a small amount of plutonium (with zirconium) is mixed with $\mathrm{U}^{235}$ driver fuel. These cases-the one with $3 \% \mathrm{Pu}^{242}$, the other with $10 \% \mathrm{Pu}^{242}$ are designed to produce very pure $\mathrm{Cm}^{244}$ very rapidly. (Plutonium has a higher cross section than $\mathrm{U}^{235}$ and wi11, therefore, burn out more quickly at a high effective flux density.)

All eight fueling schemes in Figure $8^{*}$ have the same specific power because the exposures for Cases 4 through 8 , which have no natural uranium, are based on grams per ton equivalent to those of natural uranium. For this reason, one can compare the eight fue 1ing schemes and draw the following conclusions: (1) slightly enriched uranium produces $\mathrm{Cm}^{244}$ at the slowest rate; (2) plutonium mixed with natural uranium increases the rate of production: the more $\mathrm{Pu}^{242}$ in the composition, the greater the $\mathrm{Cm}^{244}$ production rate, (3) plutonium mixed with zirconium, instead of with natural uranium, increases the $\mathrm{Cm}^{244}$ production rate still more: the more $\mathrm{Pu}^{242}$ in the composition, the greater the $\mathrm{Cm}^{244}$ production rate;

* The incidental production of $\mathrm{Cm}^{242}$ from the eight fueling schemes represented in Figure 8 can be calculated by simply multiplying the $\mathrm{Cm}^{244} \mathrm{~g} / \mathrm{MW}_{\mathrm{e}} \mathrm{yr}$ values in Figure 8 for a given exposure by 1 minus the corresponding purities in Figure 9 . 
Figure 8. $\mathrm{Cm}^{244}$ PRODUCTION FROM VARIOUS FUELING SCHEMES IN A SIMULATED WATER REACTOR

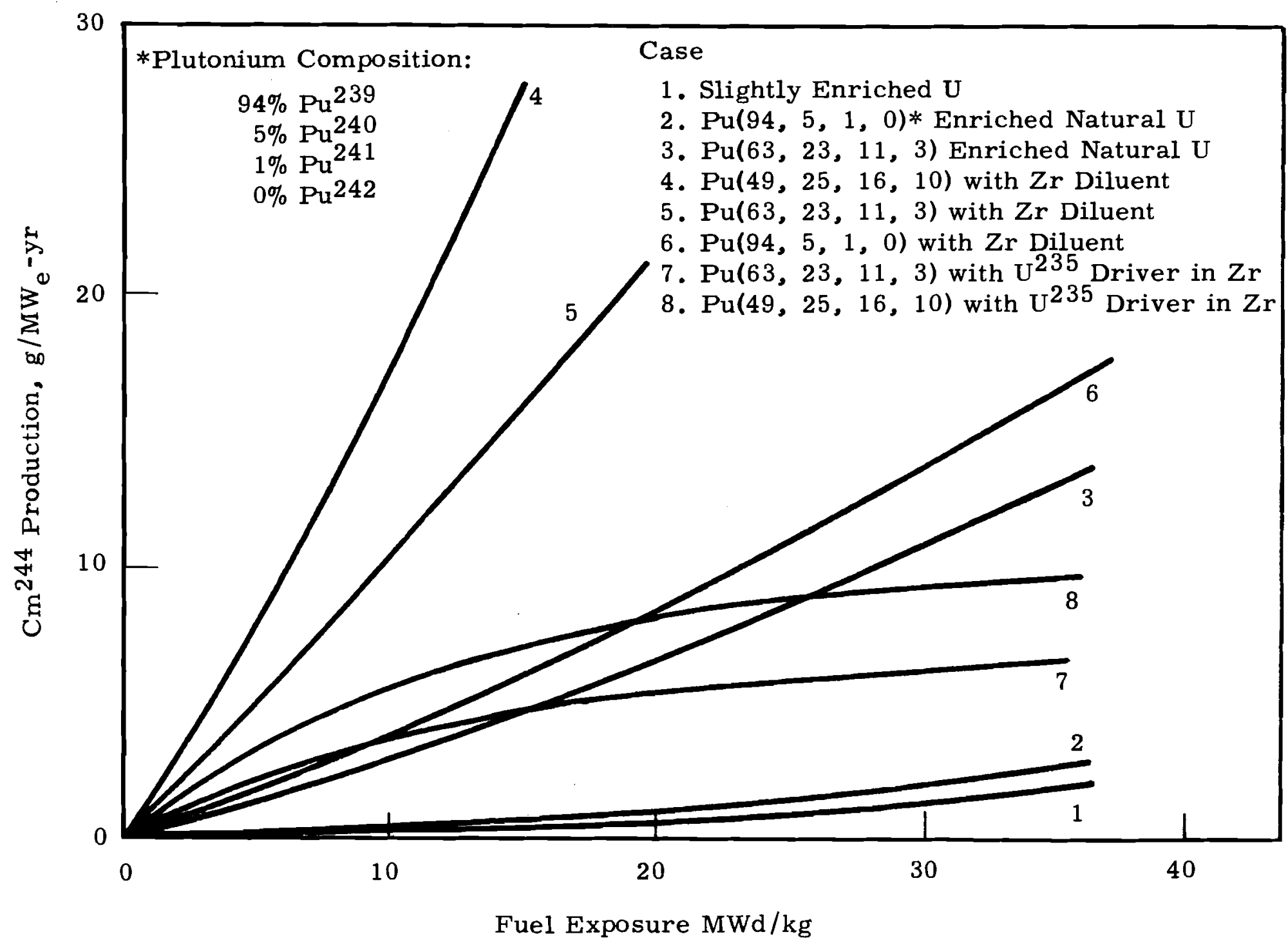


(4) a small amount of plutonium (with zirconium) in $\mathrm{U}^{235}$ driver fuel rapidly produces more and purer $\mathrm{Cm}^{244}$ : the more $\mathrm{Pu}^{242}$ in the composition, the more and the purer $\mathrm{Cm}^{244}$ obtained.

It is also important to know the $\mathrm{Cm}^{244}$ purities produced by different fueling schemes, because the $\mathrm{Cm}^{244}$ obtained by irradiating plutonium or americium is always contaminated with $\mathrm{Cm}^{242}$, and the full amount of usable $\mathrm{Cm}^{244}$ is not available until almost al1 the $\mathrm{Cm}^{242}$ has decayed into $\mathrm{Pu}^{238}$. (Curium-242, however, has value both because the initial heat output of its decay is very high and recoverable (for some applications) and because it is a precursor to $\mathrm{Pu}^{238}$.) Figure 9 illustrates the different $\mathrm{Cm}^{244}$ purities obtained from the eight fueling schemes whose production rates are shown in Figure 8. Not surprisingly, the siightly enriched uranium fuel produces 10 -purity $\mathrm{Cm}^{244}$; and when plutonium with no $\mathrm{Pu}^{242}$ (Case 2) is used as an enrichment, the flux leve1 is reduced because of the large plutonium fission cross section, the result being that the $\mathrm{Cm}^{244}$ purity is almost the same as that from slightly enriched uranium fuel. However, when plutonium with more $\mathrm{Pu}^{242}$ is used as an enrichment (Case 3), the effect of the fluxlevel decrease is overridden, so that the $\mathrm{Cm}^{244}$ purity is greater than that from slightly enriched uranium fuel; moreover, by removing the fertile material $\mathrm{U}^{238}$, the purity of $\mathrm{Cm}^{244}$ increases stil1 further (Cases 4, 5, and 6); and the purity is greatest in Cases 7 and 8 where only a small amount of plutonium is mixed with $\mathrm{U}^{235}$. The high purities shown for Cases 7 and 8 , even for low exposures of less than $10 \mathrm{MWd} / \mathrm{kg}$, suggest that if $\mathrm{Cm}^{244}$ were needed for immediate use, the fastest way to obtain large and pure amounts of it would be to irradiate a fuel in which a small amount of plutonium was mixed with $\mathrm{U}^{235}$. This fueling scheme would also produce significant quantities of $\mathrm{U}^{236}$ and $\mathrm{Np}^{237}$.

$$
\frac{\text { RECYCLING PRECURSOR ISOTOPES TO PRODUCE Pu }{ }^{238}}{\text { AND Cm } \mathrm{Cm}^{244} \text { IN POWER REACTORS }}
$$

As shown in Tables V, VI, and VII, the production of transuranium heat sources can be increased by recycling the precursor isotopes. Table $\mathrm{V}$ shows that recycling plutonium and americium increases the production of $\mathrm{Cm}^{244} 51.5$ times (from 8 to $433 \mathrm{~g} / \mathrm{MT}$ ). (Unlike recycling americium, recycling plutonium is economically 
Figure $9 . \mathrm{Cm}^{244}$ PURITIES OBTAINED FROM VARIOUS FUELING SCHEMES IN A SIMULATED WATER REACTOR

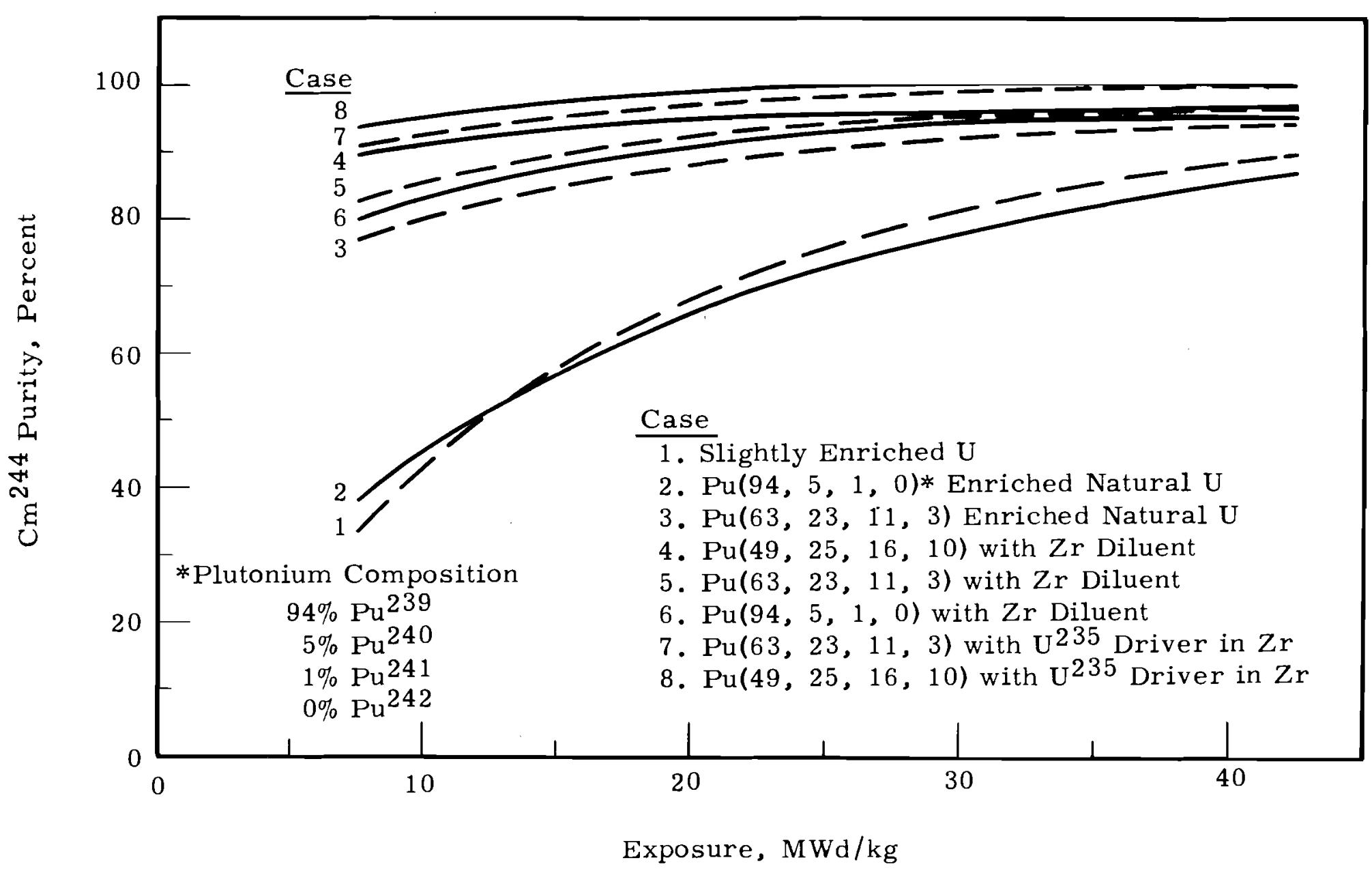


RECYCLE OF PLUTONIUM AND AMERICIUM TO FORM CURIUM ${ }^{242}$, CURIUM ${ }^{244}$, AND PLUTONIUM ${ }^{238}$ IN A PWR

US ING SITGHTIY ENR ICHED URANIUM AS SUPPIDAMENTAL ENR ICHMENT

(Fuel Exposure of $24 \mathrm{MWd} / \mathrm{kg}$ per Cycle)

Isotopic Concentration $\mathrm{g} / \mathrm{Mr}$ (One Year After Discharge)

\begin{tabular}{|c|c|c|c|c|c|c|c|c|c|c|c|c|c|}
\hline $\begin{array}{l}\text { Cycle } \\
\text { No. }\end{array}$ & $\begin{array}{l}\text { Initial } \\
\text { Fuel }\end{array}$ & $\begin{array}{c}\text { Enrich- } \\
\text { ment, } \\
\text { wt of }\end{array}$ & $\mathrm{Pu}^{239}$ & $\mathrm{Pu}^{240}$ & $\mathrm{Pu}^{24 \mathrm{I}}$ & $\mathrm{Pu}^{242}$ & $\mathrm{Am}^{241}$ & $\mathrm{Am}^{243^{(a)}}$ & $\mathrm{Cm}^{242}$ & $\mathrm{Cm}^{244}$ & $\mathrm{Pu}^{238^{(\mathrm{b})}}$ & $\begin{array}{l}\mathrm{Pu}^{238^{(\mathrm{c})}} \\
\text { Purity, }\end{array}$ & \\
\hline 1 & 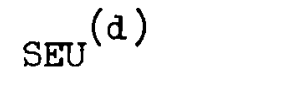 & 2.92 & 5518 & 1882 & 995 & 255 & 88 & 45 & 2.6 & 8.4 & 3.7 & 95 & \\
\hline 2 & $\begin{array}{l}\text { SEU with plu- } \\
\text { tonium and } \\
\text { americium re- } \\
\text { cycled from } \\
\text { cycle No. } 1\end{array}$ & 3.27 & 6579 & 2831 & 1773 & 778 & 256 & 258 & 9.6 & 102.6 & 13.5 & 85 & $\omega$ \\
\hline & $\begin{array}{l}\text { SEU with plu- } \\
\text { tonium and } \\
\text { americium re- } \\
\text { cycled from } \\
\text { cycle No. } 2\end{array}$ & 3.57 & 7136 & 3223 & 2249 & 1217 & 301 & 537 & 14.5 & 270.1 & 20.3 & 77 & \\
\hline & $\begin{array}{l}\text { SEU with plu- } \\
\text { tonium and } \\
\text { americium re- } \\
\text { cycled from } \\
\text { cycle No. } 3\end{array}$ & 3.82 & 7514 & 3413 & 2498 & 1533 & 359 & 797 & 17.5 & 433.9 & 24.4 & 71 & $\sum_{i}^{\infty}$ \\
\hline 1 & $\begin{array}{l}\text { ludes pure Am } \\
\text { tonium }{ }^{238} \text { form } \\
\text { h other }{ }^{2} \text { lutor } \\
\text { tonium } 238 \text { purd } \\
\text { ght } 1 y \text { enriched }\end{array}$ & $\begin{array}{l}\text { formed } \\
\text { only fy } \\
\text { isoto } \\
=\mathrm{Pu}^{23} \\
\text { anium. }\end{array}$ & $\begin{array}{l}\text { eer } \mathrm{s} \\
\mathrm{Cm}^{24} \\
\text { and } \\
100 /\end{array}$ & $\begin{array}{l}\text { atic } \\
\text { cay } \\
\frac{i}{3} 8^{i v}\end{array}$ & $\begin{array}{l}\text { er fu } \\
239+\end{array}$ & $\begin{array}{l}\text { epro } \\
40\end{array}$ & $\begin{array}{l}\text { sing } \\
241\end{array}$ & $\begin{array}{l}\text { days a } \\
+2 \text { ). }\end{array}$ & a & ge), & dis not & ycled & N \\
\hline
\end{tabular}




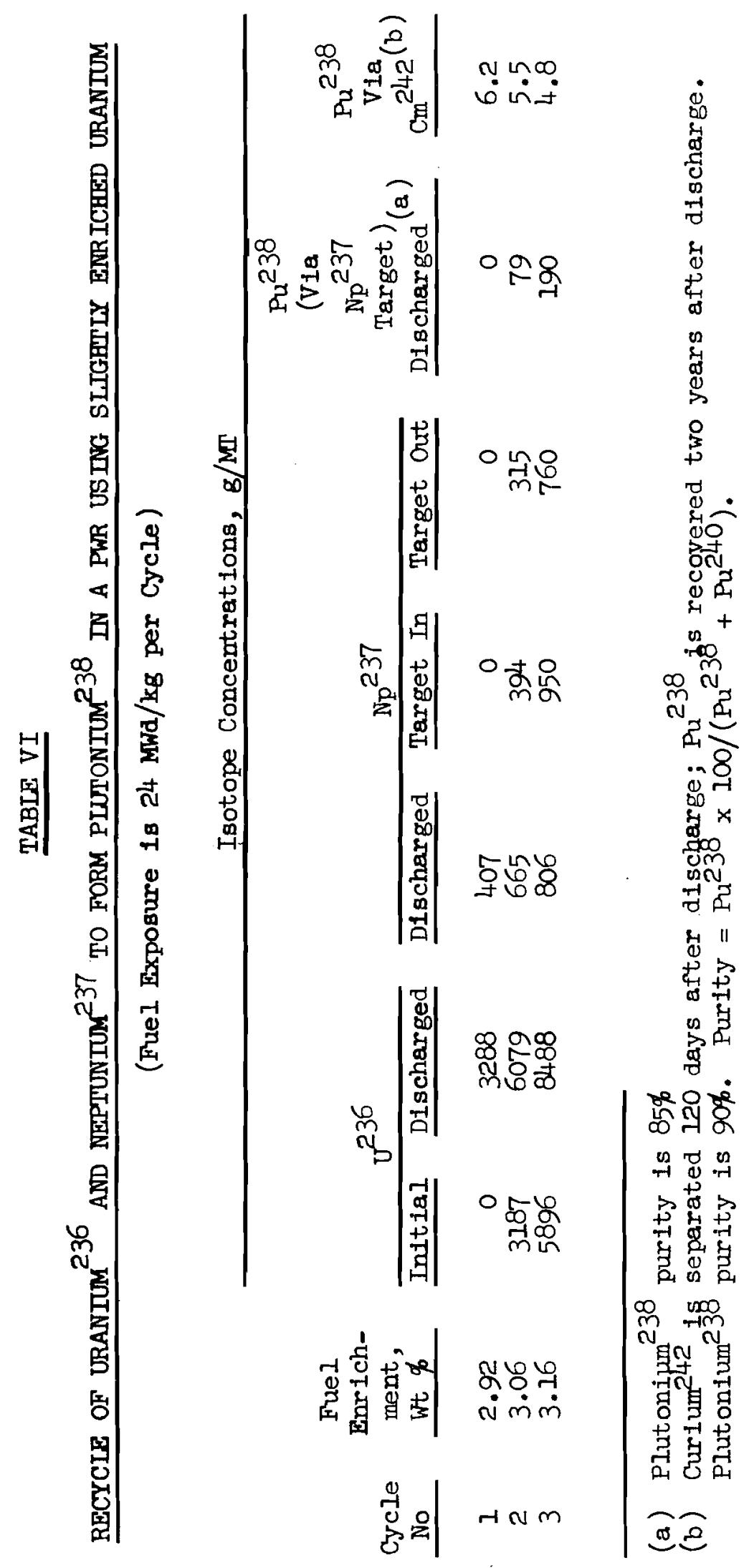




\section{TABLE VII}

RECYCIE OF URANIUM ${ }^{236}$ AND NEPTUNIUM ${ }^{237}$ TO FORM PLUTONIUM ${ }^{238}$ IN A PWR USIIG FULTY ENRICHED URANIUM

(Fuel Exposure is $24 \mathrm{MWd} / \mathrm{kg}$ per Cycle)

Isotope Concentrations, $\mathrm{g} / \mathrm{MP}$

\begin{tabular}{|c|c|c|c|c|c|c|c|c|}
\hline \multirow[b]{2}{*}{$\begin{array}{l}\text { Cycle } \\
\text { No. }\end{array}$} & \multirow{2}{*}{$\begin{array}{l}\text { Fuel } \\
\text { Enrich- } \\
\text { ment, } \\
\text { wt o }\end{array}$} & \multicolumn{2}{|c|}{$u^{236}$} & \multicolumn{3}{|c|}{$\mathrm{Np}^{237}$} & \multicolumn{2}{|c|}{$\mathrm{Pu}^{238} \mathrm{Via}$} \\
\hline & & Initial & Discharged & Discharged & Target In & Target out & Direct $^{(\mathbf{a})}$ & Target $^{(b)}$ \\
\hline $\begin{array}{l}1 \\
2 \\
3\end{array}$ & $\begin{array}{l}3.16 \\
3.21 \\
3.26\end{array}$ & $\begin{array}{r}0 \\
3747 \\
6500\end{array}$ & $\begin{array}{l}3863 \\
6701 \\
8970\end{array}$ & $\begin{array}{l}1150 \\
1643 \\
1953\end{array}$ & $\begin{array}{r}0 \\
1115 \\
2485\end{array}$ & $\begin{array}{r}0 \\
892 \\
1988\end{array}$ & $\begin{array}{l}559 \\
777 \\
902\end{array}$ & $\begin{array}{r}0 \\
223 \\
497\end{array}$ \\
\hline
\end{tabular}

(a) PIutonium 238 purity is $65 \%$.

(b) PIutonium 238 purity is $85 \%$. 
attractive in its own right, even if it is not used to produce $\mathrm{Cm}^{244}$, because plutonium can serve as a thermal reactor fuel, whereas americium is a reactor poison.) Table VI shows how much the production of $\mathrm{Pu}^{238}$ is increased if the $\mathrm{U}^{236}$ in discharged fuel is recycled and if the $\mathrm{Np}^{237}$ formed during the previous cycle is encapsulated and irradiated as a target. Note that recycling $\mathrm{U}^{236}$ increases the amount of $\mathrm{Np}^{237}$ by $50 \%$ (from 525 to $829 \mathrm{~g} / \mathrm{MT}$, and from 824 to $1044 \mathrm{~g} / \mathrm{MT}$ ) and that the amount of $\mathrm{Pu}^{238}$ produced from encapsulated $\mathrm{Np}^{237}$ is simply a function of the flux time during irradiation. Table VI shows that approximately $21 \%$ of the original $\mathrm{Np}^{237}$ encapsulated as a target is converted into $\mathrm{Pu}{ }^{238}$ during a $24 \mathrm{MWd} / \mathrm{kg}$ burnup in a rod adjacent to the target capsule. Another way to produce $\mathrm{Pu}^{238}$ is to irradiate fully enriched uranium fuel, although the product $\mathrm{Pu}^{238}$ will be less pure than that from an $\mathrm{Np}^{237}$ target-65\% and $85 \%$ respective $1 \mathrm{y}$. However, Table VII shows that the production of $65 \%$ pure $\mathrm{Pu}^{238}$ is from 3 to 6 times greater than the production of $85 \%$ pure $\mathrm{Pu}^{238}$ per megawatt day of heat removed from the fuel.

\section{INDIFFERENCE PRICES FOR TARGET ISOTOPES}

In discussing Figure 7 (page 24), it was observed that when the initial plutonium composition contains a higher percentage of $\mathrm{Pu}^{242}$, the $\mathrm{Cm}^{244}$ production rate will be greater. And, as was pointed out, the production rates in Figure 7 would have been even greater if americium from the previous cycle had been included. Consequently, if a price is assigned to $\mathrm{Cm}^{244}$, a value will also exist for the americium and plutonium isotopes, particularly $\mathrm{Pu}^{242}$; and this value will reflect both the value they already have as thermal reactor fuels and that due to them as $\mathrm{Cm}^{244}$ producers. However, that part of the value due to them as $\mathrm{Cm}^{244}$ producers will depend both on their nearness to $\mathrm{Cm}^{244}$ in the production sequence and on the difficulty with which they are moved through the sequence. 
The equitable price relationship between a product isotope price and the value of a target isotope is adequately expressed (as a first approximation) by the target indifference price. This price is the amount that a reactor operator pays for a target whose product yields a return sufficient to make the fuelcycle cost* of slightly enriched uranium fuel with the target equal to the fuel-cycle cost* of the same fuel without the target. When a target has such a price, a reactor operator is "indifferent" costwise to the two types of fuel since both fuels have the same fuel-cycle cost; or at such a target price, a reactor operator breaks even with either type of fuel.

Figure 10 shows the target indifference price of $\mathrm{Np}^{237}$ for a given $\mathrm{Pu}^{238}$ market price. If the narket price of $\mathrm{Np}^{237}$ is 1 ess than the $\mathrm{Np}^{237}$ indifference price, a reactor operator could lower his fuel-cycle cost by purchasing the target, irradiating it, and selling the product $\mathrm{pu}^{238}$. The target indifference price, therefore is the equilibrium point (equitable price) toward which the market price of a target would soon gravitate, eliminating windfall situations. But if the product $\left(\mathrm{Pu}^{238}\right.$ ) market price changes, so will the equilibrium point, the intersection of the two curves.

A calculation was performed to determine what effect various $\mathrm{Cm}^{244}$ market prices would have on the indifference prices of $\mathrm{Cm}^{244}$ precursor isotopes produced in a water reactor. In the 20 cases used in the calculation, the number of targets or target concentrations, or both, were varied. (See Table VIII.) The 20 cases were selected on the basis of the statistical requirements necessary to obtain a meaningful set of indifference prices from a minimum number of cases. This explains why some cases in

The sale of targets or product material formed from slightly enriched uranium must also be included when calculating the fuel-cycle cost. 


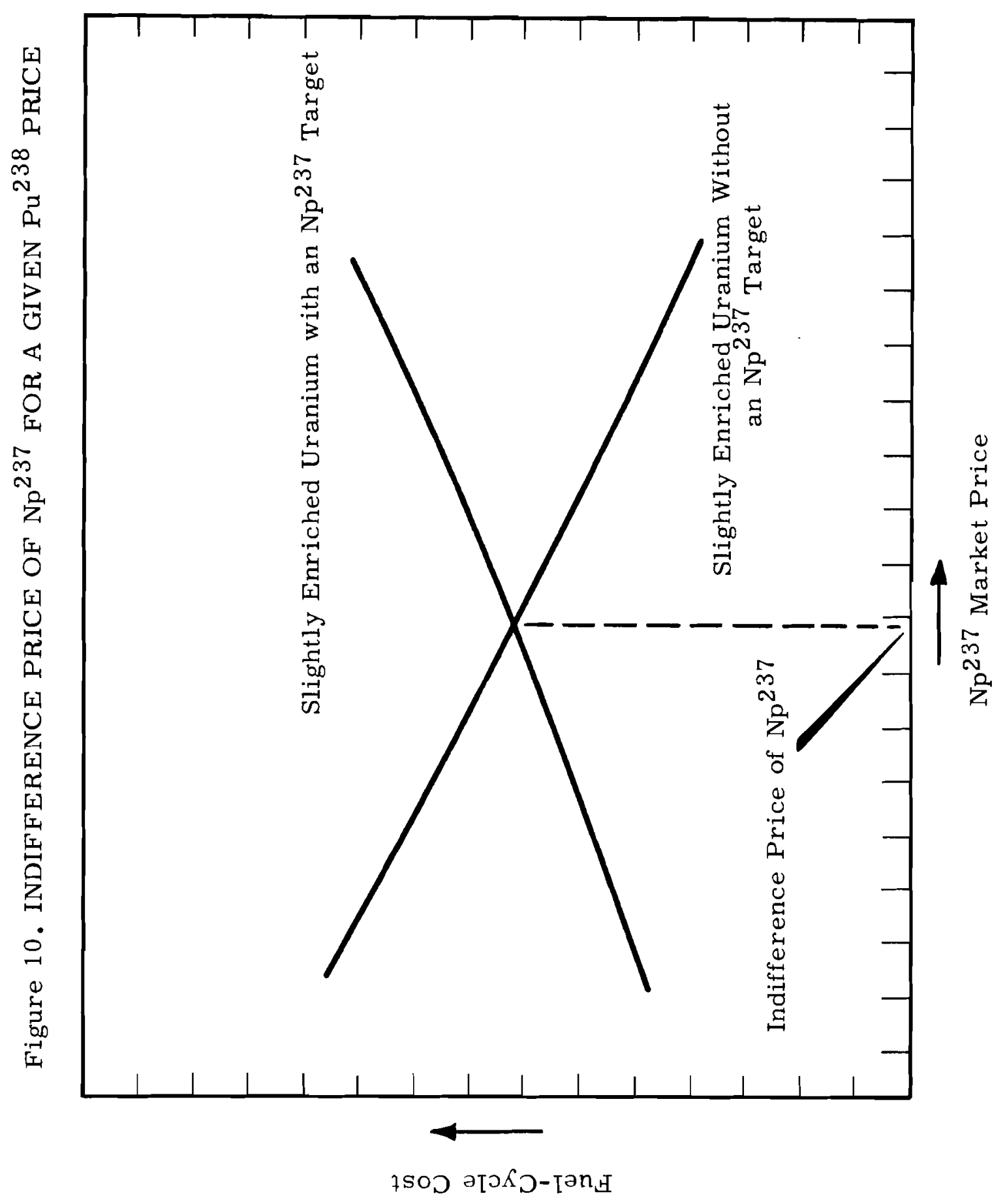




\section{TABLE VIII*}

TARGETS AND TARGET CONCENIRATIONS USED FOR DETERMINIING THE INDLFFFERENCE PRICES OF ISOTOPES IEADING TO CURTUM 244

Case

No.

$\mathrm{Pu}^{239}$

Isotope Target Concentrations, $\mathrm{g} / \mathrm{cc}$

\begin{tabular}{|c|c|c|c|c|c|}
\hline$\frac{1}{2}$ & $\begin{array}{l}0.1 \\
0.5\end{array}$ & & & & \\
\hline 3 & & $\begin{array}{l}0.1 \\
0.5\end{array}$ & & & \\
\hline $\begin{array}{l}5 \\
6\end{array}$ & & & $\begin{array}{l}0.1 \\
0.5\end{array}$ & & \\
\hline $\begin{array}{l}7 \\
8\end{array}$ & & & & $\begin{array}{l}0.1 \\
0.5\end{array}$ & \\
\hline 9 & & & & & 0.1 \\
\hline 10 & & & & & 0.5 \\
\hline 11 & 0.05 & 0.05 & & & \\
\hline 12 & 0.025 & 0.025 & & & \\
\hline 13 & 0.05 & 0.05 & 0.05 & & \\
\hline 14 & 0.025 & 0.025 & 0.025 & & \\
\hline 15 & 0.05 & 0.05 & 0.05 & 0.05 & \\
\hline 16 & 0.025 & 0.025 & 0.025 & 0.025 & \\
\hline 17 & 0.05 & 0.05 & 0.05 & 0.05 & 0.05 \\
\hline 18 & 0.025 & 0.025 & 0.025 & 0.025 & 0.025 \\
\hline 19 & 0.064 & 0.022 & 0.011 & 0.003 & \\
\hline 20 & 0.128 & 0.044 & 0.022 & 0.006 & \\
\hline
\end{tabular}

*This table is based on the statistical requirements for obtaining a meaningful set of indifference prices from a minimum number of cases. This explains why some cases have concentrations of pure isotopes and some cases have isotope combinations that do not normally occur during irradiation. 
Table VIII have concentrations of pure isotopes and somecases have combinations of isotopes that do not normally occur during irradiation. Furthermore, for any given $\mathrm{Cm}^{244}$ price in the calculation, the price of each target at each of its locations in the production sequence was adjusted by an iterative procedure until the fuel-cycle costs of a11 20 cases were equal to within $0.01 \mathrm{mill} / \mathrm{kWh}$ ef the fuel-cycle cost of slightly enriched uranium without a target. The results of the calculations are shown in Figure 11* Notice in the figure that the indifference price of $\mathrm{Pu} 239$ remains almost constant-namely, $\$ 10 / \mathrm{g}$, which is equal to its fuel value in a thermal reactor. However, $\mathrm{Pu}^{242}$, which is closer than $\mathrm{Pu}^{239}$ to $\mathrm{Cm}^{244}$ in the production sequence, acquires a credit sufficiently high to increase the value of plutonium fuel, in which it is normally a parasite that reduces the plutonium fuel value, as shown in the equation: Plutonium value $=A-B\left(\% \mathrm{Pu}^{242}\right.$ in plutonium $)$.

Another calculation, based on the same method, was performed to determine the effect that different $\mathrm{Pu}^{238}$ credits would have on the indifference prices of $\mathrm{Np}^{237}$ and $\mathrm{U}^{236}$. But this time, because of the shorter production sequence, on 1 y 8 cases were involved. The results of the calculation (see Figure 12) show that $\mathrm{Np}^{237}$ is worth from one-third to one-half the product price, and that $\mathrm{U}^{236}$, normally a parasite, is worth from $\$ 4 / \mathrm{g}$ to $\$ 10 / \mathrm{g}$, depending on the price assigned to $\mathrm{Pu}^{238}$.

Figure 13 shows the various indifference prices of $\mathrm{Am}^{241}$, another isotope leading to $\mathrm{Pu}^{238}$. This curve is based on the assumptions that $\mathrm{Am}^{241}$ is irradiated as a target to form $\mathrm{Cm}^{242}$ and that a11 the $\mathrm{Cm}^{242}$ existing in the capsule at discharge decays

All fuel-cycle costs in this study were calculated by the QUICK cost code. (10) 
Figure 11. TARGET INDIFFERENCE PRICES AS A FUNCTION OF $\mathrm{Cm}^{244}$ CREDIT (ISOTOPES ARE PRODUCED IN A SIMULATED WATER REACTOR)

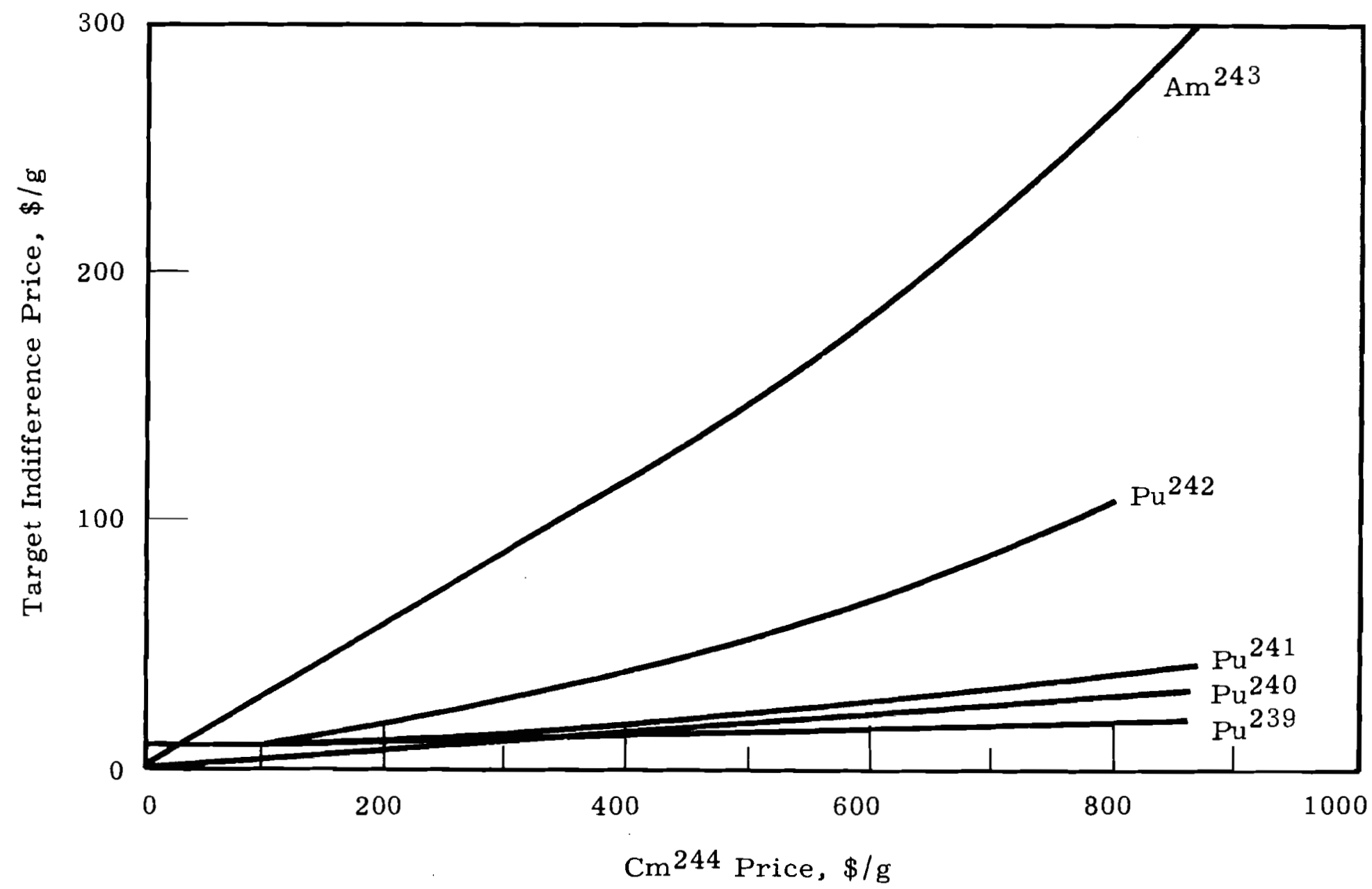




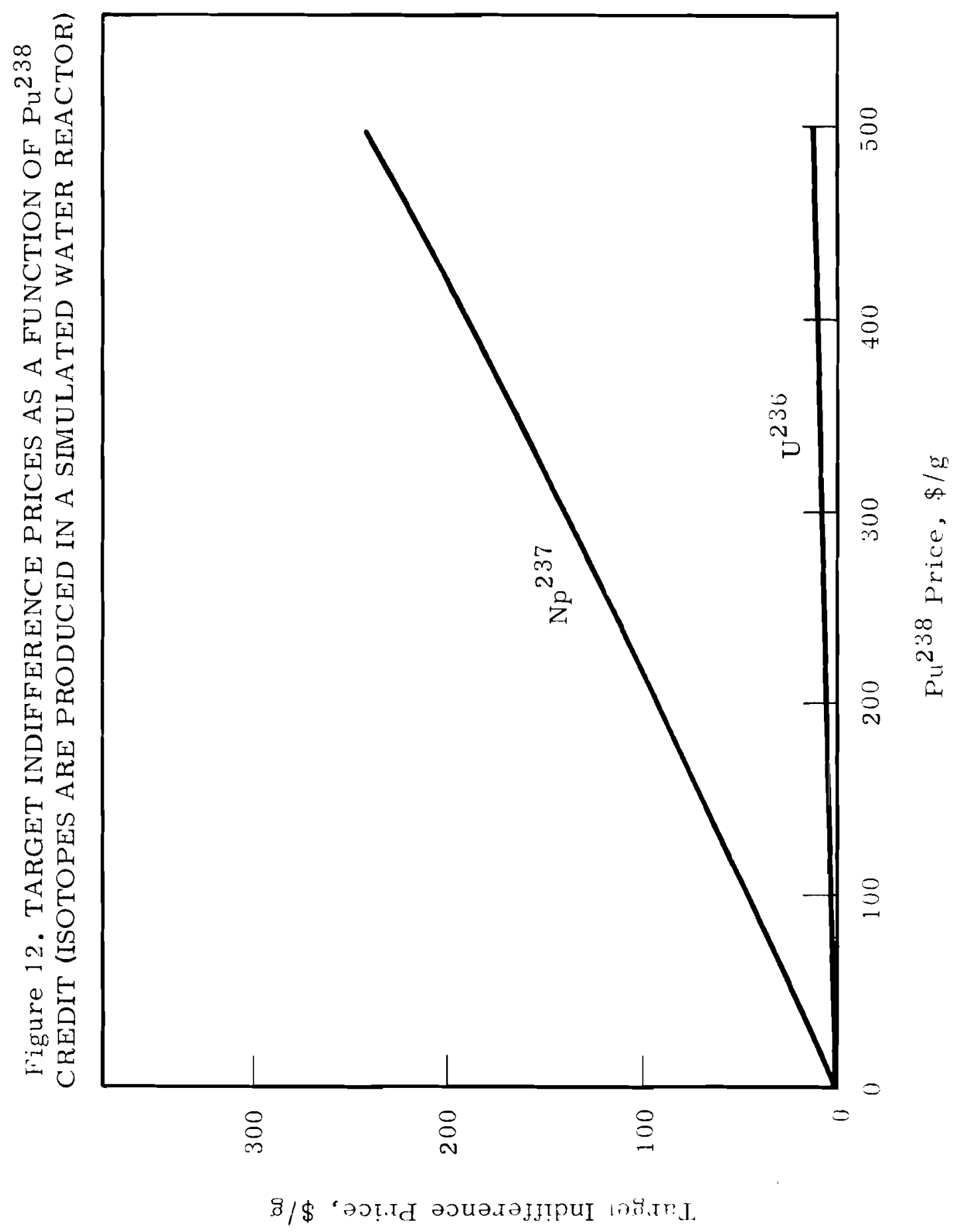




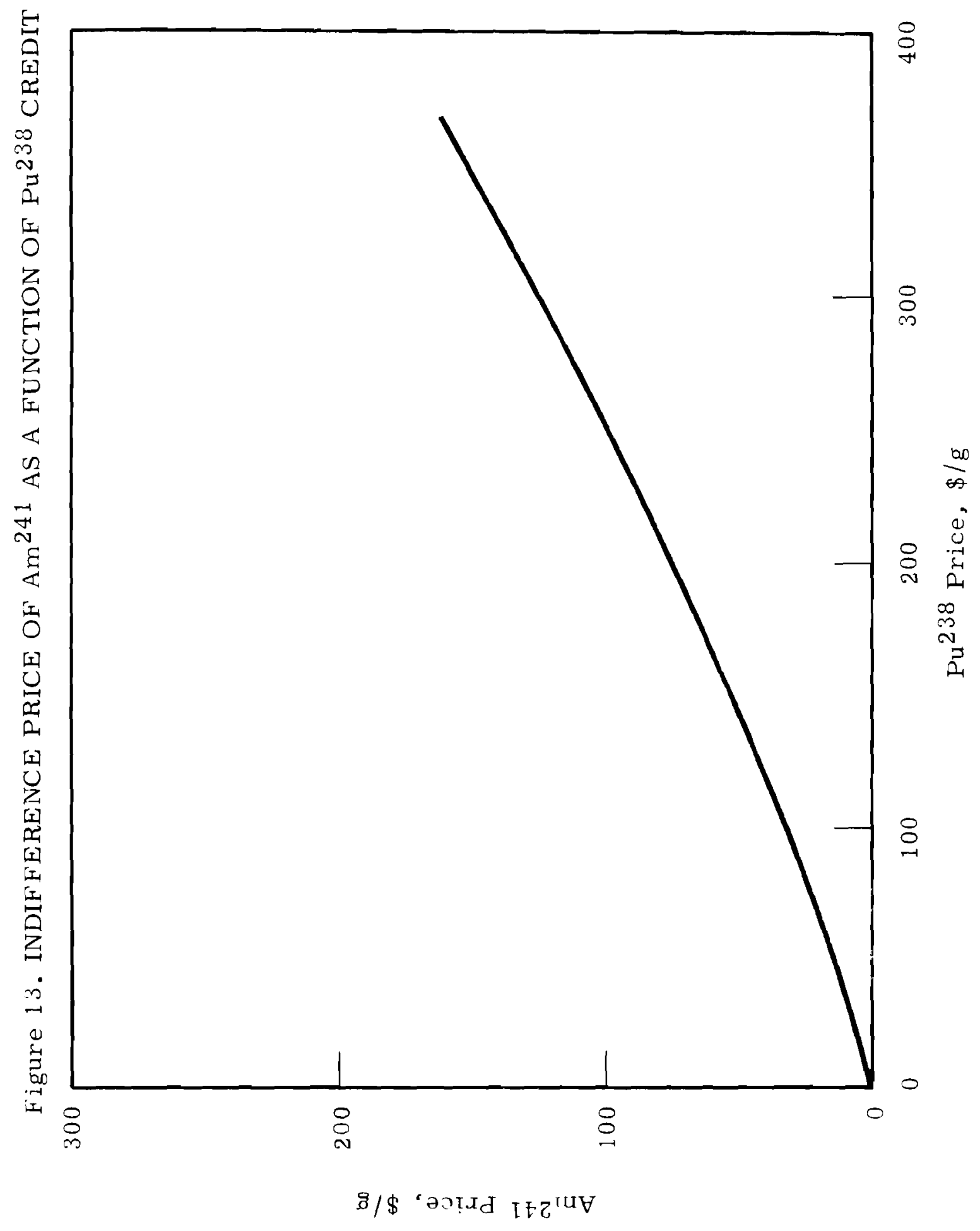


into $\mathrm{Pu} 238$. For the sake of simplicity, the indifference prices represented by the curve in Figure 13 do not include any credits for $\mathrm{Am}^{243}$ and $\mathrm{Cm}^{244}$ formed during the irradiation of $\mathrm{Am}^{241}$. Had these credits been included, more calculations involving interactions would have been necessary in order to relate the indifference price of $\mathrm{Am}^{241}$ to the market prices of $\mathrm{Am}^{243}$ and $\mathrm{Cm}^{244}$ as we 11 .

Since this report is mainly concerned with $\mathrm{Pu}^{238}$ and $\mathrm{Cm}^{244}$, the indifference prices presented thus far have not included various market prices for $\mathrm{Cm}^{242}$ as a power source. Including various market prices for this isotope would have increased the indifference prices of those isotopes that are also in the $\mathrm{Cm}^{242}$ production sequence.

\section{THE TOTAL COST OF PRODUCING TRANSURANIUM ISOTOPES} FROM TARGET MATERIALS

Whether power reactors or special reactors should be used to produce transuranium isotopes is a question beyond the scope of this report. It may be that maximum production would require a combination of the two types. In any event, before a power reactor operator can afford to buy and irradiate a target, the target market price must be equal to the target indifference price. And since the total cost of producing transuranium isotopes from target materials includes the processing costs (fabrication, separations, etc.), the effect of these costs on the target indifference price will now be considered. According to Figure 14, a reactor operator can afford to buy $\mathrm{Np}^{237}$ at $\$ 100 / \mathrm{g}$ only if the $\mathrm{Pu}^{238}$ credit is at least $\$ 215.00$ and the $\mathrm{Np}^{237}$ processing costs are $\$ 0.00 . *$ But if the processing costs are $\$ 10 / \mathrm{g}$, then $\mathrm{Np}^{237}$

* The $\mathrm{Np}^{237}$ curve for $\$ 0.00$ processing costs in Figure 14 is the same as the $\mathrm{Np} 237$ curve in Figure 12 . 
Figure 14. THE EFFECT OF PROCESSING COSTS ON THE INDIFFERENCE PRICE OF Np $\mathrm{Np}^{237}$ PRODUCED IN A SIMULATED WATER REACTOR

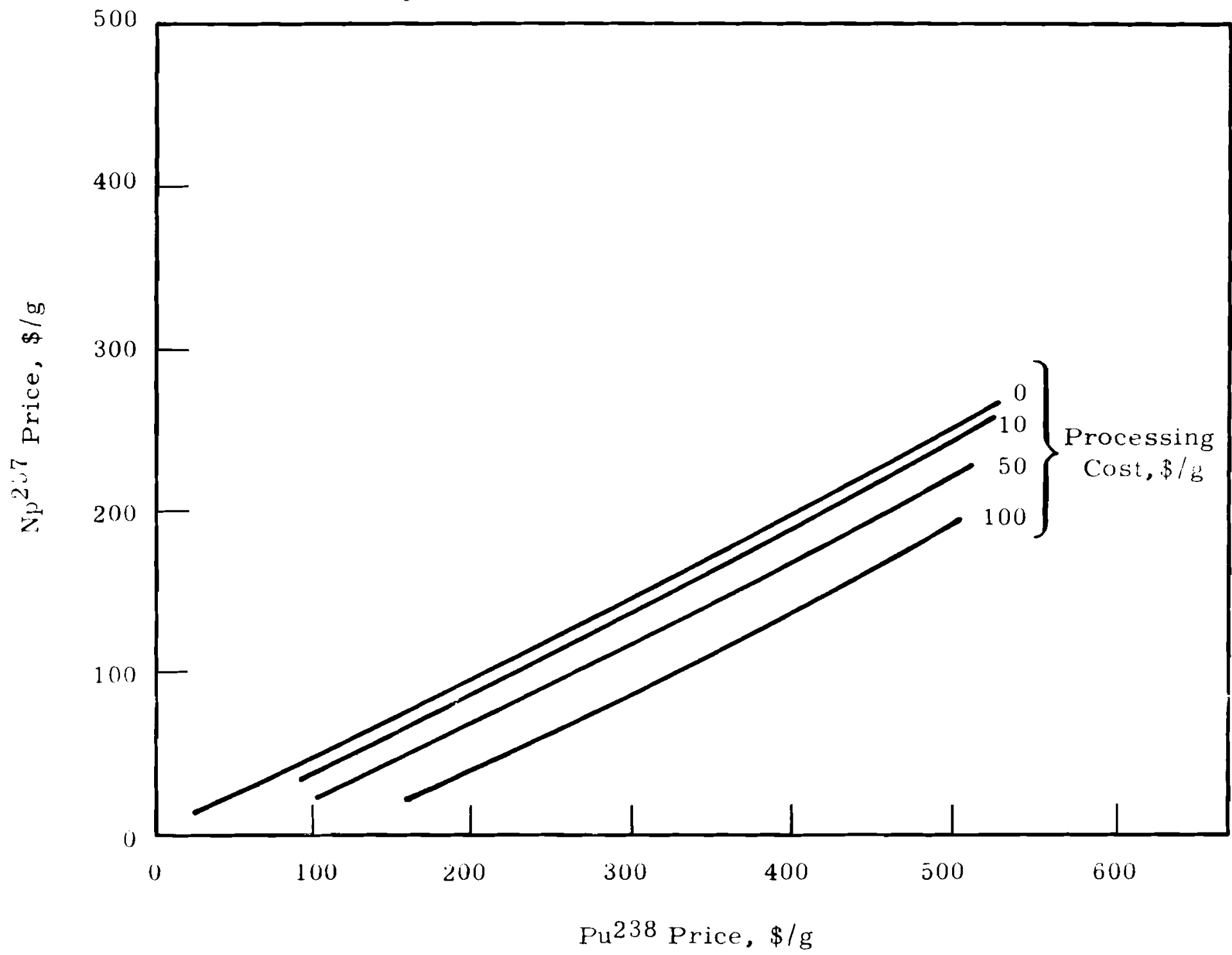


at $\$ 100 / \mathrm{g}$ must have a $\mathrm{Pu}^{238}$ credit of at least $\$ 250 / \mathrm{g}$. On the other hand, if the $\mathrm{Pu}^{238}$ credit is $\$ 267 / \mathrm{g}$ and the processing costs are $\$ 50 / g$, then the highest price a reactor operator would be willing to pay for $\mathrm{Np}^{237}$ is $\$ 100 / \mathrm{g}$, the indifference price of $\mathrm{Np}^{237}$. And if the $\mathrm{Pu}^{238}$ credit is $\$ 324 / \mathrm{g}$ and the processing costs are $\$ 100 / \mathrm{g}$, the indifference price of $\mathrm{Np}^{237}$ is again $\$ 100 / \mathrm{g}$.

The total cost of producing transuranium isotopes from target materials can, therefore, be subdivided into the target indifference price and the processing costs; but the effect of processing costs on the target indifference price must be known before a reactor operator can determine whether he can afford to produce transuranium isotopes from target materials. Apart from the processing costs, the factors that go into determining the target indifference price are (1) the cost of target depletion, (2) the product credit (which may include a product purity correction), (3) the irradiation cost, and (4) the inventory costs of target and product. The processing costs, on the other hand, are made up of (1) the encapsulation cost, (2) fuel displacement cost, (3) shipping and storage costs, (4) recovery costs, (5) out-of-reactor decay costs, and (6) interest on the working capital required. It should be noted that the processing costs in this study are parameterized because both the future scale of target material processing and the likely technology are unknown.

The Cost of Target Depletion. After the target is loaded into a reactor, the target becomes depleted at a rate proportional to its cross section and the reactor flux level. The product formed as a result of target depletion may, in turn, be depleted because of further neutron absorptions or because of radioactive decay (short half-life). 
When a product has a short half life or a large cross section, short irradiations are required to maximize the production of that product. For example, Figure 15 shows the depletion of $\mathrm{Np}^{237}$ and the formation of $\mathrm{Pu}^{238}$ as a function of exposure. Since $\mathrm{Pu}^{238}$ has a long half life (89 years) but a large absorption cross section (400 barns), the maximum amount of $\mathrm{Pu}^{238}$ recoverable from a single 4-year irradiation at a flux of $2 \times 10^{13}$ is $28 \%$ of the original $\mathrm{Np}^{237}$ target. However, if a shorter irradiation time is usedsay 1 year-36\% of the original $\mathrm{Np}^{237}$ target could be converted during four successive irradiations (three recycles) of the target. This simply points out that in producing $\mathrm{Pu}^{238}$ from $\mathrm{Np}^{237}$ at a $\mathrm{flux}$ of $2 \times 10^{13}$ neutrons $\mathrm{cm}^{-2} \mathrm{sec}^{-1}$, the maximum rate of production occurs at the beginning of the irradiation.

If target material costs are high, short irradiations with a high percentage of target conversion may, with recycle, result in minimum production costs; but, at the same time, the encapsulation and recovery costs associated with recycling the target must be considered. For if these costs are high, it may be more economical to adopt long continuous irradiation. Thus a balance must be struck between the cost involved in recycling and the reduced target conversion associated with a long continuous irradiation.

Product Purity and Credit. Another factor affecting optimum operating conditions is the desired purity of the product. In the case of $\mathrm{Np}^{237}$ targets being converted into $\mathrm{Pu}^{238}$ (see Figure 15), short irradiations are desirable in order to reduce the formation of the higher plutonium isotopes. But in the production of $\mathrm{Cm}^{244}$. longer irradiations are attractive because $\mathrm{Cm}^{242}$, with its short half life, quickly comes to equilibrium, while the $\mathrm{Cm}^{244}$ concentration continually increases.

Irradiation Cost. The cost of irradiation-namely, the cost of neutrons-is essentially the cost of the additional reactor enrichment required to supply neutrons for converting the target into a 
Figure 15. THE Np ${ }^{237}$ TARGET DEPLETION AND THE Pu ${ }^{238}$ PRODUCT FORMATION IN A SIMULATED WATER REACTOR AT A FLUX LEVEL OF $2 \times 10^{13}$ NEUTRONS $\mathrm{Cm}^{-2} \mathrm{Sec}^{-1}$

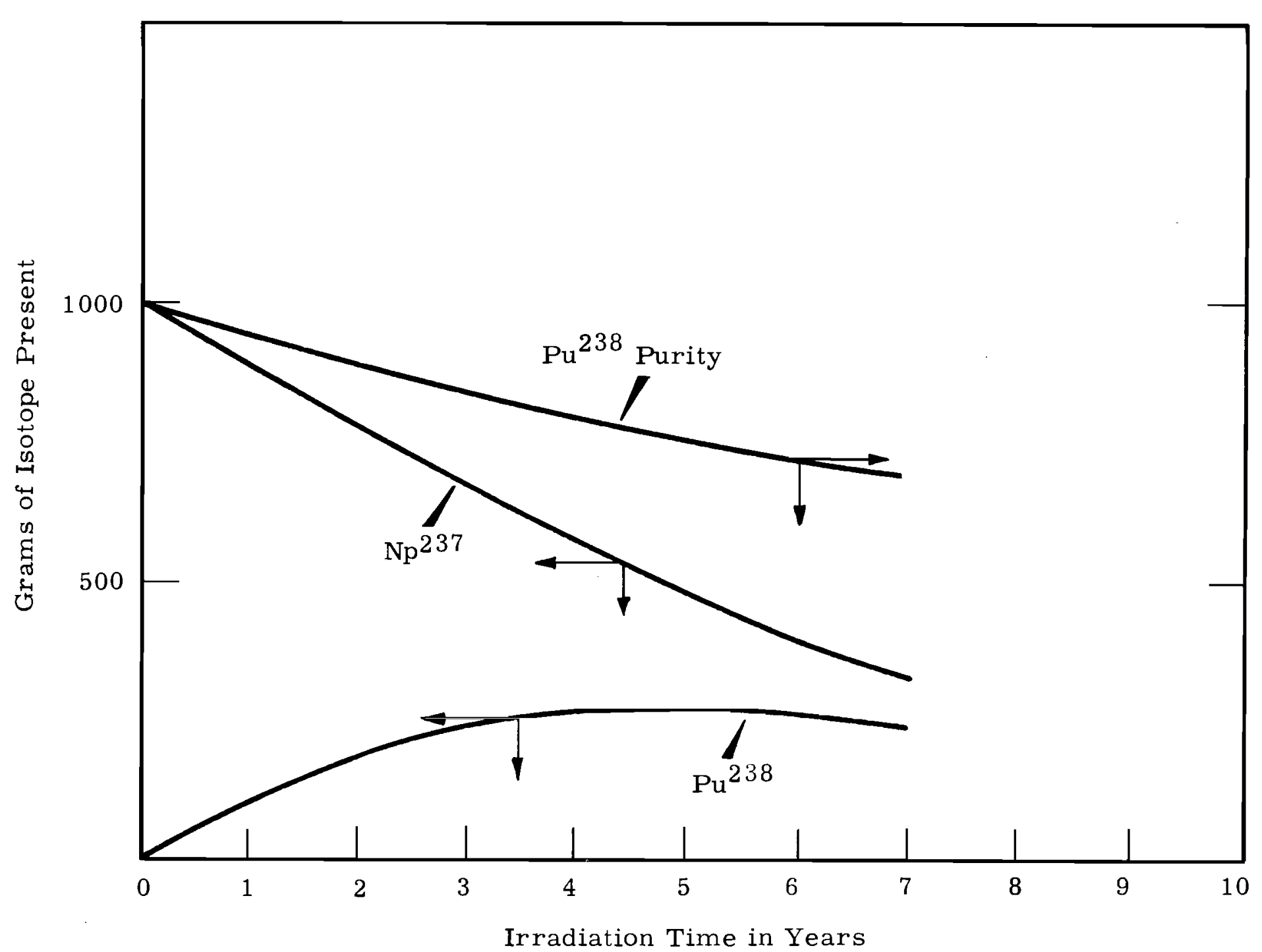

Irradiation Time in Years 
product, or the cost of diverting available neutrons from one product to another. The calculations used in this study were performed in such a way that the reactor flux level and the neutron spectrum of the power reactors considered were not appreciably altered. But this surely does not represent the optimum situation for very many target-product combinations; special reactors may have more attractive neutron spectra and charge-discharge facilities than power reactors.

Inventory Cost. Both during the irradiation and during the pre- and postirradiation times, interest is paid on the investment in the target material and the product formed. As is generally known, the assessment of inventory charges is complicated by the isotopic transmutation process. In this study, the QUICK $(10)$ cost code accounts for these charges with significant rigor.

Encapsulation Cost. The encapsulation cost per unit of target material varies immensely with the target or product properties. (12) Encapsulating targets that contain americium is one example of how a product property can affect encapsulation costs. The radiation of such targets results in a heat-transfer difficulty due to the high decay heat flux which $\mathrm{Cm}^{242}$ is capable of producing. Table IX shows the heat which must be removed from a cubic centimeter of the original target containing various quantities of $\mathrm{Am}^{241}$. The data in Table IX are based on the assumption that $10 \%$ of the americium in the original target will exist as $\mathrm{Cm}^{242}$. Since 144 watts $/ \mathrm{cm}^{3}$ (see Table IX) is approximately what a fuel element in a power reactor would produce during full power operation, a reactor cooling problem would exist if the reactor were to shutdown. The encapsulating problem could be solved in one of two ways: by diluting the original $\mathrm{Am}^{241}$ concentration to within 
TABLE IX

HEAT GENERATED BY CURIUM ${ }^{242}$ PRODUCED DURING THE IRRADIATION OF A TARGET CONTAINING AMERICIUM ${ }^{241}$

Watts/cm From $\mathrm{Cm}^{242} \alpha$ Decay at $10 \%$ of Original Am ${ }^{241}$ Target Concentration

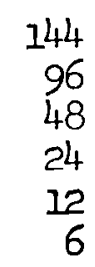

$\frac{\text { Quantity of } \mathrm{Am}^{241} \text { in Original Target }}{\left(\mathrm{g} / \mathrm{cm}^{3}\right)}$

12

8

4

1

0.5 
acceptable heat transfer limits, which would increase encapsulation costs, or by supplying special cooling devices.

Fuel Displacement Cost. The use of a target element that displaces a power-producing fuel rod decreases the total reactor power output by the percent of fuel volume displaced, even though some target materials will produce decay isotopes that have significant quantities of heat. However, target elements may not always require the displacement of power-producing fuel rods; target elements could be placed in existing void areas or around the fringe of the core; they may even be used as control devices if the target cross sections have an appropriate magnitude.

Recovery Costs. The separation of target and product material is a major component of processing costs, and is largely dependent on the amount of target and product processed.

Shipping and Storage Costs. Shipping costs will vary with the amount delivered, the heat removable capability required, and the radioactivity of the target and product.

Out-of-Reactor Target and Product Decay Costs. A cost is involved in the decay losses of the target and product before irradiation and during the postirradiation processing. $\mathrm{Cm}^{244}$, for example, which has a 18-year half-life, decays about $4 \%$ a year. At a price of $\$ 1000 / \mathrm{g}$, the cost per kilogram would be $\$ 40,000$ a year for the 40 grams of $\mathrm{Cm}^{244}$ lost by decay.

THE IMPACT OF TRANSURANIUM ISOTOPE CREDITS

ON FUEL-CYCLE COSTS OF POWER REACTORS

If a credit is assigned to a transuranium isotope, the fuel cycle cost of a power reactor will decrease as the production rate of the isotope increases. And if the assigned credit is high enough, 
a reactor operator might be willing to alter his fuel cycle to increase the production of the isotope. However, because of the normal workings of a free market, it is unlikely that a very high credit would exist over a long period. Such a credit would probably exist only during such special cases as Government contracts for initial amounts of transuranium isotopes.

Even so, Table $X$ shows that the impact of transuranium isotopes credits on the normal fueling methods of power reactors is not insignificant. For instance, when the market price of $\mathrm{Np}^{237}$ is $\$ 100 / \mathrm{g}$ (see Case 3 in Table $\mathrm{X}$ ), the fue 1 -cycle costs of the PWR burning slightly enriched uranium and of the PWR recycling the plutonium formed in a previous uranium cycle, are reduced by 1.41 and $1.61 \mathrm{mi} 11 \mathrm{~s} / \mathrm{kWhe}$ respective1y; and the fue 1 cycle costs of the other two fueling methods*are reduced by about $0.1 \mathrm{mi} 11 / \mathrm{kWhe}$, which, to a $1000 \mathrm{MW}$ e power plant, is equal to about $\$ 750,000$ per year. Case 9 in Table $X$ shows that to obtain the same reduction in a slightly enriched uranium fueled reactor, $\mathrm{Am}^{243}$ and $\mathrm{Cm}^{244}$ would have to have credits of $\$ 100 / \mathrm{g}$ and $\$ 500 / \mathrm{g}$, respectively. However, if plutonium is recycled (Case 10 under the PWR-Plutonium column in Table $X$ ) only a $\$ 250 /$ g credit for $\mathrm{Cm}^{244}$ and no credit for $\mathrm{Am}^{243}$ are required to obtain the $0.1 \mathrm{mill} / \mathrm{kWh}$ e reduction. A credit for $\mathrm{Cm}^{242}$ as we11 as for $\mathrm{Cm}^{244}$ would provide even more incentive to recycle plutonium, because plutonium recycle increases the production of both $\mathrm{Cm}^{242}$ and $\mathrm{Cm}^{244}$. Taking into account the effective indifference price of a plutonium composition (Case 15 in Table IX), one can see that a $\$ 500 / \mathrm{g}$ credit for $\mathrm{Cm}^{244}$ implies a $\$ 50 / \mathrm{g}$ credit for $\mathrm{Pu}^{242}$, which is now considered a poison in thermal reactors; a credit would also be given to $U^{236}$, a byproduct of a reactor that burns $U^{235}$. (See Figure 12 on page 39. )

* The BWR costs are based on data in the General Electric report GEAP-4476, entitled 1000 MWe Boiling Water Reactor Plant Feasibility Study ( 3 vols). 


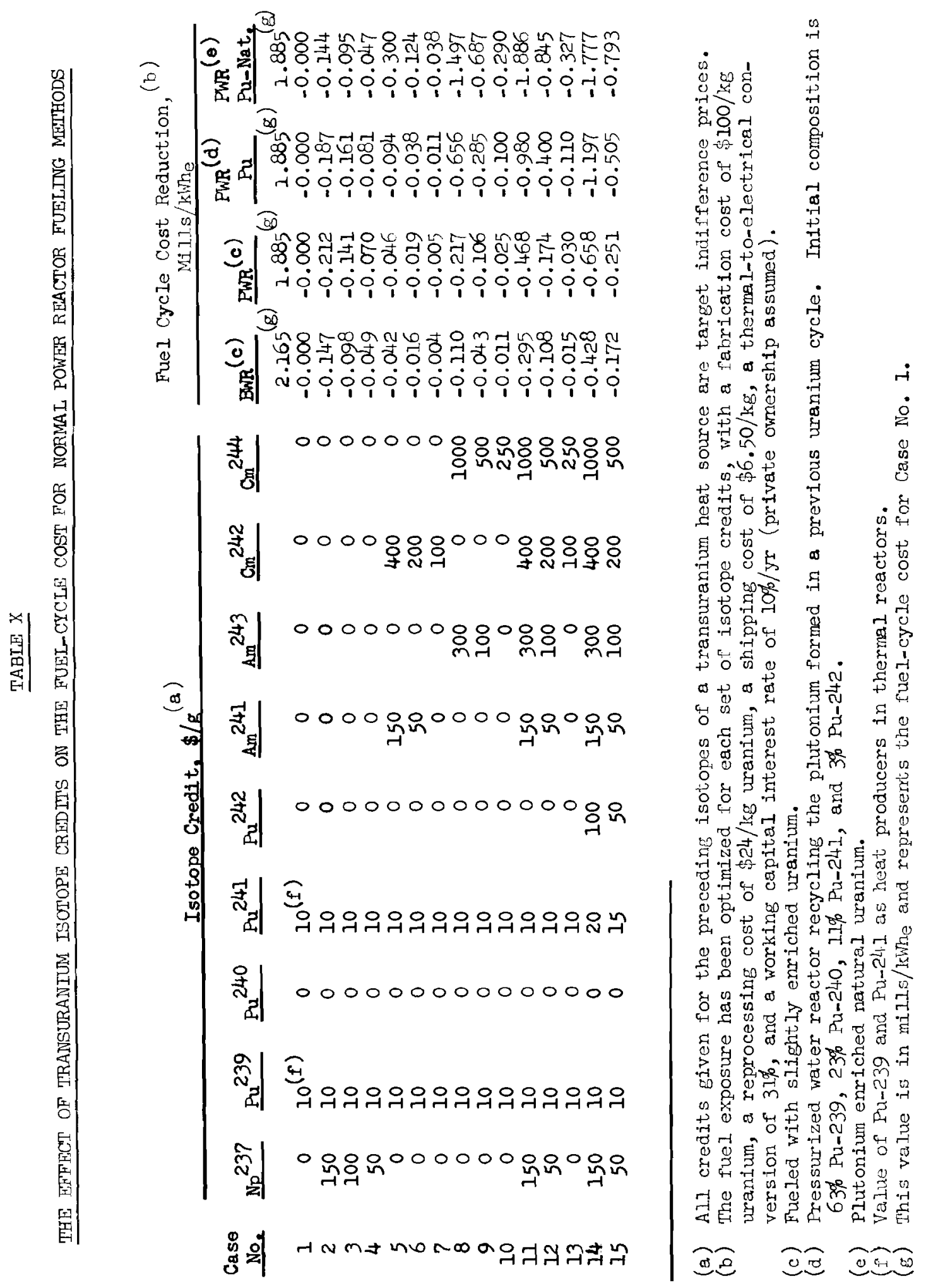


Table XI indicates the effect of various transuranium isotope credits on power reactor fuel-cycle costs when "normal" fueling methods have been altered to increase the production of transuranium isotopes. The three fueling schemes listed in Table XI were discussed earlier in connection with both Figure 5 (see page 20), where it was shown that more fully enriched uranium would produce greater amounts of $\mathrm{Np}^{237}$, and Figure 8 (see page 27) where the $\mathrm{Cm}^{244}$ production was indicated for various fueling schemes.

It will be noted in Table XI that in Case No. 1 (where there are no credits for transuranium isotopes) the fuel-cycle costs of the three special fueling methods are definitely not competitive with the fuel-cycle costs shown in Case $I$ of Table $X$ for the "normal" fueling methods. And when credits are given for transuranium isotopes, only one fueling method in Table XI-that of a PWR burning plutonium in a zirconium matrix-is competitive with that of the PWR burning slightly enriched uranium indicated in Table $X$. Furthermore, this special fueling method is competitive in on $1 y 6$ of the 15 cases 1isted-name1y, Cases 8, 9, 11, 12, 14, and 15 . Moreover, in each of these six cases the $\mathrm{Cm}^{244}$ credit alone is either $\$ 500$ or $\$ 1000$ per gram.

The americium and curium credits in Table XI do not apply to the last column, which shows the fuel-cycle cost reductions of a PWR burning fully enriched uranium (93\% wt. $\mathrm{U}^{235}$ ). As mentioned earlier (see page 19), this fueling scheme will produce $\mathrm{Pu}^{238}$ that is $65 \%$ pure, and will do so directly, without requiring $\mathrm{Np}^{237}$ to be encapsulated before irradiation. It should be noted in Table XI that even in Cases 11 and 14 , where the $\mathrm{Pu}^{238}$ credit is at a maximum of $\$ 250$ per gram and causes the greatest fuel-cycle cost reduction, the fuel-cycle costs of this special PWR fueling method are still more than $1.0 \mathrm{mill} / \mathrm{kWhe}$ higher than the fuel-cycle costs of the PWR fueling method that burns slightly enriched uranium. (See Cases 11 and 14 of the next-to-last column in Table $x$.) 


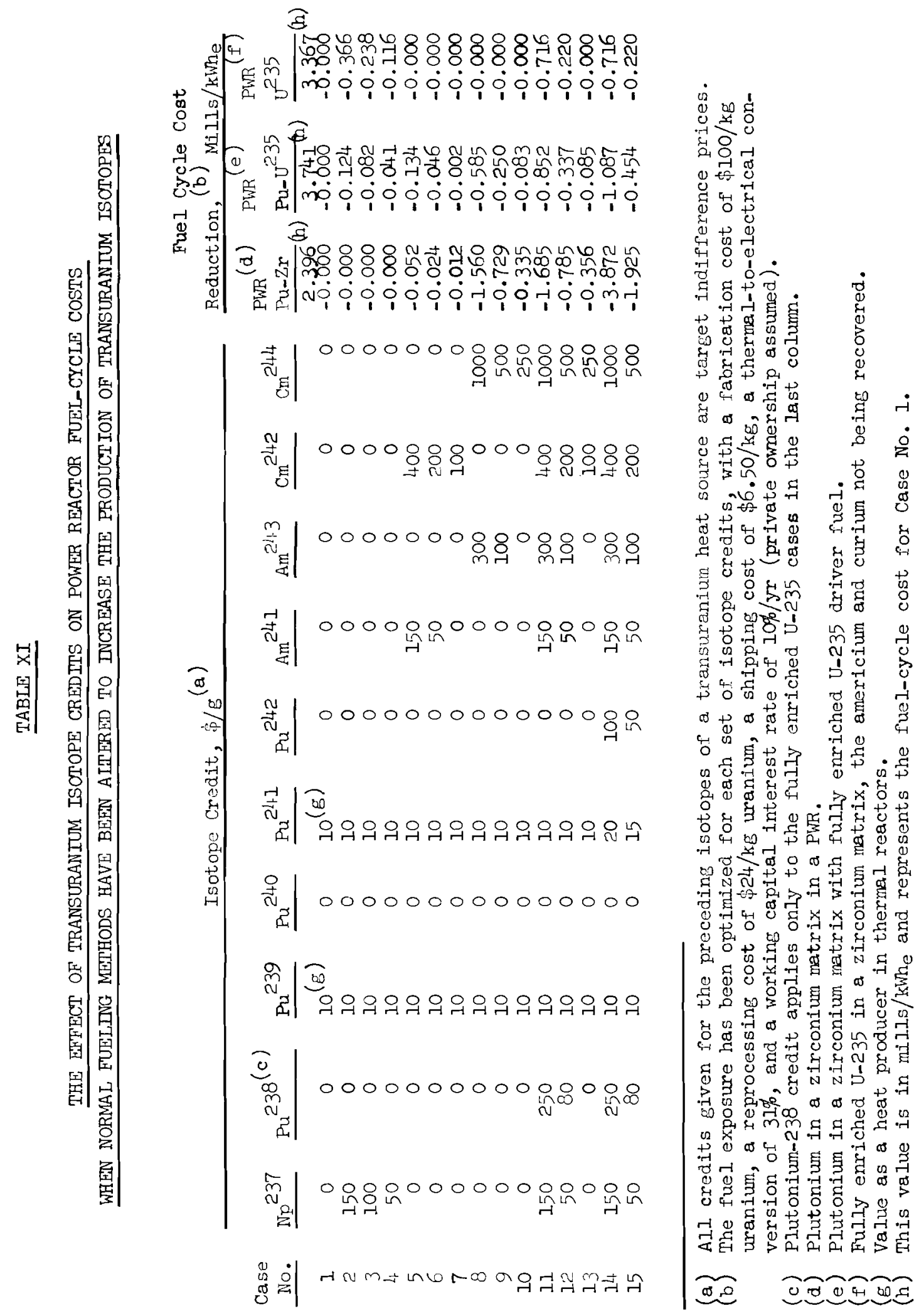


THE IMPACT OF CROSS SECTION UNCERTAINTIES

ON THE COMPUTED PRODUCTION

OF TRANSURANIUM ISOTOPES

The greatest uncertainties affecting the computed production of transuranium isotopes are the alpha values of $\mathrm{Pu}^{239}$ and $\mathrm{Pu}^{241}$ as well as the resonance integrals of americium, curium, $\mathrm{U}^{236}$, and $\mathrm{Np}^{237}$. (The other nuclear properties of the isotopes considered in the ALTHAEA computional sequence are well enough known that their perturbation analysis can be dispensed with.) Table XII shows how variations in nuclear properties affect isotopic concentrations when the reactivity limited fuel exposures are 18 $\mathrm{MWd} / \mathrm{kg}$. Because the fuel exposures are reactivity limited, the amount of supplementary $U^{235}$ enrichment varies in Cases 2 and 3 , causing slight changes in the amount of plutonium burned. In all cases, the initial plutonium enrichment is $1.25 \%$ and consists of 63\% $\mathrm{Pu}^{239}, 23 \% \mathrm{Pu}^{240}, 11 \% \mathrm{Pu}^{241}$, and $3 \% \mathrm{Pu}^{242}$.

The first three cases in Table XII indicate that a variation in the alpha of plutonium has only a moderate effect on the estimated $\mathrm{Cm}^{244}$ produced. The reason for this is that if the estimated plutonium alpha is higher than it should be, the required reduction in $\mathrm{U}^{235}$ enrichment will cause more plutonium reactions, which form more $\mathrm{Cm}^{244}$. On the other hand, if the estimated plutonium alpha is lower than it should be, the required increase in $U^{235}$ enrichment will cause fewer plutonium reactions, which form less $\mathrm{Cm}^{244}$.

Except for having a constant $U^{235}$ enrichment, Cases 4 and 5 are the same as Cases 3 and 2 , respectively. Comparing the $\mathrm{Cm}^{244}$ concentrations in Cases 4 and 5 with those in Cases 3 and 2 , one finds that a constant $U^{235}$ enrichment amplifies the effect of a $10 \%$ change in the alpha of plutonium. 


\section{TABLE XII}

\section{THE FFFECT OF VARIED NUCLFAR PROPERTIES ON ISOTOPIC CONCENTRATIONS AT DISCHARGE}

(Fuel Exposure is $18 \mathrm{MWd} / \mathrm{kg}$ )

\begin{tabular}{|c|c|c|c|c|c|c|c|c|c|c|c|c|c|}
\hline \multirow[b]{2}{*}{$\begin{array}{l}\text { Case } \\
\text { No. }\end{array}$} & \multirow[b]{2}{*}{ Nuclear Property Varied } & \multirow{2}{*}{$\begin{array}{c}0^{235} \\
\text { Enrich- } \\
\text { ment, } \\
\text { Wt } 8 \\
\end{array}$} & \multicolumn{11}{|c|}{ Isotope Concentrations, $\mathrm{g} / \mathrm{MT}$} \\
\hline & & & $\underline{0}^{236}$ & $\underline{\mathrm{Np}^{237}}$ & $\underline{\mathrm{Pu}^{238}}$ & $\mathrm{Pu}^{239}$ & $\mathrm{Pu}^{240}$ & $\underline{P u}^{241}$ & $\underline{P u}^{242}$ & $\mathrm{Am}^{241}$ & $\mathrm{Am}^{243}$ & $\mathrm{Cm}^{242}$ & $\mathrm{~cm}^{244}$ \\
\hline 1 & None & 2.94 & 1279 & 239 & 191 & 7109 & 3991 & 2397 & 968 & 150 & 245 & 36 & 62 \\
\hline 2 & $\begin{array}{l}\text { Alpha of } \mathrm{Pu}^{239} \text { and } \\
\mathrm{Pu}(\mathrm{a})\end{array}$ & 2.34 & 903 & 226 & 189 & 6670 & 3819 & 2263 & 960 & 138 & 253 & 37 & 67 \\
\hline 3 & $\begin{array}{l}\text { Alpha of } \mathrm{Pu}^{239} \text { and } \\
\mathrm{Pu}^{241} \text { increased } 10 \%(\mathrm{a})\end{array}$ & 3.53 & 1651 & 261 & 198 & 7421 & 4140 & 2519 & 1002 & 163 & 252 & 37 & 64 \\
\hline 4 & $\begin{array}{l}\text { Alpha of } \mathrm{Pu}^{239} \text { and }(\mathrm{b}) \\
\mathrm{Pu}^{241} \text { increased } 10 \%\end{array}$ & 2.94 & 1306 & 247 & 193 & 9070 & 4237 & 2471 & 1067 & 150 & 267 & 37 & 68 \\
\hline 5 & $\begin{array}{l}\text { Alpha of } \mathrm{Pu}^{239} \text { and } \\
P u^{24 I} \text { decreased } 10 \%\end{array}$ & 2.94 & 1253 & 232 & 190 & 7152 & 3749 & 2324 & 877 & 149 & 226 & 35 & 56 \\
\hline 6 & $\begin{array}{l}\text { Cross section of } \mathrm{Am}^{241} \\
\text { and } \mathrm{Am}^{243} \text { increased } 20 \%\end{array}$ & 2.94 & 1279 & 239 & 201 & 7113 & 3991 & 2398 & 967 & 135 & 235 & 42 & 71 \\
\hline 7 & $\begin{array}{l}\text { Cross section of } \mathrm{Am}^{241} \\
\text { and } \mathrm{Am}^{243} \text { Increased } 50 \%\end{array}$ & 2.94 & 1279 & 239 & 214 & 7117 & 3991 & 2399 & 965 & 116 & 219 & 49 & 86 \\
\hline 8 & $\begin{array}{l}\text { Cross section of } \mathrm{cm}^{242} \\
\text { and } \mathrm{Cm}^{244} \text { increased } 100 \%\end{array}$ & 2.94 & 1279 & 239 & 191 & 7109 & 3991 & 2397 & 968 & 150 & 245 & 36 & 61 \\
\hline 9 & $\begin{array}{l}\text { Cross section of } \mathrm{Cm}^{242} \\
\text { and } \mathrm{Cm}^{244} \text { increased } 400 \%\end{array}$ & 2.94 & 1279 & 239 & 191 & 7109 & 3991 & 2397 & 968 & 150 & 245 & 36 & 61 \\
\hline 10 & $\begin{array}{l}\text { Cross section of } 0^{236} \\
\text { increased by } 20 \%\end{array}$ & 2.94 & 1262 & 256 & 192 & 7113 & 3991 & 2398 & 968 & 150 & 246 & 36 & 62 \\
\hline 11 & $\begin{array}{l}\text { Cross section of } \mathrm{Np}^{237} \\
\text { increased by } 20 \%\end{array}$ & 2.94 & 1279 & 234 & 196 & 7113 & 3991 & 2398 & 968 & 150 & 246 & 36 & 62 \\
\hline
\end{tabular}

(a) With 0235 enrichment adjusted to the desired reactivity limited exposure.

(b) W1th $0^{235}$ enrichment held constant. 
The remaining cases in Table XII show how the production of isotopes would be affected if additional resonances were present. Cases 6 and 7 show that when the americium cross sections are increased by $20 \%$ and $50 \%$, the curium concentrations increase about $16 \%$ and $37 \%$, respective $1 y$. In Cases 8 and 9 , both the $\mathrm{Cm}^{242}$ and the $\mathrm{Cm}^{244}$ cross sections are arbitrarily increased $100 \%$ and $400 \%$ so as to reflect possible uncertainties in the resonance data. Case 8 shows that a $100 \%$ increase in the curium cross sections reduces the $\mathrm{Cm}^{244}$ concentration on $1 \mathrm{y} 2 \%$ and the $\mathrm{Cm}^{242}$ concentration even 1ess. Case 9 shows that a $400 \%$ increase in the curium cross sections has the same effect as the $100 \%$ increase in Case 8 . In the final two cases are shown the changes in the estimated $\mathrm{Np}^{237}$ concentrations when the $\mathrm{U}^{236}$ or $\mathrm{Np}^{237}$ cross sections are increased by $20 \%$. In Case 10 , the effect of the larger $\mathrm{U}^{236}$ cross section is to increase the $\mathrm{Np}^{237}$ concentration by $7 \%$. But in Case 11 , the effect of the larger $\mathrm{Np}^{237}$ cross section is to reduce the $\mathrm{Np}^{237}$ concentration by $3 \%$. 
,

• 
BNWL -223

\section{APPENDIX A}

COMPARISON OF ALTHAEA COMPUTER CODE RESULTS

WITH THE RESULTS OF CHEMICAL ANALYSES

OF YANKEE AND VALLECITOS FUEL RODS 


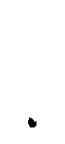


BNWL -223

\title{
APPENDIX A
}

\author{
COMPARISON OF ALTHAEA COMPUTER CODE RESULTS \\ WITH THE RESULTS OF CHEMICAL ANALYSES \\ OF YANKEE AND VALLECITOS FUEL RODS
}

Tables A-I and A-II show how well the results from the ALTHAEA computer code agree with the chemical analyses of Yankee and Vallecitos fuel rods. (6) The Yankee data in Table A-I relate to four separate rods, two of which were in the center of a fuel assembly and two near a water gap. The Vallecitos data in Table A-II relate to three different points along a single rod. Since the exact neutron spectrum was not known for these data, the following procedure was used for calculating the neutron spectrum in the ALTHAEA code: (1) the burnup was terminated when the $U^{235}$ concentration in ALTHAEA agreed with the $\mathrm{U}^{235}$ concentration in the chemical analyses, and (2) the coolant density was adjusted so as to produce a plutonium concentration that agreed with the chemical analyses. (Adjusting the coolant density in this way allowed the resonance absorption in $U^{238}$ to be used as a spectrum indicator.)

As shown in Table A-I, the fuel exposures in ALTHAEA fall within the error limits of the exposures determined by cesium analysis. Also, the relative plutonium isotopic composition agrees to within $1 \%$. Of the higher isotopes, $\mathrm{Cm}^{244}$ shows better agreement than $\mathrm{Am}^{241}$ and $\mathrm{Cm}^{242}$, both of which are strongly affected by the power level during the burnup history-which is not well known. As for $\mathrm{Np}^{237}$ production, the ALTHAEA results substantially agree with chemical analysis of the Yankee rods only when the $\mathrm{U}^{236}$ concentration is in substantial agreement. According to calculations both by Pacific Northwest Laboratory and by Westinghouse, 


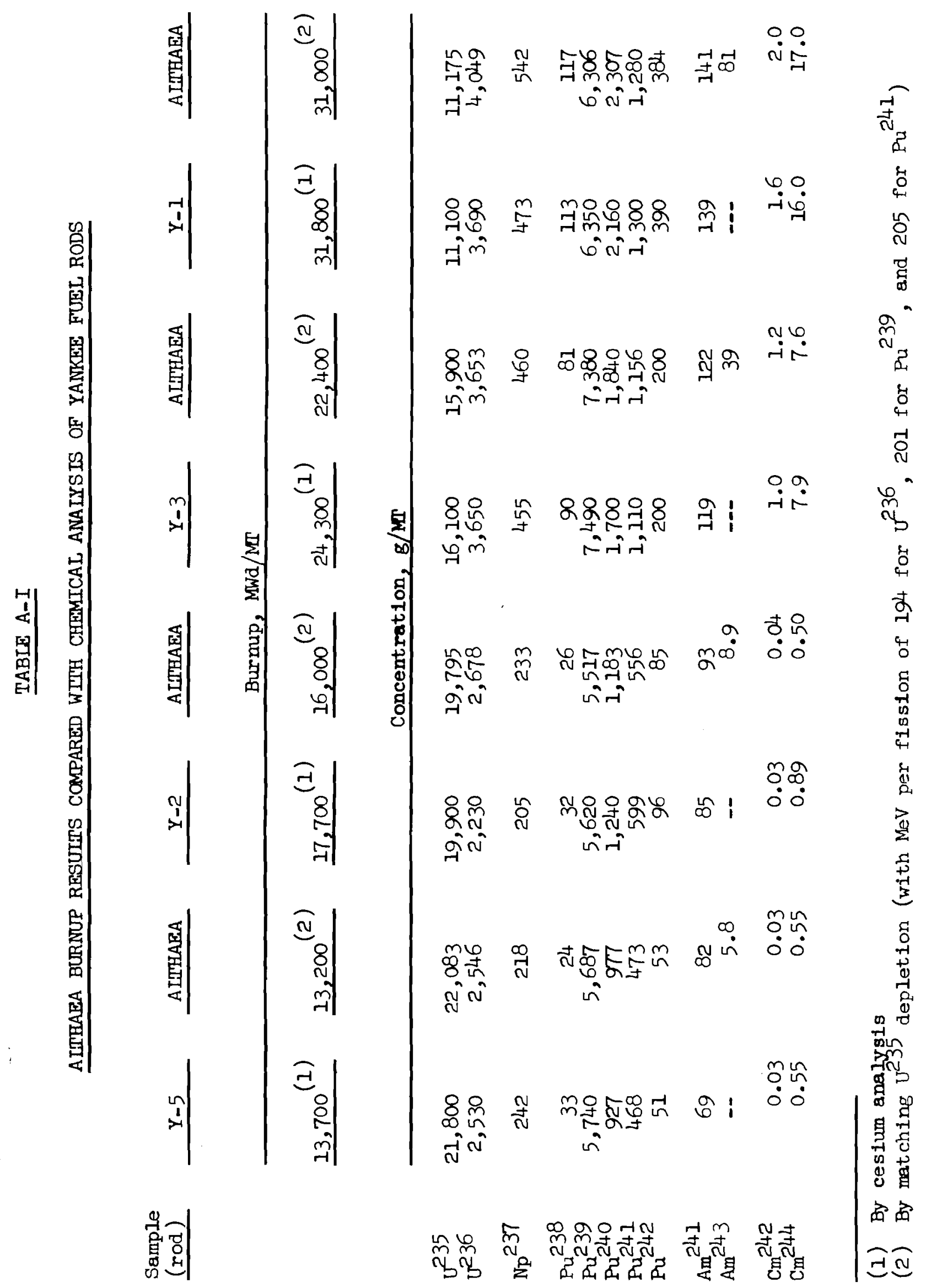




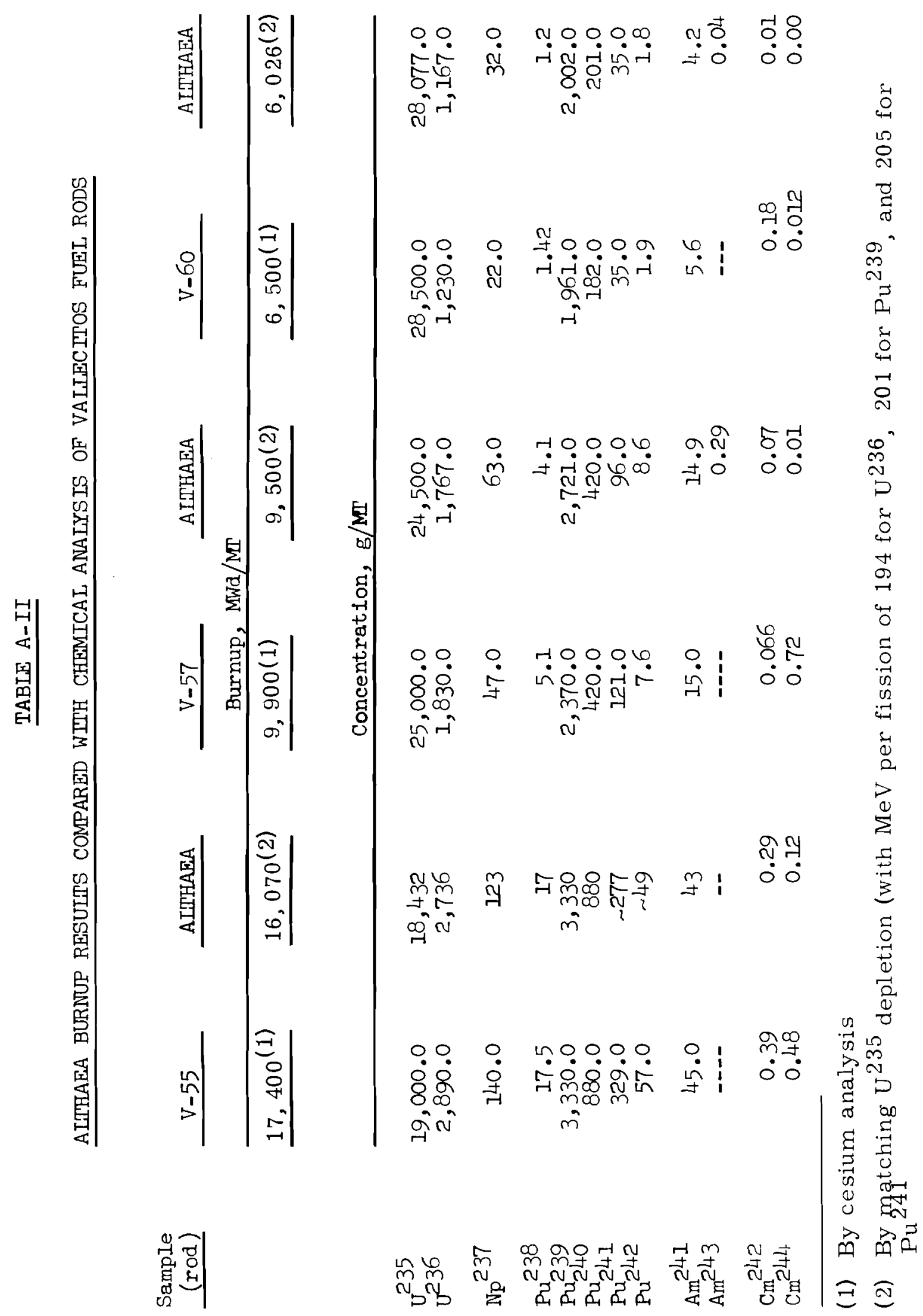


the $\mathrm{U}^{236}$ concentration found by chemical analysis should be higher when the ALTHAEA results differ with the Yankee data. Analysis of the three isotopes $\mathrm{U}^{236}, \mathrm{~Np}^{237}$, and $\mathrm{Pu}^{238}$, each by a different method, has also verified that the alpha for $\mathrm{U}^{235}$ was abnormally 1 ow in the $Y 1$ and $Y 2$ fuel rod samples. This phenomenon has been observed in previous Yankee rod analyses, and is possibly due to local shielding of the $U^{235}$ resonance.

The reason the ALTHAEA vaiues in Table A-II show a lower production of transuranium isotopes than the Vallecitos data is that these data are for a much softer spectrum than those either of Yankee or of recent BWR designs. On the other hand, the production of $\mathrm{Np}^{237}$ indicated by ALTHAEA for low exposures is higher than that found by chemical analysis. The reason may be that in the ALTHAEA code the production of $\mathrm{Np}^{237}$ is primarily due to $n-2 n$ reactions $(60 \%)$, which may be too high for the Vallecitos spectrum. At higher exposures, however, where the $n-2 n$ reactions are not of much account in $\mathrm{Np}^{237}$ production, the difference between ALTHAEA and the chemical analysis is small. Lastly, the discrepancy in curium values is due to the fact that the chemical analysis was in error for the BWR cases. (13) 
BNWL -223

\author{
APPENDIX B \\ SAMPLE COMPUTER PRINTOUT SUMMARY \\ FROM THE REPORT ENTITLED \\ FORMATION OF TRANSURANIUM ISOTOPES IN POWER REACTORS, \\ BNWL-140 REV1
}



PLUTONIUM RECYCLE IN PRESSURIZED WATER REACTOR

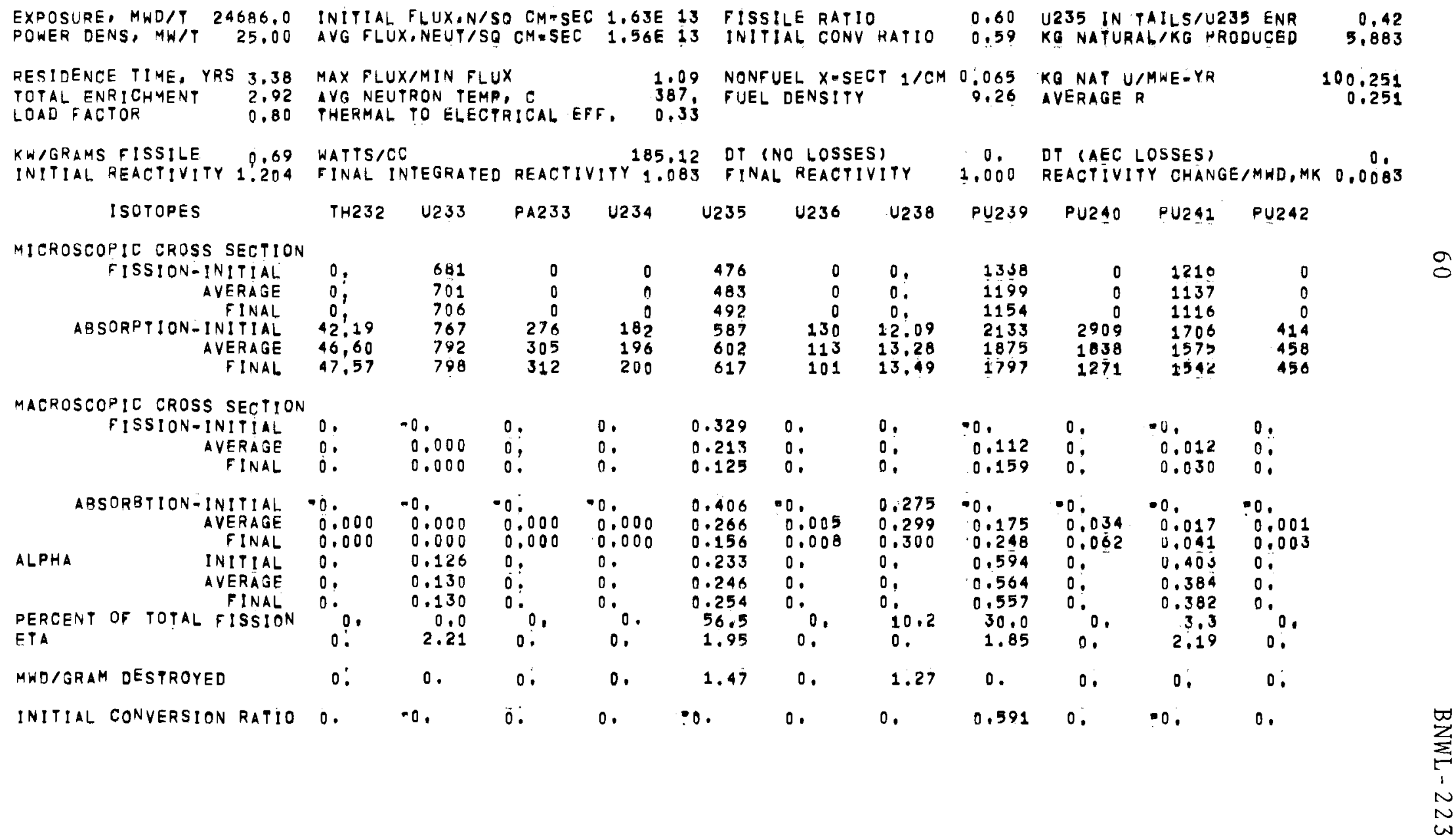




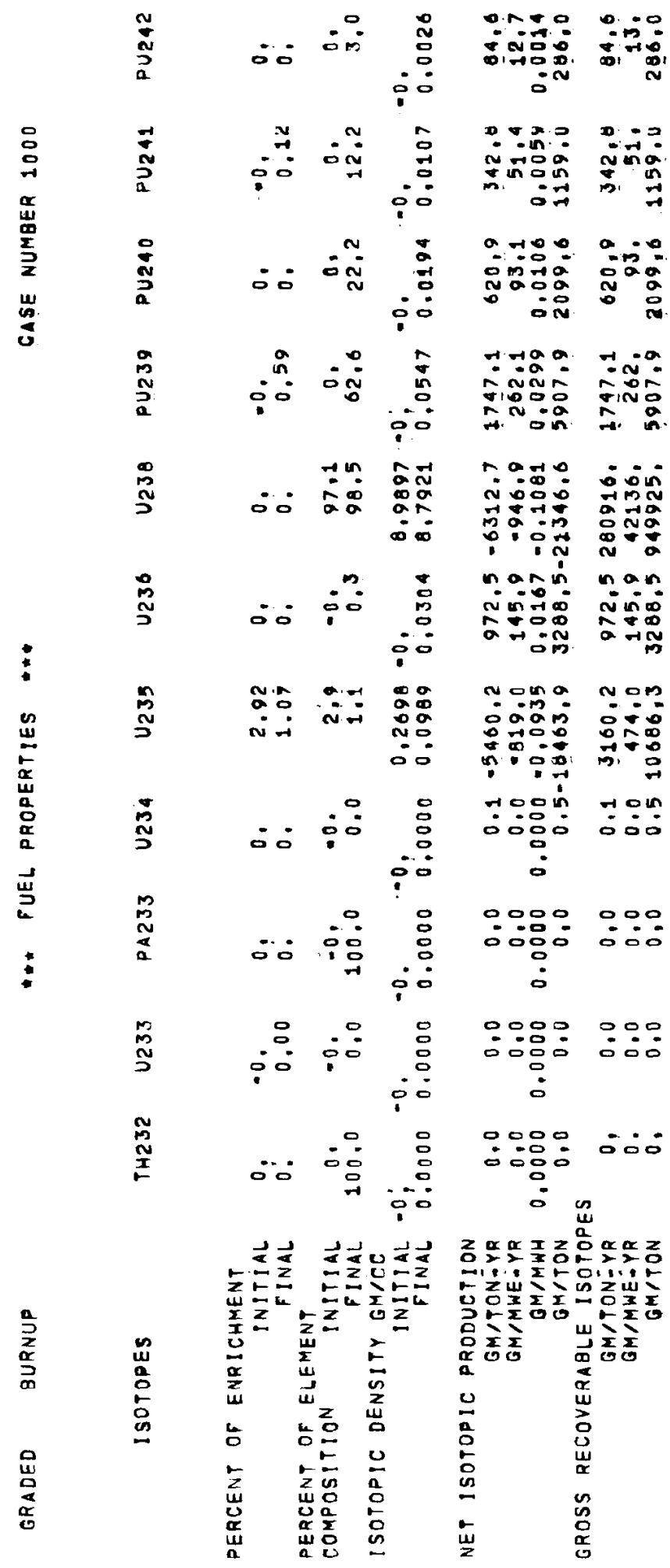




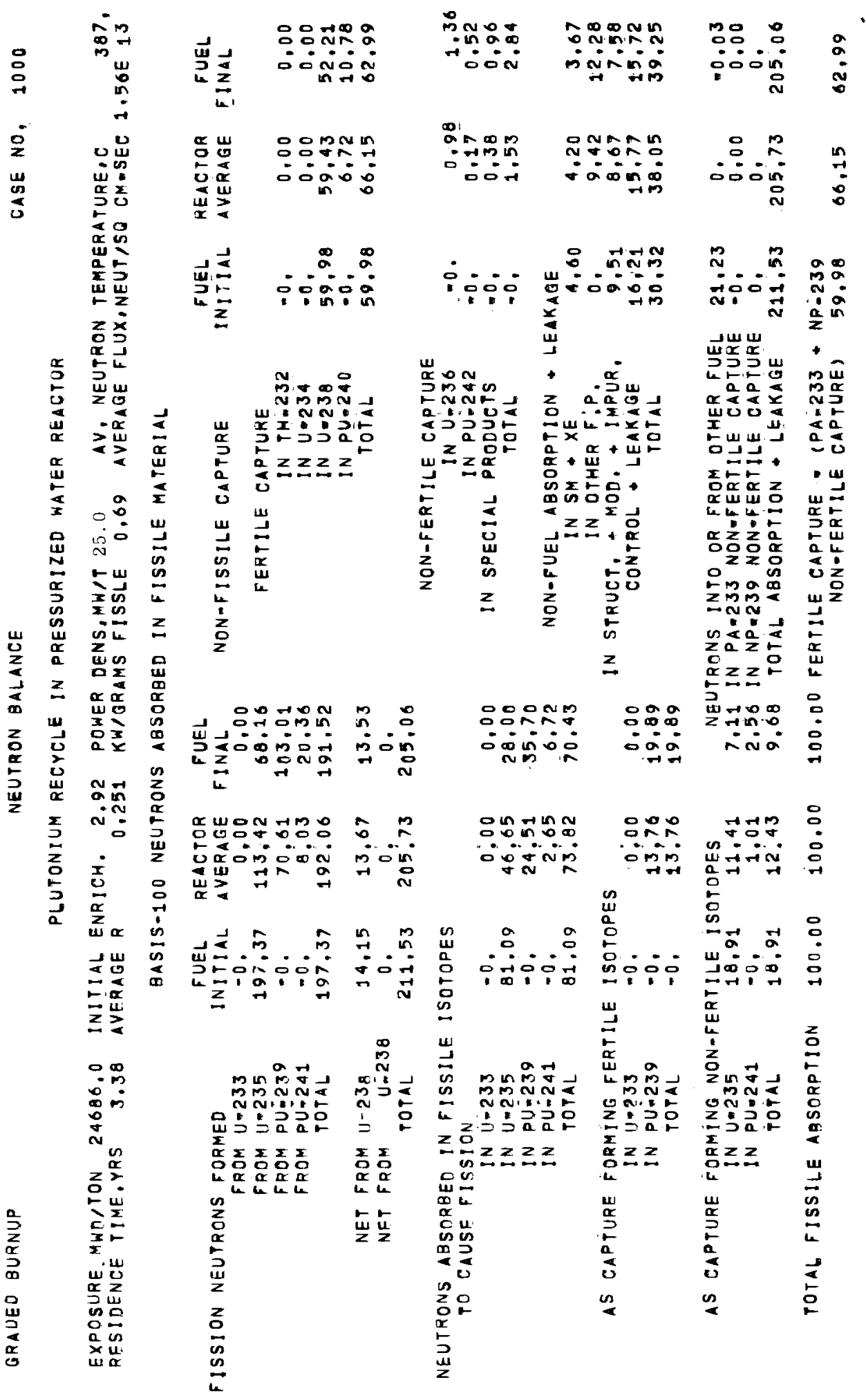




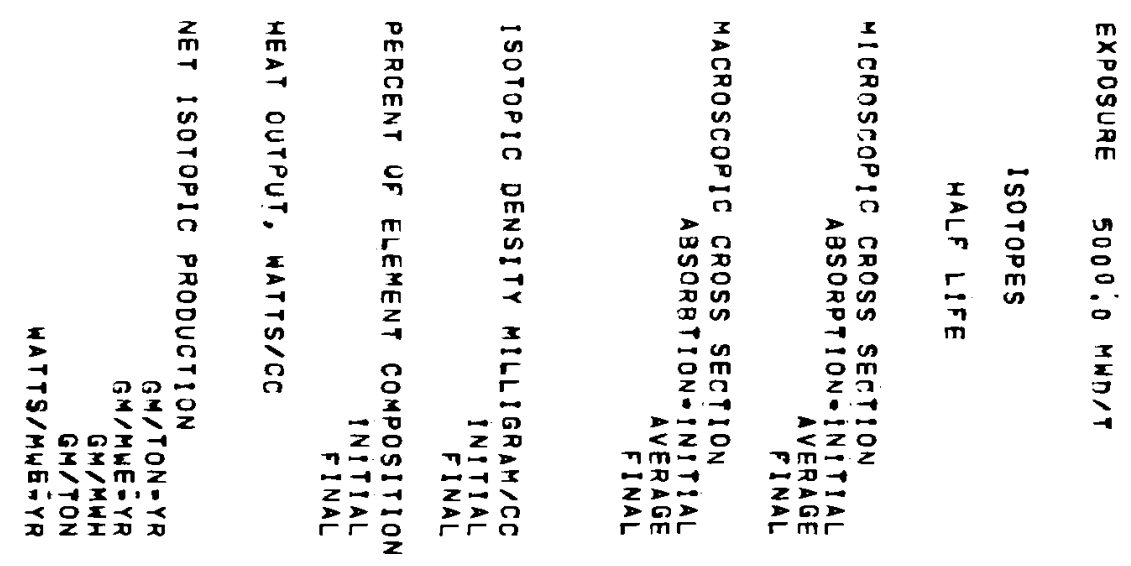

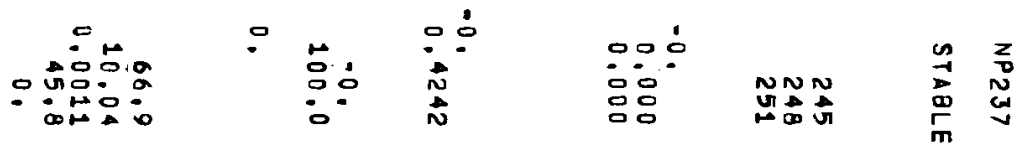

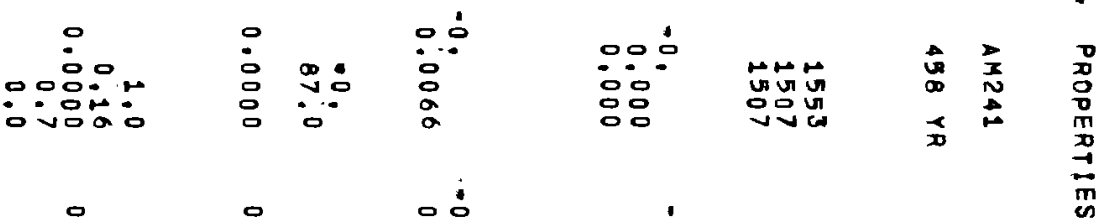

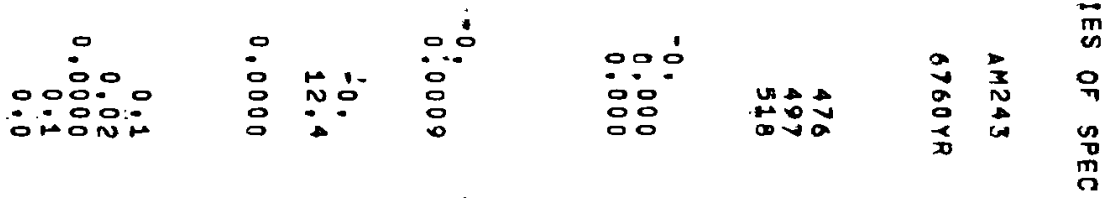

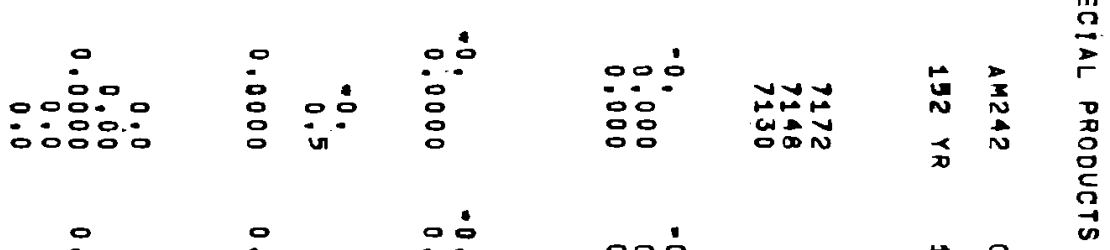

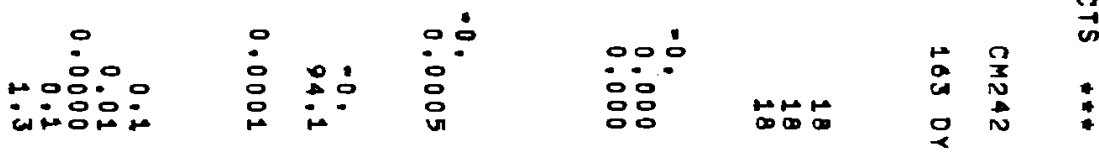

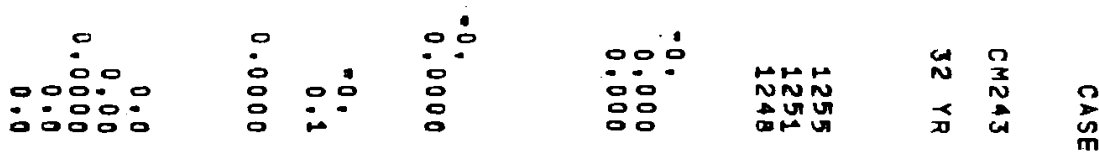

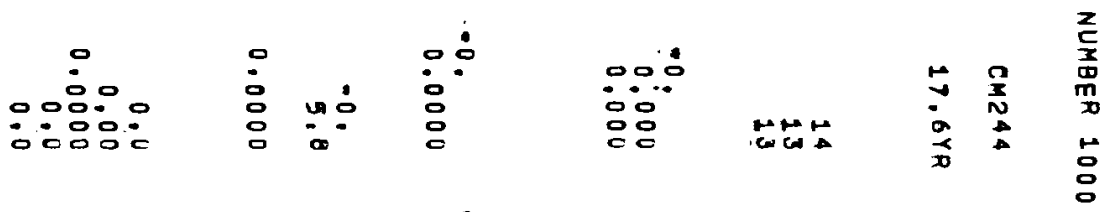

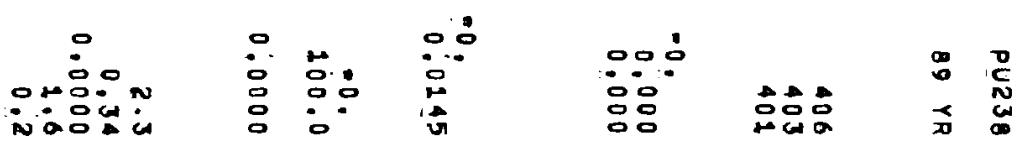

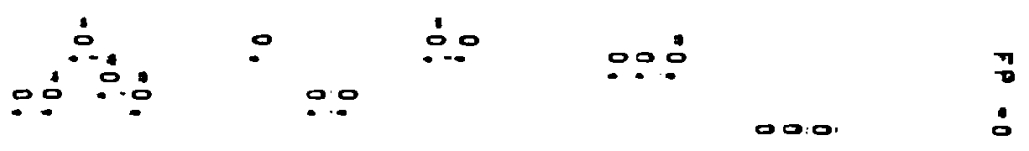


64

BNWL - 223

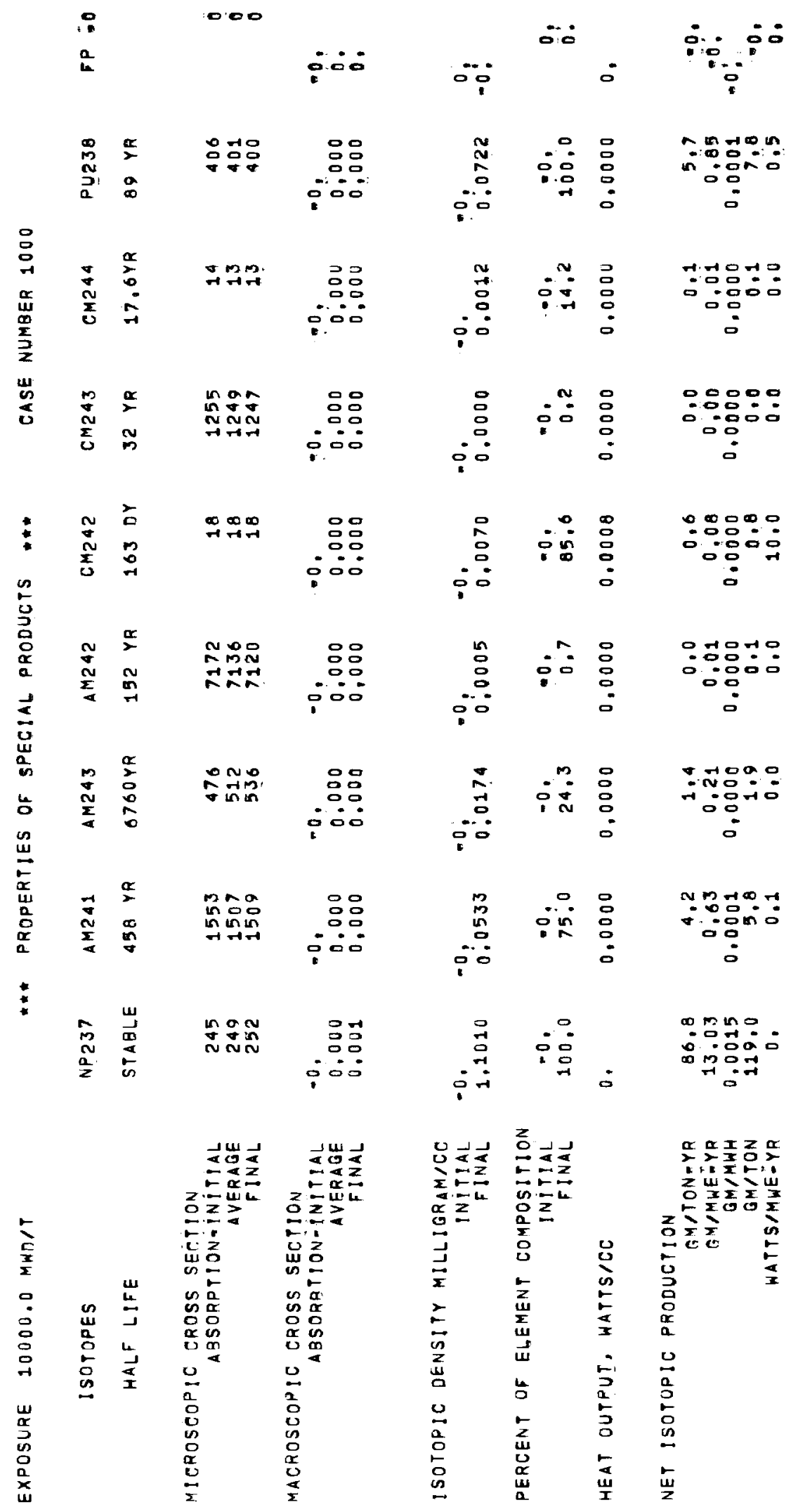




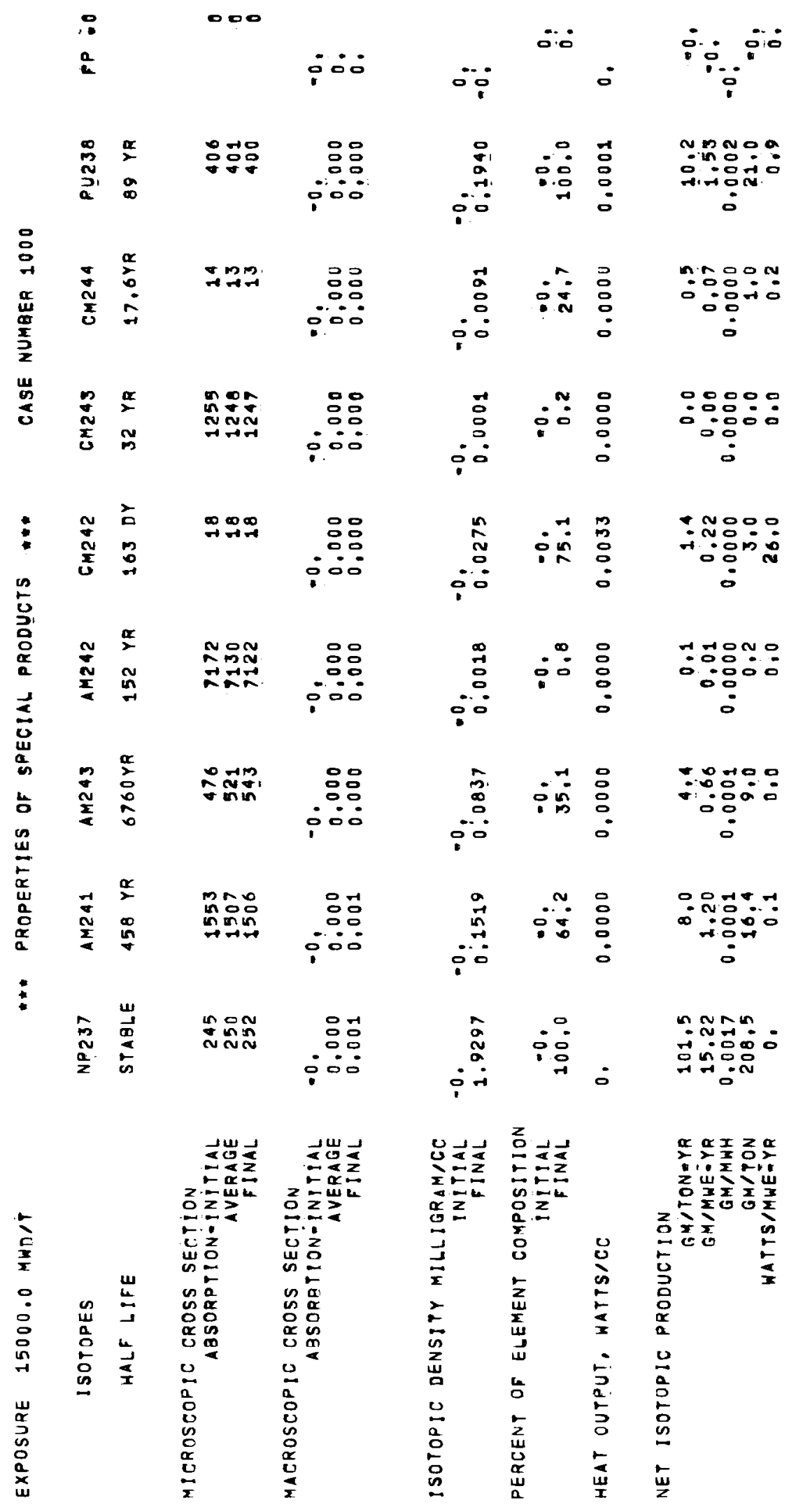




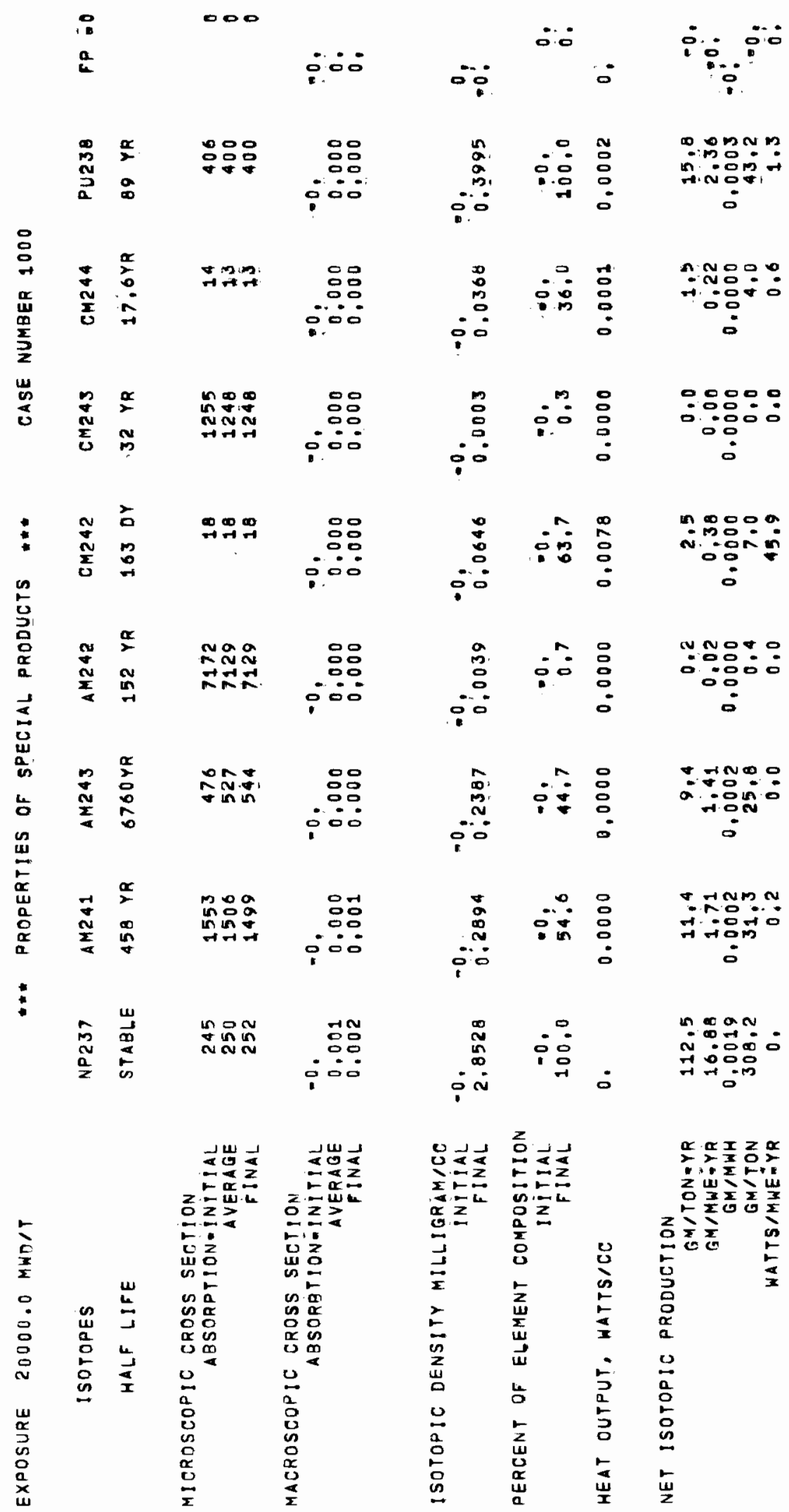


EXPOSURE 24686.0 MWËTY

ISOTOPES

HALF LIFE

MICROSCOPIC CROSS SECTION ABSORPTION INITIAL

AVERAGE
FINAL

MACROSCOPIC CROSS SECTION

ABSORBTION = INITIAL

AVERAGE
FINAL

ISOTOPIC DENSITY MILLIORAM/CC

$$
\text { INITIAL }
$$

PERCENT OF ELEMENT COMPOSITION

$$
\text { IN TITAL }
$$$$
\text { FINAL }
$$

HEAT OUTPUT, WATTS/GC

NET ISOTOPIC PRODUCTION

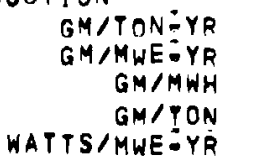

** PROPERTIES OF gPECIAL PRODUCTS

NP2J7

AM241

AM243

$4 M 242$

CH242

163 OY

$\mathrm{CM}_{243}$

$32 Y R$

CM244

$17.6 Y \mathrm{~F}$

PUZ38 FP:O

458 YR

6760YR

152 YR

$\begin{array}{ll}18 & 1255 \\ 18 & 1248\end{array}$

1248
1249

14
13
13

$-0$.

$=0.000$

0.000
0.000

$=0$.

$\begin{array}{rr}-0.0 & -0,0001 \\ 0.001 & 0.001 \\ 0.002 & 0.002\end{array}$

0.000
0.001

0.000

0,000

0.000
0.000

0.000
0.000

$-0$.

0.000

0.

\begin{tabular}{|c|c|c|c|c|c|c|c|}
\hline 100.0 & $-0: 8$ & $\begin{array}{l}-0 . \\
52.6\end{array}$ & 0.0 & $\begin{array}{l}-0.1 \\
53.2\end{array}$ & $\begin{array}{l}=0, \\
0,3\end{array}$ & $=0.0$ & 100.0 \\
\hline & 100 & 0.0000 & 0.0000 & 0.0135 & 0.0000 & 0.0003 & $0,000 A$ \\
\hline
\end{tabular}

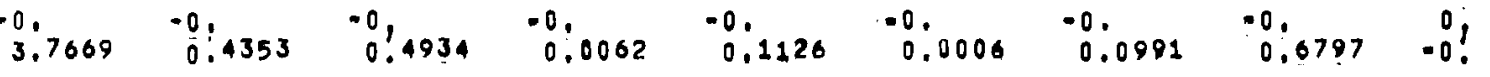

0.

0.0000

0.0000

0.0135

0.000

120.4
18.05
0.0021
407.0
0.

13.9
2.09
0.0002
47.0
0.2
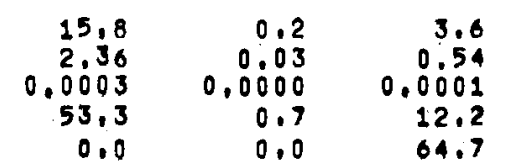

$\begin{array}{rrr}3.2 & 21.7 & 0.9 \\ 0.18 & 3.26 & 00 . \\ 0.0001 & 0.0004 & -0 . \\ 10.7 & 73.4 & -0 \\ 1.3 & 1.8 & 0\end{array}$




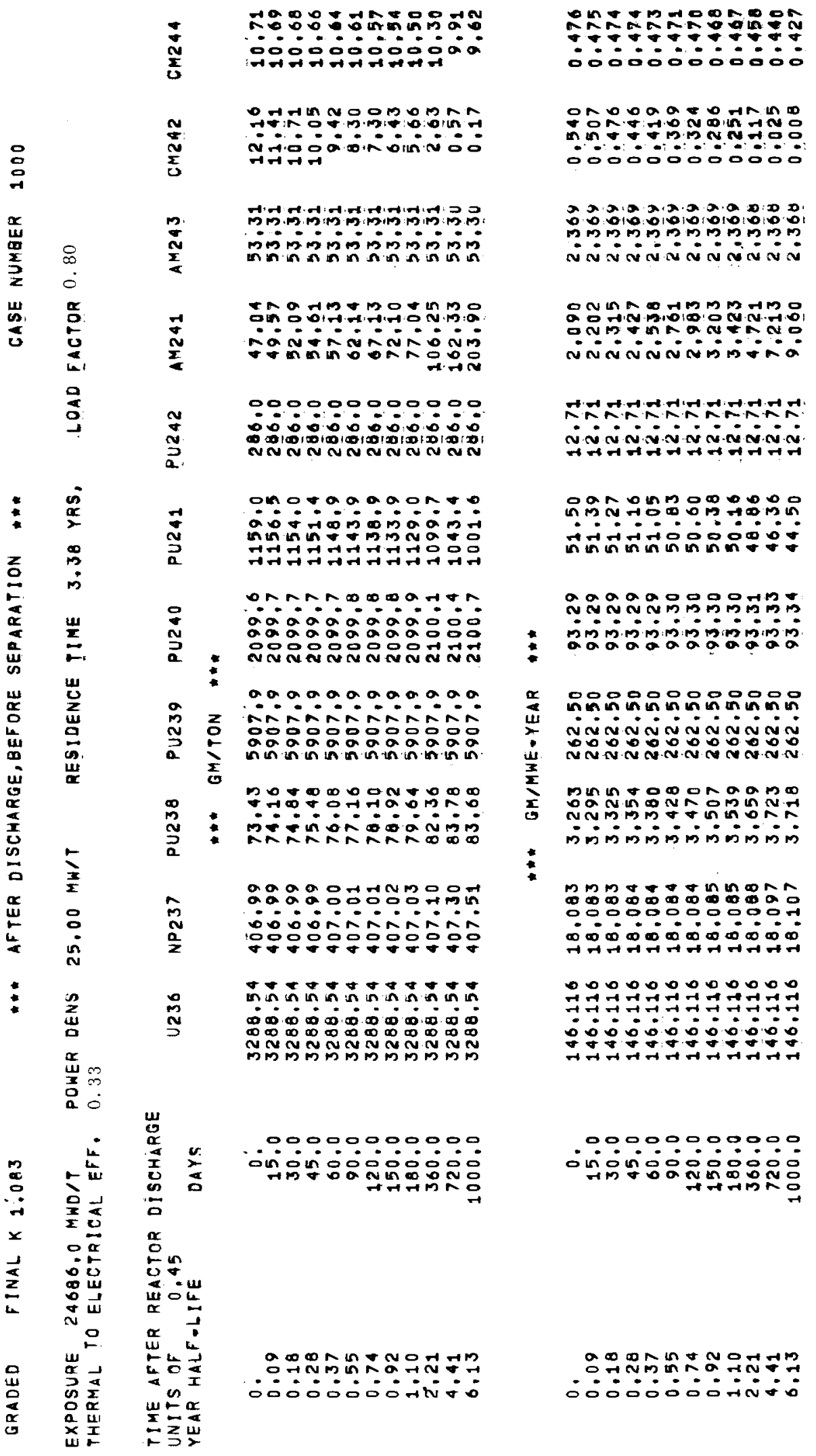




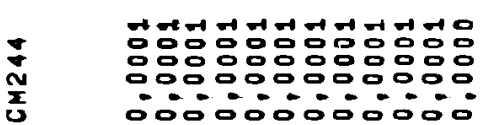

告

$\stackrel{\mathfrak{u}}{\mathfrak{Z}}$

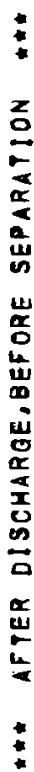

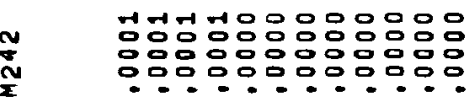

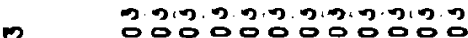

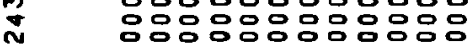

I

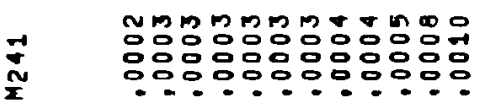

00000000000

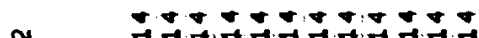

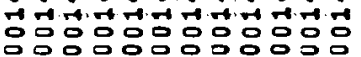

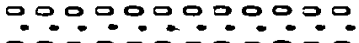

$\stackrel{\square}{\mathfrak{a}}$

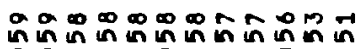

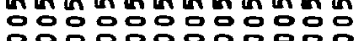

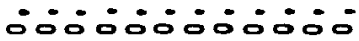

$\stackrel{0}{\stackrel{0}{a}}$

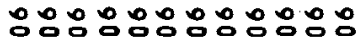

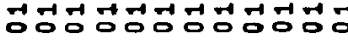
00000000000

$\stackrel{\text { a }}{\stackrel{\text { d }}{3}}$

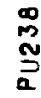

$\underset{n}{n}$

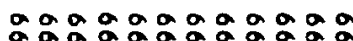

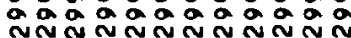

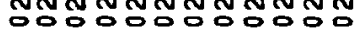

0000000000

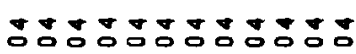

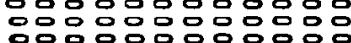

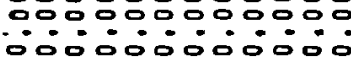

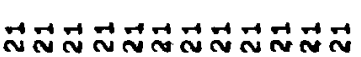

ㅇㅇㅇㅇㅇㅇㅇㅇㅇㅇㅇㅇㅇㅇ응

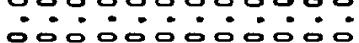

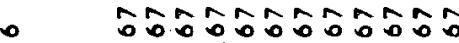
\ ठ000000000

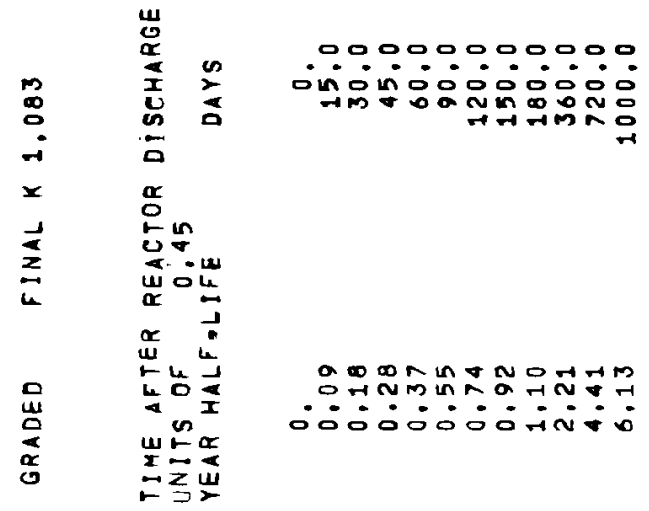

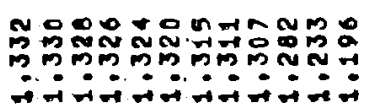

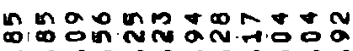

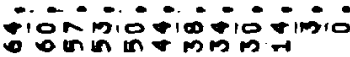

00000000000

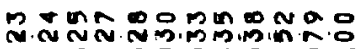

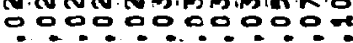
00000000000

تே்ட்ட்

$\therefore 0000000000$

* 00000000000

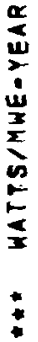

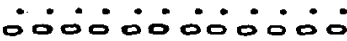

HNNATR NDONOO กา.

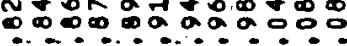

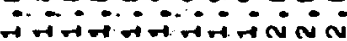

व

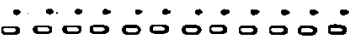

00000000000

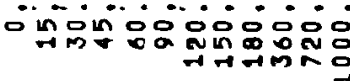

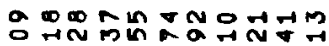
-0000000. 
GRADED FINAL K $1.0 B 3$

TIME AFTER REACTOR DISCHARGE UNITS OF ${ }^{0.45}$ DAYS

$$
\begin{aligned}
& 0.1 \\
& 0.09 \\
& 0.18 \\
& 0.28 \\
& 0.37 \\
& 0.55 \\
& 0.74 \\
& 0.92 \\
& 1.10 \\
& 2.21 \\
& 4.41 \\
& 0.13
\end{aligned}
$$

$0:$

30.0

45,0

60.0

90,0

120.0

\begin{tabular}{|c|c|c|c|c|c|c|c|c|}
\hline $\begin{array}{l}0.77 \\
0.78 \\
0.79 \\
0.79 \\
0.80 \\
0.81 \\
0.82 \\
0.83 \\
0.84 \\
0.87 \\
0.89 \\
0.89\end{array}$ & $\begin{array}{l}62.02 \\
62.03 \\
62.04 \\
62.05 \\
62.07 \\
62.09 \\
62.12 \\
62.14 \\
62.17 \\
62.35 \\
62.71 \\
62.98\end{array}$ & $\begin{array}{l}22.04 \\
22.05 \\
22.05 \\
22.05 \\
22.06 \\
22.07 \\
22.08 \\
22.09 \\
22.10 \\
22.16 \\
22.29 \\
22.40\end{array}$ & $\begin{array}{l}12.17 \\
12.14 \\
12.12 \\
12.09 \\
12.07 \\
12.02 \\
11.98 \\
11.03 \\
11.08 \\
11.01 \\
11.07 \\
10.08\end{array}$ & $\begin{array}{l}3.00 \\
\overline{3} .00 \\
3.00 \\
3.00 \\
\overline{3} .00 \\
\overline{3} .01 \\
\overline{3} .01 \\
3.01 \\
\overline{3} .01 \\
3.02 \\
\overline{3} .02 \\
3.04\end{array}$ & $\begin{array}{l}46.87 \\
48.18 \\
49.42 \\
50.60 \\
51.73 \\
53.82 \\
55.74 \\
57.49 \\
59.10 \\
66.59 \\
75.28 \\
79.28\end{array}$ & $\begin{array}{l}53.10 \\
51.88 \\
50.50 \\
49.40 \\
48.27 \\
46.10 \\
44.26 \\
42.51 \\
40.94 \\
33.41 \\
24.72 \\
20.74\end{array}$ & $\begin{array}{r}53.18 \\
51.63 \\
50,07 \\
40.52 \\
46.97 \\
43.89 \\
40,85 \\
37.89 \\
35.01 \\
20.35 \\
5,44 \\
1.77\end{array}$ & $\begin{array}{l}46.82 \\
48.37 \\
49.93 \\
51.48 \\
53.03 \\
36.11 \\
59.15 \\
62.11 \\
64.99 \\
79.65 \\
94.56 \\
98.23\end{array}$ \\
\hline
\end{tabular}

180.0

360,0

720.0

1000.0 after discharge, before separation

U236 NP237 $\rightarrow$
CASE NUMBER 1000 


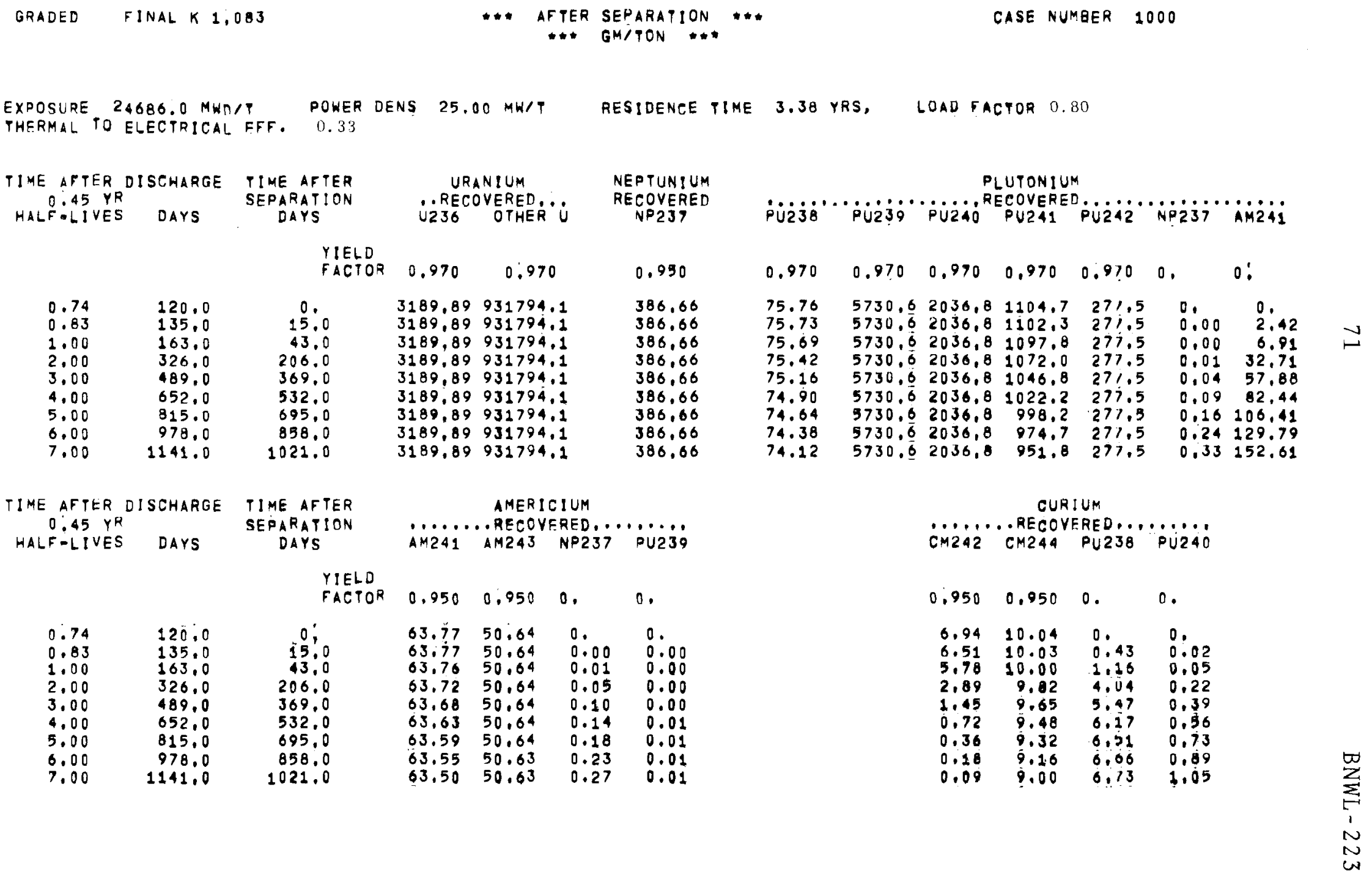




\section{0}

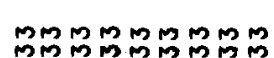

บบ

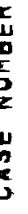

NNNANNNNN

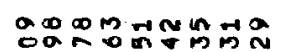

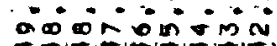

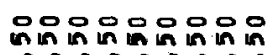
웅영영영영

nN $N$ N N N N N

- a N N

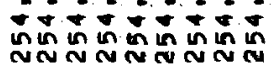

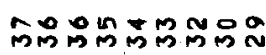

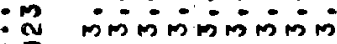

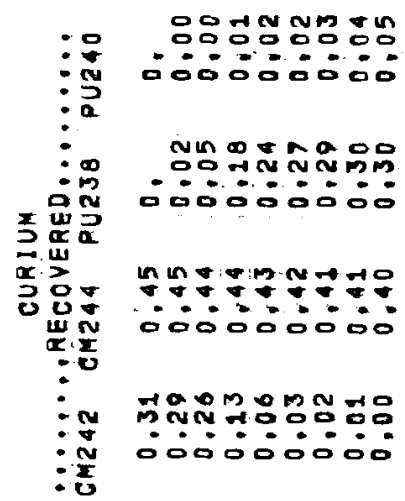

TNY YNTNN

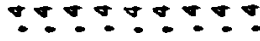

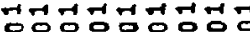

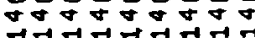

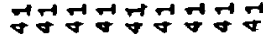

RMRRRRMRR

응명명응

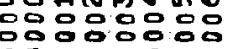

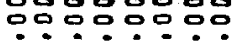
ல்

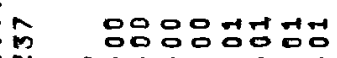

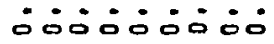

ninin un inin in un

minnivinan

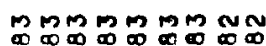

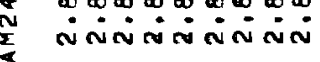

10

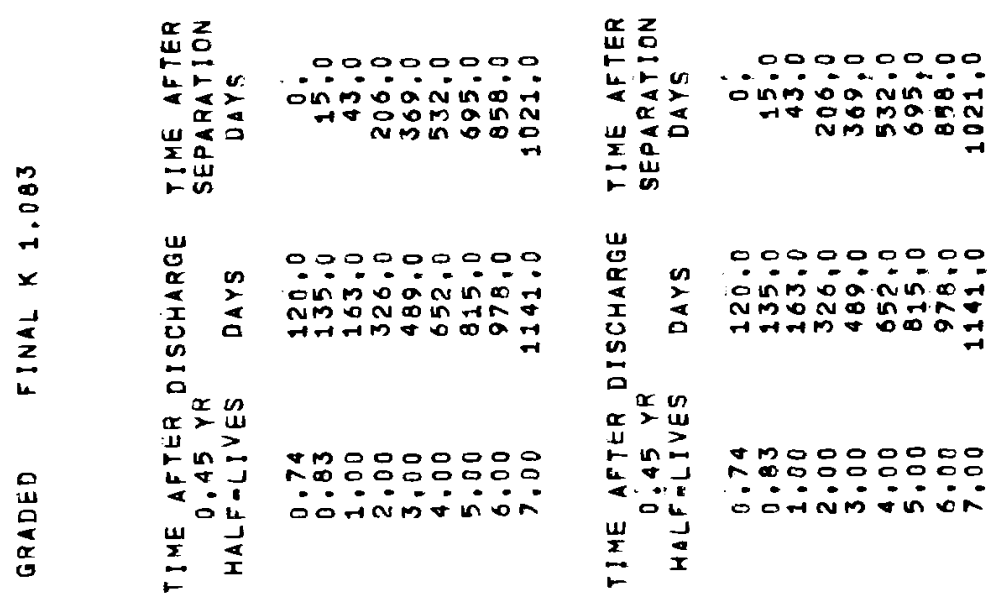




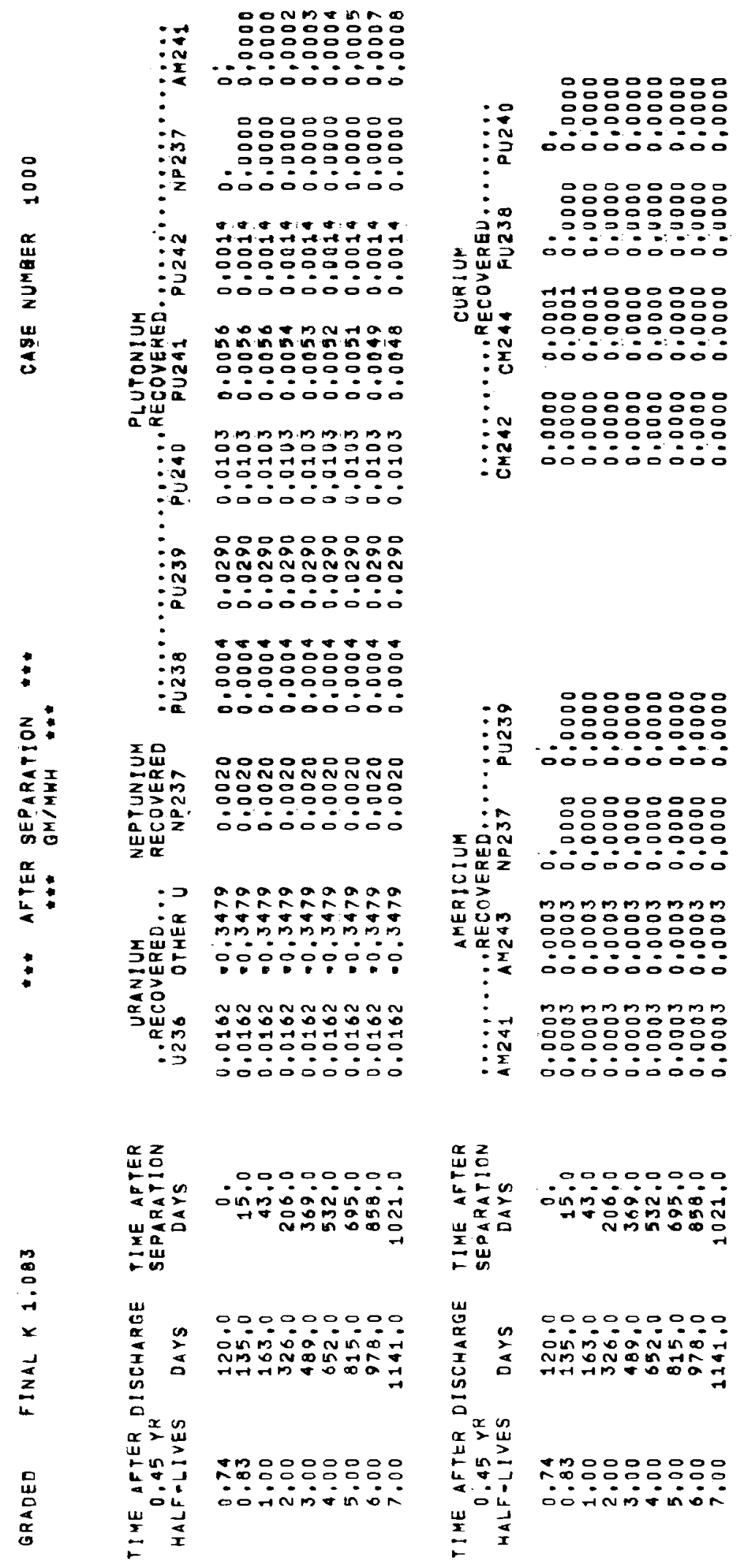




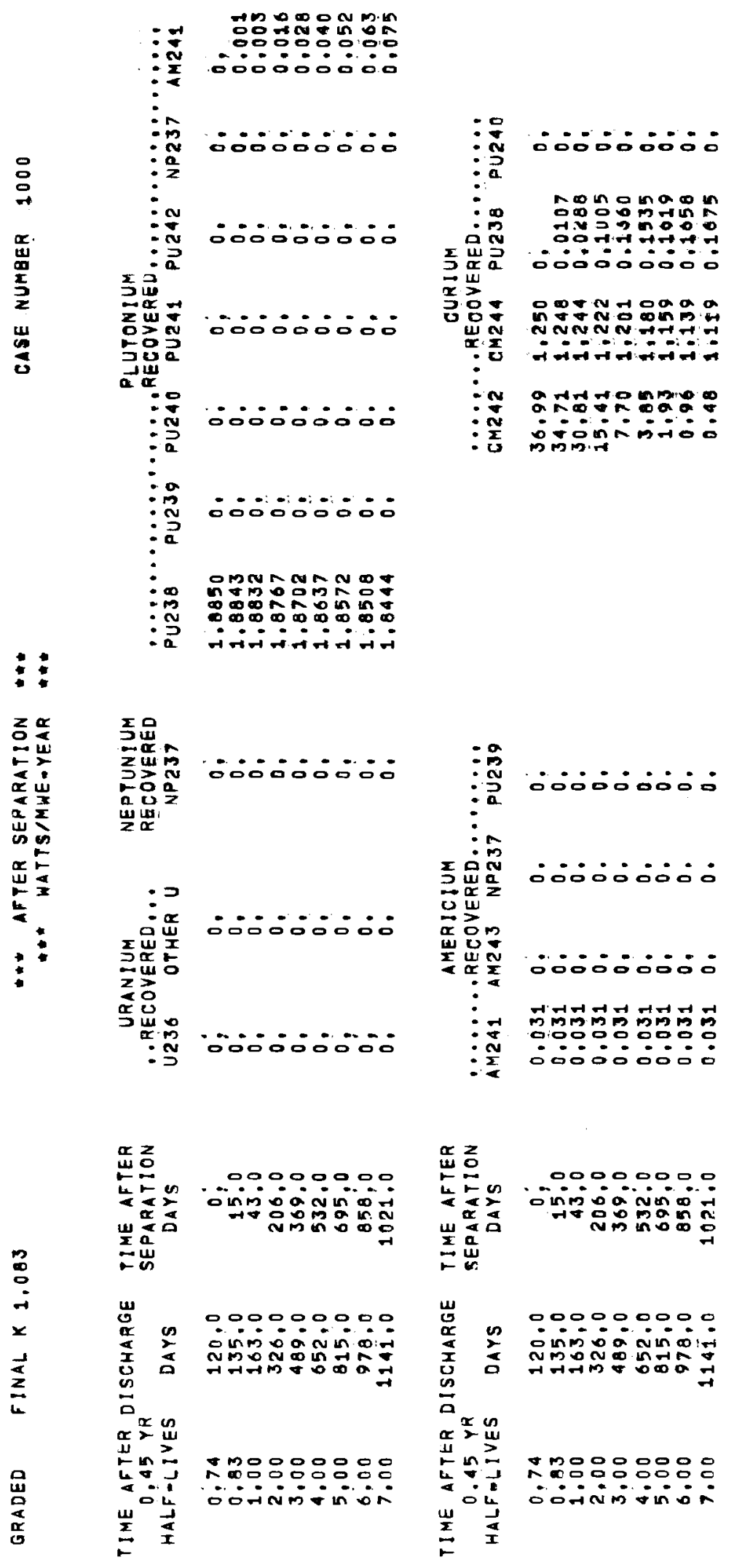


GRADED FINAL K 1.083

\begin{tabular}{|c|c|c|}
\hline $\begin{array}{l}\text { TIME AFTER D } \\
\text { O.45YYR } \\
\text { HALF-LIVES }\end{array}$ & DAYS & $\begin{array}{c}\text { TIME AFTER } \\
\text { SEPARATION } \\
\text { DAYS }\end{array}$ \\
\hline $\begin{array}{l}0.74 \\
0.83 \\
1.00 \\
2.00 \\
3.00 \\
4.00 \\
5.00 \\
6.00 \\
7.00\end{array}$ & $\begin{array}{r}120.0 \\
135.0 \\
163.0 \\
326.0 \\
489.0 \\
652.0 \\
815.0 \\
978.0 \\
1141.0\end{array}$ & $\begin{array}{r}0.0 \\
15.0 \\
43.0 \\
206.0 \\
369.0 \\
532.0 \\
695.0 \\
858.0 \\
1021.0\end{array}$ \\
\hline $\begin{array}{r}\text { TIME AFTER D D } \\
045 \text { YR } \\
\text { HALF LIVES }\end{array}$ & $\begin{array}{l}\text { ISCHARGE } \\
\text { DAYS }\end{array}$ & $\begin{array}{c}\text { TIME AFTER } \\
\text { SEPARATION } \\
\text { DAYS }\end{array}$ \\
\hline $\begin{array}{l}0.74 \\
0.83 \\
1.00 \\
2.00 \\
3.00\end{array}$ & $\begin{array}{l}120.0 \\
135.0 \\
163.0 \\
326.0 \\
489.0\end{array}$ & $\begin{array}{r}0.0 \\
15.0 \\
43.0 \\
206.0 \\
369.0\end{array}$ \\
\hline $\begin{array}{l}4.00 \\
5.00 \\
6.00 \\
7.00\end{array}$ & $\begin{array}{r}652.0 \\
815,0 \\
978.0 \\
1141.0\end{array}$ & $\begin{array}{r}532: 0 \\
605.0 \\
858.0 \\
1021.0\end{array}$ \\
\hline
\end{tabular}

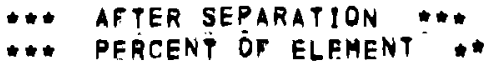

CASE NUMBER $\$ 000$

RECOVIUMD: NEPTUN?UM U236 OTHER'Q

$\begin{array}{lll}0.34 & 99.66 & 100.00 \\ 0.34 & 99.66 & 100.00 \\ 0.34 & 99.66 & 100.00 \\ 0.34 & 99.66 & 100.00 \\ 0.34 & 99.66 & 100.00 \\ 0.34 & 99.66 & 100.00 \\ 0.34 & 99.66 & 100.00 \\ 0.34 & 99.66 & 100.00 \\ 0.34 & 99.66 & 100.00\end{array}$

AMERICIUM

AM2 11 M RECOVERED

$55.74 \quad 44,26 \quad 100.00 \quad 100.00$

$55,74 \quad 44,26100,00100,00$

$55,73 \quad 44,27 \quad 100,00 \quad 100,00$

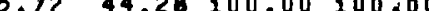

$55,70 \quad 44,30,100,00,100,00$

$55.6944 .31 \quad 100.00 \quad 100.00$

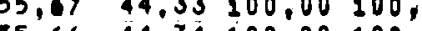

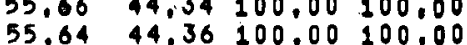

PLUPONIUM

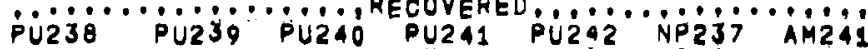

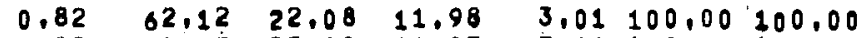

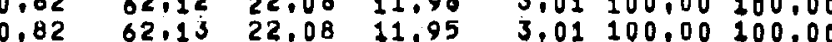

$0.82 \quad 62.17 \quad 22.09$ 11.91 3.01 $100,00100.00$

3.02100 .00100 .00

3.03100 .00100 .00

$0.82 \quad 62.5122 .22 \quad 11.42 \quad 3.03100 .00200 .00$

$3.03100 .00,200.00$

0.82 62.85 $22.3470 .95 \quad 3.04100 .00100 .00$

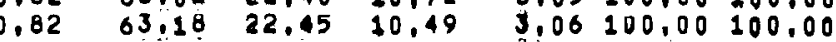

CURIUM

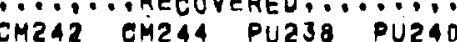

\begin{tabular}{|c|c|c|}
\hline $\begin{array}{r}40.85 \\
39,36 \\
36.63 \\
22.73 \\
13,02 \\
7.08 \\
3,75 \\
1.94\end{array}$ & $\begin{array}{l}59,15 \\
60,64 \\
63,37 \\
77,27 \\
86,98 \\
92,92 \\
90,27 \\
98,06 \\
99,01\end{array}$ & $\begin{array}{r}0 . \\
96: 35 \\
96.15 \\
94.82 \\
93,31 \\
91.68\end{array}$ \\
\hline
\end{tabular}




\section{REFERENCES}

(1) D. E. Deonigi. "Calculation of Production and Pricing of Transuranium Isotopic Heat Sources," ANS Transactions, p. 421. November, 1963

(2) C. A. Rohrmann. Radioisotopic Heat Sources, HW-76323, p. 12, February, 1963 .

(3) A Basic Toxicity Classificatıon of Radionuclides, International Atomic Energy Agency, Vienna, 1963.

(4) V. Keshishian, E. H. Ottewitte, and C. L, Dunford。 "The Criticality of Curium-244," paper presented at ANS Meeting, Washington, D.C., November, 1965 .

(5) E. T. Merri11, ALTHAEA (to be published)

(6) F. P. Roberts, H. H. Van Tuyl. Promethium-146, Fission Product, and Transuranium Isotope Content of Power Reactor Fuels, Comprehensive Chemical Analyses, BNWL-45, March, 1965.

(7) $1000 \mathrm{MW}$ Closed-Cycle Water Reactor Study, WCAP-2385, 2 vols. March, 1963 . (Limited Distribution) Westinghouse E1ectric Corporation, Pittsburg, Pa.

(8) D. E. Deonigi. Formation of Transuranium Isotopes in Power Reactors, BNWL-140 REV1, January, 1966

(9) L. W. Lang. Management of Americium in Power Reactor Fue 1s to Optimize Production of Alpha-Emitting Isotopes, BNWL-SA-472, January, 1966.

(10) E. A. Eschbach, D。E. Deonigi, and S, Goldsmith. QUICK A Simplified Fue1 Cost Code, HW-71812, January, 1962.

(11) E. A. Eschbach. Fuel Cycle Analysis for Successive Plutonium Recycle, HW-7221\%, p。 84, February, 1962 A. F. Rupp, J, A Cox, and F. T. Binford, Radioisotope Production in Power Reactors, ORNL-3792, p. 53, May, 1965 H. H. Van Tuyl. Unpublished Data, (Personal Communication) 
1

1

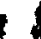

1

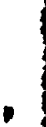




\section{DISTRIBUTION}

\section{Number of Copies}

343
Division of Technical Information Extension

Agricultural Research Service Air Force Flight Dynamics Laboratory Air Reduction Company, Incorporated Airesearch Manufacturing Company Argonne Cancer Research Hospital Armed Forces Institute of Pathology Army Ballistic Missile Agency At1antic Research Nuclear Corporation AEC Division of Isotopes Development Babcock and Wilcox Company (Washington) Brooke Army Medical Center Bureau of Commercial Fisheries Bureau of Commercial Fisheries, Seattle Bureau of Mines, Bartlesville Bureau of Mines, Washington Bureau of Reclamation Business and Defense Services Administration Catholic University of America Colorado School of Mines Columbia University (Leonard) Consolidation Coal Company Division of Reactor Development, AEC Washington, D. C. Electric Utilities Company Ford (Edse1 B.) Institute

Forest Service

Frankford Arsenal General Electric, Richland (GETA File Copies)

General Electric Company, San Jose (Trumbu11)

Georgia Institute of Technology Gorton's of Gloucester, Inc. Hazleton Nuclear Science Corporation Hercules Powder Company High Voltage Engineering Corporation Hughes Research Laboratories IIT Research Institute (Reiffel) Internal Revenue Service ISo/Serve, Inc. Johnston (Willian $\mathrm{H}_{\text {. }}$ ) Laboratories, Inc. Lamont Geological Observatory Lane-We11s 


\section{DISTRIBUTION (Contd.)}

\section{Number of Copies}

Library of Congress

Little (Arthur D.), Inc.

Louisana State University

Maxield Clinic Hospital

Melpar, Inc.

Minnesota Mining and Manufacturing Company

Monsanto Research Corporation

NASA Goddard Space Flight Center

National Agricultural Library

National Bureau of Standards (Koch)

National Institutes of Health

Naval Propellant Plant

New York University (Prince)

North Carolina State College

Nuclear-Chicago Corporation

Nuclear Research Corporation

Nuclear Science and Engineering Corporation

Ohio State University

Oregon State University

Parametrics, Inc.

Picker X-Ray Corporation

Processing Equipment Corporation

Public Health Service, Las Vegas

Public Health Service, Montgomery

Radiation Applications, Incorporated

Radio Corporation of America

Research Analysis Corporation

Research Triangle Institute

Richland Operations office R. K. Sharp

Technical Information Library

P. G. Holsted (2)

Sharp Laboratories Division

Southern Interstate Nuclear Board

Spindletop Research Center

Swift and Company

Technical Operations, Inc.

Texas A\&M University

Texas Nuclear Corporation

Tracer $1 \mathrm{ab}$

Tracerlab, Richmond

Underwriters Laboratories, Inc.

Union Carbide Corporation (Tuxedo)

Universai Match Corporation

University of California, Davis (Maxie)

University of California, Livermore Attn: Dr. James Hadley 


\section{DISTRIBUTION (Contd.)}

Number of Copies

1
1
1
1
1
1
1

University of Florida (Dennison)

University of Hawaii (Ross)

University of Maryland

Vitro Engineering Company

Washington State University

West Virginia University

Western Nuclear Corporation

126

Battelle-Northwest

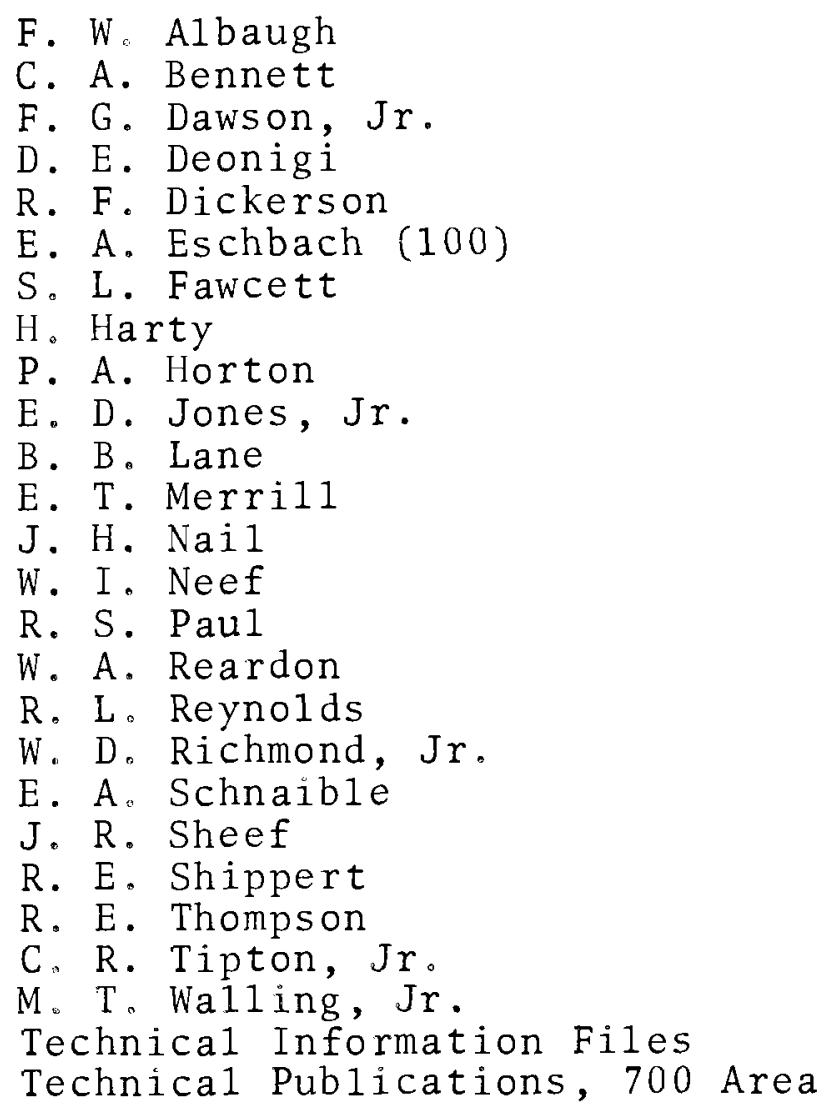


